BNL 30222

\title{
A SUBCHRONIC INHALATION STUDY OF FISCHER 344 RATS EXPOSED TO 0, 0.4, 1.4 or 4.0 ppm ACROLEIN
}

\author{
Prepared by \\ RAYMOND S. KUTZMAN \\ MEDICAL DEPARTMENT \\ BROOKHAVEN NATIONAL LABORATORY \\ UPTON, NEW YORK 11973
}

\begin{abstract}
for
THE NATIONAL TOXICOLOGY PROGRAM

under

INTERAGENCY AGREEMENT NUMBER
\end{abstract}

222-Y01-ES-9-0043

October 1981 
A SUBCHRONIC INHALATION STUDY OF FISCHER 344 RATS EXPOSED TO $0,0.4,1.4$, or 4.0 PPM ACROLEIN

Conducted at The Medical Department

of

Brookhaven National Laboratory

for

The National Toxicology Program

under

Interagency Agreement Number

222-YO1-ES-9-0043

Report Prepared by

Ray S. Kutzman

October 1981 


\title{
A SUBCHRONIC INHALATION STUDY OF FISCHER 344 RATS EXPOSED TO $0,0.4,1.4$, or 4.0 PPM ACROLEIN
}

\author{
Principal Investigator: \\ Robert T. Drew, Ph.D. \\ Program Manager: \\ Raymond S. Kutzman, Ph.D. \\ Respiratory Phystologist: \\ Daniel L. Costa, Sc.D. \\ Pathologist: \\ Beverly $¥$. CockreIl, D.V.M., Ph.D.* \\ Biochemist: \\ Edwin A. Popenoe, Ph.D. \\ Cytogeneticist: \\ Raymond R. Tice, Ph.D. \\ Reproductive Physiologist: \\ Arland I. Carsten, Ph.D. \\ *Experimental Pathology Laboratories, Inc. \\ Herndon, Virginia.
}




\section{ACKNOWLEDGEMENTS}

The authors wish to thank William Maston and Peter Bonti for chamber operation and animal care. The technical assistance of James Lehmann and Elizabeth Jellett for pulmonary function testing; Martine 0 'Connor for necropsy; Max Schmaeler for biochemistry; Michael Torelli for reproductive studies; and Thomas Vogt for cytology is most appreciated. Thanks are extended to Charles Bores, computer programmer and Patricia Hu, biometrician. We thank Dr. Robert Wehner for the follow-up pathology observations presented in Appendix H. Our appreciation is also extended to Jayne Cutt for secretarial services. Special thanks are extended to Dr. Sonja Haber for her review of this document. 
List of Tables..... . . . . . . . . . . . . . . . . .

List of Figures . . . . . . . . . . . . . . . . . . . . . . . iii

List of Appendices . . . . . . . . . . . . . . . . . . . . . . . . iv

List of Abbreviations . . . . . . . . . . . . . . . . . . . . v

SUMMARY . . . . . . . . . . . . . . . . . . . . . . . . . 1

INTRODUCTION . . . . . . . . . . . . . . . . . . . . . . . . . 4

MATERIALS AND METHODS . . . . . . . . . . . . . . . . . . . 6

Animal Procedures and Exposures . . . . . . . . . . . . . 6

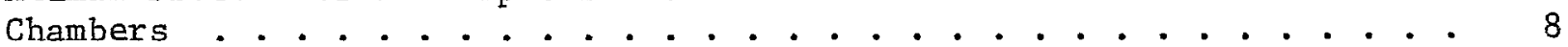

Acrolein Generation . . . . . . . . . . . . . . . . . . . . . 9

Monitoring of Acrolein Concentrations . . . . . . . . . . . . . . . . . 9

Necropsy of Moribund and Dead Animals . . . . . . . . . . . . . . . . 9

Respiratory Physiology . . . . . . . . . . . . . . . 10

Pathological Examination . . . . . . . . . . . . . . . . . 16

Determination of Lung Composition . . . . . . . . . . . . . . . . 18

Cytological Methods . . . . . . . . . . . . . . . . . . . . 18

Reproductive Potential Methods . . . . . . . . . . . . . . 20

Statistical Methods... . . . . . . . . . . . . . . . 21

RESULTS . . . . . . . . . . . . . . . . . . . . . . . 24

General Toxicology Parameters . . . . . . . . . . . . . . . . 24

Exposure Conditions . . . . . . . . . . . . . . . . . . . . . 24

Animal Mortality . . . . . . . . . . . . . . . . . . . 24

Animal Weights . . . . . . . . . . . . . . . . . . . . 24

Organ Weight and Organ-to-Body Weight Ratios . . . . . . . . . . 25

Respiratory Physiology . . . . . . . . . . . . . . . . . 37

Parameters of Spontaneous Breathing. . . . . . . . . . . . . . . 37

Heart Rate . . . . . . . . . . . . . . . . . . . 37

Lung Volumes . . . . . . . . . . . . . . . . . . . . . 38

"Parenchymal" Behavior and DLCO . . . . . . . . . . . . . . . . 39

Distribution of Ventilation . . . . . . . . . . . . . . . . . 39

Flow Volume Dynamics . . . . . . . . . . . . . . . . . 40

Pathology Data . . . . . . . . . . . . . . . . . . . . 57

Dead and Moribund Animals . . . . . . . . . . . . . . . 57

Pathology Animals . . . . . . . . . . . . . . . . . . 57

Respiratory Physiology Animals . . . . . . . . . . . . . 58

Lung Composition Data . . . . . . . . . . . . . . . . . . . . 77

Lung Weight and Water Content . . . . . . . . . . . . . . . 77

Lung DNA . . . . . . . . . . . . . . . . . . . . . 77

Lung Protein . . . . . . . . . . . . . . . . . . 78

Lung Elastin . . . . . . . . . . . . . . . . . . . 78

Lung Collagen . . . . . . . . . . . . . . . . . . 78 
Cytology Results . . . . . . . . . . . . . . . . . . . . 84

Bone Marrow . . . . . . . . . . . . . . . . . . . . . 84

Peripheral Blood Lymphocytes . . . . . . . . . . . . . . . . 84

Lung Alveolar Macrophages . . . . . . . . . . . . . . . . 85

Sperm Morphology . . . . . . . . . . . . . . . . . . . . 85

Reproductive Potential Studies . . . . . . . . . . . . . . . . . . 91

Statistical Relationships Among Data . . . . . . . . . . . . . . . . 94

Correlation Analysis . . . . . . . . . . . . . . . . . . . 94

Discriminant Analysis . . . . . . . . . . . . . . . . . 95

DISCUSSION . . . . . . . . . . . . . . . . . . . . . 106

REFERENCES . . . . . . . . . . . . . . . . . . . . . . . 115 


\section{LIST OF TABLES}

Table 1: Daily Mean Chamber Concentrations of Acrolein . . . . . 28-30

Table 2: Absolute Organ Weights and Body Weights . . . . . . . . . 34

Table 3: Organ-to-Body Weight Ratios . . . . . . . . . . . 35

Table 4: Lung Weights and Lung-to-Body Weight Ratios in

Rats from Respiratory Physiology Studies..... .

Table 5: Parameters of Spontaneous Breathing . . . . . . . . . . 42

Table 6: Ánalysis of Electrocardiogram Time Intervals . . . . . . 44

Table 7: Indices of Parenchymal Damage . . . . . . . . . . . . 49

Table 8: Moment Analysis of Multibreath N2 Washout . . . . . . . 52

Table 9: Statistical Analysis of Normalized Data Points on MEFV Curves................... 54

Table 10: Analysis of Upstream Airway Resistance . . . . . . . . . 56

Table 11: Pathological Findings in Control and Acrolein-Exposed

Rats................. 61-66

Table 12: Pathological Findings in the Respiratory Tissues of

Control and Acrolein-Exposed Rats Subjected to

Pulmonary Function Tests . . . . . . . . 67-74

Table 13: Pulmonary Pathology Scores of Rats which Completed

Respiratory Physiology Tests... . . . . . . 75

Table 14: Body Weight, Lung Weight, and Lung Water Content . • . 79

Table 15: Lung DNA . . . . . . . . . . . . . . . . 80

Table 16: Lung Protein . . . . . . . . . . . . . . . . 81

Table 17: Lung Elastin . . . . . . . . . . . . . . . 82

Table 18: Lung Hydroxyproline . . . . . . . . . . . . . . . 83

Table 19: Frequency of Sister Chromatid Exchange and Rates of Cell

Proliferation in Bone Marrow Cells . . . . . . 86-87

Table 20: Frequency of Sister Chromatid Exchange and Rates of Cell

Proliferation in Peripheral Blood Lymphocytes . . . 88-89

Table 21: Chromosomal Aberration Frequencies in Peripheral Blood

Lymphocytes . . . . . . . . . . . . . . . 
Table 22: Reproductive Fitness of Control and Acrolein-Exposed Male Rats... . . . . . . . . . . . .

Table 23: Reproductive fitness of Control and Acrolein Exposed Female Rats...................

Table 24: List of Variables Used in Pearson and Spearman Correlations and Discriminant Analysis of Pulmonary Function, Lung Composition, and Pathology Data . . .

Table 25: Pearson Correlation Coefficients and Spearman Rank Correlation Coefficients Among Pulmonary Data . . .99-102

Table 26: Categorization of Rats Exposed to $0.0,0.4,1.4$, or 4.0 ppm Acrolein by a Classification Function Derived from the Discriminant Variables Defined by Stepwise Discriminant Analysis . . . . . . . . . . . 103

Table 27: Categorization of Rats Exposed to $0.0,0.4$, or $1.4 \mathrm{ppm}$ Acrolein by a Classification Function Derived from the Discriminant Variables Defined by Stepwise Discriminant Analysis... . . . . . . . .

Table 28: Discriminant Variable and Classification of Animals Resulting from Analysis of Selected Data Sets of Rats Exposed to $0.0,0.4$, or $1.4 \mathrm{ppm}$ Acrolein... . 
Figure 1: Schematic diagram of rodent plethysmograph . . . . . . . . 11

Figure 2: Linear regression calibration plot for MIRAN 80-A

Figure 3: Mortality of male rats exposed to $4.0 \mathrm{ppm}$ acrolein . . . 31

Figure 4. Weight changes of male Fischer 344 rats . . . . . . . . . 32

Figure 5: Weight changes of female Fischer 344 rats . . . . . . . . 33

Figure 6: Pulmonary resistance and dynamic compliance normalized
to the functional reserve capacity . . . . . . . . . 43

Figure 7: Representative electrocardiograms . . . . . . . . . . 45

Figure 8: Trapped air in the lungs of control and acrolein-exposed

rats..................... 46

Figure 9: Divisions of lung volumes . . . . . . . . . . . . . 47

Figure 10: Normalized lung volumes . . . . . . . . . . . . . . . 48

Figure 11: Quasi-static compliance . . . . . . . . . . . . 50

Figure 12: Quasi-static compliance as a function of vital
capacity . . . . . . . . . . . . . . . . 51

Figure 13: Multibreath $\mathrm{N}_{2}$ washout curves . . . . . . . . . . . 53

Figure 14: Maximum expiratory flow volume curves . . . . . . . . 55

Figure 15: Frequency of pulmonary pathology scores . . . . . . . . . 76 


\section{LIST OF APPENDICES}

Appendix A: Acrolein: Chemical and Physical Information . . . . . A-1

Appendix B: Chemical Method for Analysis of Chamber Acrolein

Concentration . . . . . . . . . . . . . . B-1

Appendix C: List of Exposure Days on which Wet Chemical

Determinations of Chamber Concentrations were

Conducted . . . . . . . . . . . . . . . . . C-1

Appendix D: Photocopies of Chamber Data Sheets for Four Randomly

Selected Exposure Days . . . . . . . . . . . D-1

Appendix E: Pulmonary Function Data from Individual Fischer 344

Rats... . . . . . . . . . . . . . E-1

Appendix F: Lung Composition Data from Individual Fischer 344

Rats... . . . . . . . . . . . . . . F-1

Appendix G: Abnormal Sperm Data from Individual Fischer 344

Rats . . . . . . . . . . . . . . . G G-1

Appendix H: Canonical Analysis Plots of Pulmonary Data From

Fischer 344 Rats Exposed to Acrolein . . . . . . . . . H-I

Appendix I: Follow-up Pulmonary Histopathology on Rats Maintained under Non-SPF Conditions for Ten Weeks After Six Day Post-Exposure Recovery Period . . . . . . . . . . . . I-1 


\section{LIST OF ABBREVIATIONS}

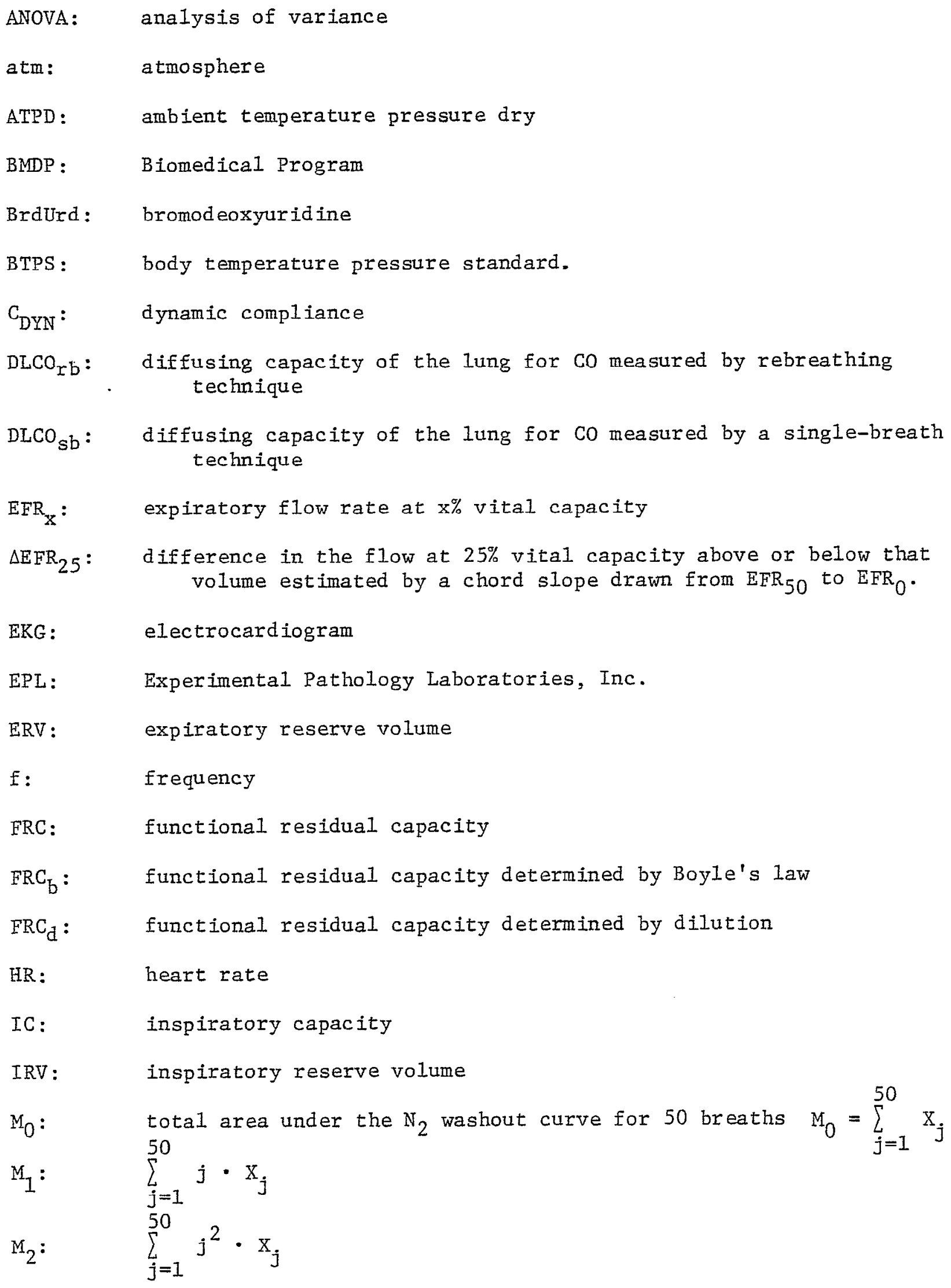




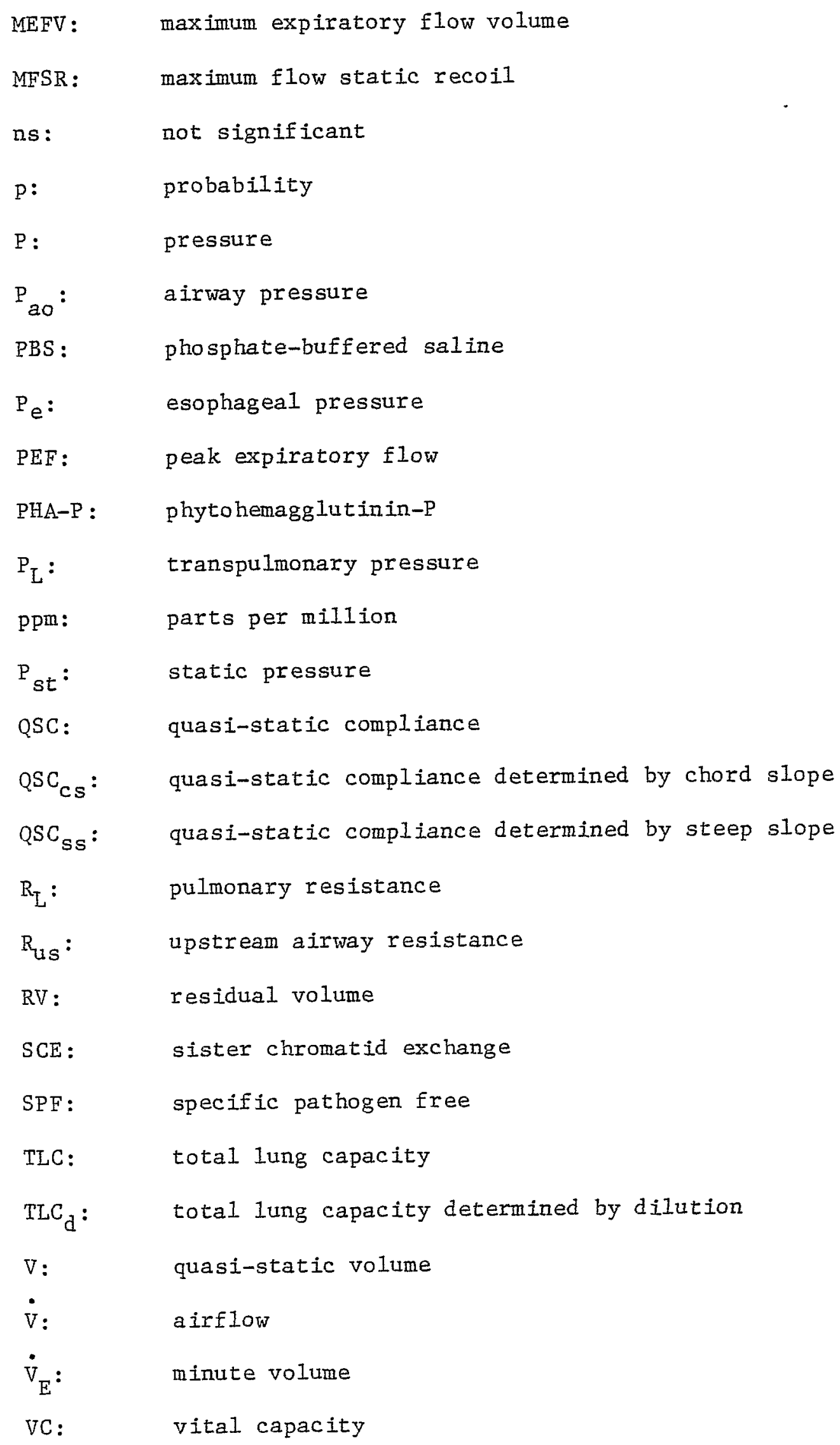


$\mathrm{V}_{\mathrm{T}}: \quad$ tidal volume

$\mathrm{V}_{\mathrm{TG}}: \quad$ trapped gas 
SUMMARY

Fischer 344 rats were exposed to $0.0,0.4,1.4$, or $4.0 \mathrm{ppm}$ acrolein for 62 days. The major objective of the study was to relate the results of a series of pulmonary function tests to biochemical and pathological alterations observed in the lung. Cytological and reproductive potential endpoints were also assessed after acrolein exposure.

Rats were exposed to acrolein for 6 hours/day, 5 days/week for 62 days. Mortality was observed only in the $4.0 \mathrm{ppm}$ chamber where 32 of 57 exposed males died; however, none of the 8 exposed females died. Most of the mortality occurred within the first 10 exposure days. Histologic examination indicated that the animals died of acute bronchopneumonia. The surviving males and females exposed to $4.0 \mathrm{ppm}$ acrolein gained weight at a significantly slower rate than control animals. The growth of both sexes in the 0.4 and $1.4 \mathrm{ppm}$ groups was similar to that of their respective controls.

Histopathologic examination of animals after 62 days of exposure revealed bronchiolar epithelial necrosis and sloughing, bronchiolar edema with macrophages, and focal pulmonary edema in the $4.0 \mathrm{ppm}$ :group. These lesions were, in some cases, associated with edema of the trachea and peribronchial lymph nodes, and acute rhinitis which indicated an upper respiratory tract effect of acrolein. Of particular interest was the variability of response between rats in the $4.0 \mathrm{ppm}$ group, some not affected at all while others were moderately affected. Intragroup variability in toxicity was also apparent in the $1.4 \mathrm{ppm}$ exposure group where only 3 of 31 animals examined had lesions directly related to acrolein exposure. Extra respiratory organs appeared unaffected.

Pulmonary physiology tests revealed a substantial decrement in the pulmonary function of rats exposed to $4.0 \mathrm{ppm}$ acrolein. The pattern observed suggested obstructive lung disease with virtually every static and dynamic 
parameter significantly affected. A depressed flow-volume effort, a leftward shift of the quasi-static compliance curve, and an enlarged lung volume were all consistent with a classical obstructive lesion. While the pulmonary function of the $4.0 \mathrm{ppm}$ group suggested an obstructive lesion, the data from the $0.4 \mathrm{ppm}$ group indicated a restrictive lung lesion. The parameters of spontaneous breathing, and the divisions of lung volume were unremarkable in the low dose group, however, the flow volume maneuver exhibited "supra-normal" flows. This could have resulted from more rigid airways without parenchymal damage. The pulmonary function of the 1.4 ppm exposure group was between that of the low and high dose groups and was nearly identical to that of control animals. These data suggested the development of two functional lesions exhibiting opposing effects on the pulmonary functionmeasurements. It should be noted that the lesion manifesting itself in animals exposed to $0.4 \mathrm{ppm}$ acrolein was not morphologically evident upon histopathologic examination.

The lungs of rats exposed to $4.0 \mathrm{ppm}$ acrolein were heavier than those of the larger control rats. A $20 \%$ increase in the dry weight was accompanied by a $1.5 \%$ increase in water content. This increased dry weight and the absence of a significant change in the amount of DNA and protein per unit dry weight indicated that the increased lung weight of this group was at least in part due to increased cellularity. Lung connective tissue content increased as a result of acrolein exposure. Elastin concentration in the lungs of the 4.0 ppm animals was twice that of control animals. Elastin content of the lungs from the 0.4 and the $1.4 \mathrm{ppm}$ exposed animals was similar to that of the control group. Hydroxyproline (an index of collagen content) concentrations increased significantly in both the intermediate and high dose groups. When based on dry weight the hydroxyproline concentrations of the 1.4 and $4.0 \mathrm{ppm}$ groups were $111 \%$ and $133 \%$, respectively, of control levels. 
The cytological endpoints assessed included sister chromatid exchanges and cell proliferation kinetics in bone marrow cells and peripheral blood Iymphocytes. The incidence of chromosomal aberrations was also examined in peripheral blood lymphocytes. No statistically significant changes were found among these parameters.

The sperm of exposed animals was examined for morphologic abnormalities but none were evident and the percentage of morphologically abnormal sperm was similar in control and acrolein exposed animals. The reproductive potential of male and female Fischer 344 rats was unaffected by acrolein exposure. 


\section{INTRODUCTION}

In recent years the technology has been developed to measure several indices of pulmonary function in rodents. These include: static lung volumes, static and dynamic lung properties, assessment of diffusion capacity, and the distribution of ventilation. Standard toxicity evaluations of airborne materials rarely include assessment of pulmonary function, in part because the applicability of these measurements in the assessment of pulmonary toxicity remains to be demonstrated. In the past, respiratory function tests were generally not as sensitive an index of pulmonary damage as morphologic examination. However, it should be determined whether the recent developments have increased the sensitivity of rodent pulmonary tests. The relative sensitivity of the two indices should be examined so that the cost-benefit ratio of incorporating pulmonary assessment into inhalation toxicology protocols can be evaluated.

The major purpose of this study was to compare the morphological, biochemical, and functional changes induced by exposure to acrolein. This aliphatic aldehyde is a strong cytotoxic and ciliostatic agent (1-3), and its irritating effect on mucus membranes and its acute inhalation toxicity properties have been reported (4-7). Acrolein causes broncho-constriction in guinea pigs (8) and reduced pulmonary compliance in mice (9); therefore, it was an appropriate agent for these studies which were designed to relate pulmonary function to associated pathology and changes in structural components of the lung.

The exposure chambers employed in these studies housed more animals than needed for pathological, physiological, and biochemical assessment; therefore, several other endpoints were investigated. The genetic effects of acrolein exposure were assessed with an assortment of interrelated 
cytogenetic endpoints. Acrolein has been reported to cause impairment of DNA replication in vitro (10). In addition, sperm morphology studies were conducted and the reproductive potential of both male and female exposed rats was assessed. 
MATERIALS AND METHODS

Animal Procedures and Exposures

The Fischer 344 rats used in this study were obtained from Charles River Laboratories, Inc. (Kingston, N.Y.). The animals were received in two shipments and housed in our SPF (specific pathogen free) facility for approximately four weeks before exposure. During this quarantine period, $10 / 200$ and $9 / 185$ rats from the first and second shipments, respectively, were sent to AnMed Laboratories, Inc. (New Hyde Park, N.Y.) for health assessment. This service included: determination of serum viral antibody status (Sendai Virus, Pneumonia Virus of mice, Reo Virus Type 3, Theiler's Virus, Kilham's Rat Virus, Lymphocytic Chorimeningitis, and Rat Chronona Virus); culture of nasoturbinate washings to check for respiratory bacterial pathogens and mycoplasma; oropharyngeal swab for detection of pseudomonas and klebsiella; preparation of fecal samples for bacterial pathogen and parasite detection; preparation of ideal wet mounts for protozoans; inspection of the colon for helminths and of the bladder for Trichosomoides crossicauda; and scanning of the pelt for ectoparasites. Slides for histopathological examination were prepared from the lung, liver, kidney, ileum, spleen, and thymus. Citrobacter freundii was found in the feces and upper respiratory tract of all animals from both shipments. This organism has not been reported as pathogenic in rats; however, it is associated with colonic hyperplasia and diarrhea in laboratory mice (11). Although $\mathrm{C}$. freundii was an unusual and undesirable finding in these animals, its presence was interpreted as not interfering with the use of these animals in the proposed protocol.

During the holding period the rats were ranked by weight and randomly assigned to a particular exposure group. All of the animals were neck tagged to provide permanent identification. The animals were individually 
housed in stainless steel wire mesh cages and provided a standard laboratory diet (Purina Chow) and water ad 1ibitum. A 12-hour-on/12-hour-off 1ight cycle was maintained in the animal room.

Experimental and control animals were placed into the appropriate chambers the night before the initial exposure. Caging and light cycle in the chambers were identical to those in the holding rooms. The cage units (each holding 8 rats, 2 rows of 4) were arranged in 3 tiers with 3 units per tier. Once placed into the chambers, the rats were housed there for 24 hours/ day. Water was supplied to the chamber animals ad libitum; however, the food was removed during the daily 6 hour exposure period. Each animal was weighed after the first exposure day and then weekly according to the following schedule: control rats, Mondays; 0.4 ppm rats, Tuesdays, 1.4 ppm rats, Wednesdays; and 4.0 ppm rats, Thursdays.

The animals were briefly examined each day prior to exposure, when the food troughs were removed and clean catch pans were provided, and again when the food troughs were replaced following the exposure period. The animals were also inspected once daily on weekends. When the animals were weighed they were examined more closely and provided a clean cage. The cage packs were rotated through nine positions ( 3 tiers with 3 units/tier) by moving each pack one position after the weekly weighing.

Rats were exposed to either filtered air, $0.4 \mathrm{ppm}, 1.4 \mathrm{ppm}$, or $4.0 \mathrm{ppm}$ acrolein for six hours/day, five days/week. Each animal was exposed for 62 consecutive days with exceptions only for weekends. Each rat was exposed a minimum of two days the first and final weeks of exposure. In cases where the end-point test procedures were time consuming, the starting dates were staggered while still adhering to the 62 exposure day regime and the minimum number of exposure days per week. With the exception of the rats 
designated for cytology studies, rats were placed into SPF animal rooms for six days after the final exposure. Cytological endpoints were assessed the day after the final exposure.

Animals in the chambers were utilized as follows: Twenty-four animals were placed into each of the four chambers for respiratory physiology studies. After pulmonary function testing, these animals were sacrificed and the lungs carefully removed. The right lung of each animal was submitted for biochemical analysis and the left lung was processed for pathological examination (see Pathologic Examination). Eight rats in each chamber were designated for pathology only. Ten animals from each exposure level were designated for various cytological studies. Eight male and eight female rats were exposed for reproductive studies. The high mortality rate among male rats in the $4.0 \mathrm{ppm}$ exposure chamber reduced the sample size of the high dose group in most studies.

\section{Chambers}

Exposures were carried out in stainless steel and Lucite chambers. Airflow through the $5 \mathrm{~m}^{3}$ chambers was $1 \mathrm{~m}^{3} / \mathrm{min}$. Exhaust air from each chamber was passed through a trap containing activated charcoal before being discharged. The relative humidity was continuously monitored by placing a Honeywell (Model $612 \times 9-\mathrm{HT}$ ) humidity recorder into the control chamber. During the exposure periods, the temperature at several locations in each chamber was monitored with thermocouples wired to a Fluke Datalogger. During nonexposure hours the temperature of the control chamber was recorded on the Honeywell instrument used to record relative humidity. 
Acrolein Generation

Gaseous acrolein (for chemical and physical characteristics see Appendix A) was purchased as an analyzed 1000 ppm mixture in nitrogen (Union Carbide Corporation and Scientific Gas Products, Inc.). The gas mixture regulated to 6 psig was delivered to a glass reservoir from which it was metered via valved rotometers into the air supply lines of the exposure chambers. The glass reservoir was also fitted with a pressure gauge and another valved rotometer by which excess gas was bled off. This discharge system provided greater independent control of the rotometers for the individual chambers. Excess gas released from the reservoir was passed through an activated charcoal trap before discharge into the chamber exhaust system.

Monitoring of Acrolein Concentrations

The acrolein concentration of each chamber was automatically monitored for five minutes every half hour with a Miran infrared analyzer (Model $80 \mathrm{~A}$, Foxboro). The absorbance readings were converted to ppm values using linear regression calibration plots established with chemical analysis techniques for acrolein (12) (Appendix B). The acrolein concentration in each chamber was chemically determined at least bi-weekly (with only two exceptions, Appendix C). Miran absorbance data corresponding to the three most recent chemical determinations for each of the chambers were used to establish a current linear regression plot. The chambers were automatically sampled and the data recorded hourly. After the first $1 / 2$ hour of operation, the data were used to adjust chamber concentrations and calculate mean daily concentrations.

Necropsy of Moribund and Dead Animals

Rats found in a moribund condition were killed with a lethal dose of 
pentabarbitol and exsanguinated via the descending aorta. The lungs of killed and dead animals were removed, the heart, thymus, and excess tissue were trimmed away and the lungs were weighed. The lungs were then fixed with $2.5 \%$ glutaraldehyde in Sorenson's buffer via the trachea at $25 \mathrm{~cm}$ water pressure for 30 minutes. After tracheal fixation, the lungs remained in glutaraldehyde fixative for a minimum of 24 and a maximum of 72 hours. The lungs were then rinsed with four changes of Sorenson's buffer over a 24 hour period and stored in this buffer until prepared for sectioning by Experimental Pathology Laboratories, Inc. (EPL).

Respiratory Physiology

A series of pulmonary function tests were performed on each animal designated for respiratory assessment. A constant volume plethysmograph (2.2 liter), maintained isothermal with an attached 16 iter reservoir bottle filled with copper mesh, was used for all measurements. This reservoir was insulated on all sides with foam rubber. In addition to the removable faceplate needed to insert the animals, the plethysmograph was equipped with several ports for the passage of EKG and transducer leads (Figure 1).

Lung volume changes were measured as proportional pressure changes using a high frequency response differential pressure transducer (Setra System 239: $\pm 0.01 \mathrm{~atm})$ referenced to a 20 liter bottle filled with copper mesh. This transducer was embedded directly into the wall of the plethysmograph to minimize frequency damping. Intra-thoracic pressure was measured with a differential pressure transducer (Sanborn 268B : $\pm 40 \mathrm{~mm} \mathrm{Hg}$ ) via a waterfilled catheter (PE-160) inserted into the esophagus of the rat to a depth of $10 \mathrm{~cm}$ from the upper incisor teeth. From the side of the $4 \mathrm{~mm}$ breathing port of the plethysmograph, a second water-filled catheter (Pentube 1 , AWG 非15) was connected to the reference side of the 268B transducer. The 

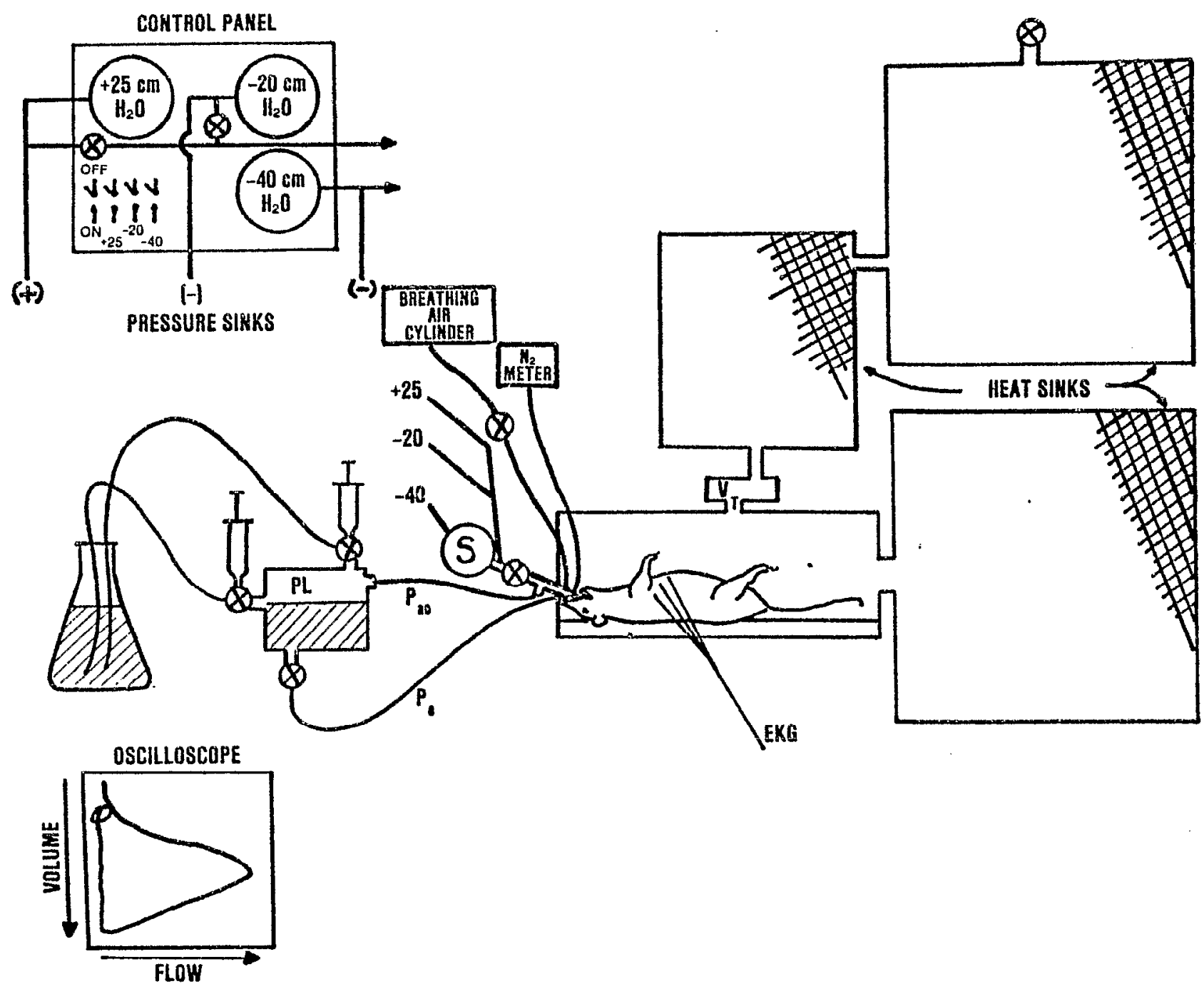

Figure 1: Schematic diagram of the plethysmograph and associated instrumentation to assess small rodent pulmonary function. 
electronic subtraction of the esophageal pressure $\left(P_{e}\right)$ from airway pressure $\left(P_{a 0}\right)$ provided the transpulmonary pressure $\left(P_{L}\right)$ or driving pressure of the lungs. Prior to animal testing, esophageal and airway catheter lengths were adjusted to ensure a constant phase relationship of transpulmonary pressure and plethysmographic pressure (calibrated as volume) to a frequency of $6 \mathrm{~Hz}$ using a piston pump ( 1 cc displacement).

When specific breathing maneuvers were not being imposed, tidal volume $\left(V_{T}\right)$, frequency of breathing $(f), P_{L}$, air flow $(V)$ as derived from $V_{T}$, pulmonary resistance $\left(R_{L}\right)$, and dynamic compliance $\left(C_{D Y N}\right)$ were recorded. Signal conditioning was achieved using HP-8805C carrier preamplifiers for $V_{T}$ and $P_{L}$. The $R_{L}$ and $C_{D Y N}$ were calculated by an analog computer (HP-8816A Respiratory Analyzer) according to the method of Mead and Whittenberger (13). Airflow, as derived by the computer module, and $C_{D Y N}$ were conditioned through a HP-8802A medium gain preamplifier. Three-lead EKGs (equivalent two lead configuration) were obtained from each animal just prior to insertion into the plethysmograph. The lead (needle) configurations formed a triangle across the animal's chest. The ground lead was attached at the base of the left front leg, the negative pole was located at the base of the right front leg and the positive pole was positioned centralaterally just below the animal's seventh rib. A second configuration with the negative lead positioned at the regional apex of the heart was also used. Heart rate, standard intervals of cardiac electrical activity, and wave forms were evaluated from these tracings. An eight-channel recorder (Gould, Brush 2800) was used for all of the above parameters.

Each animal was anesthetized with $75 \mathrm{mg} / \mathrm{kg}$ pentabarbitol (Nembutal). Controlled anesthesia was achieved by injecting $67 \%$ of the total dose followed by the remaining $33 \%$ after the loss of righting reflex. This resulted in a relatively stable level of anesthesia for a period of 
approximately two hours, sufficient time for assessment and subsequent sacrifice.

Each rat was placed in the plethysmograph in a supine position. A cannula, molded from teflon shrink tube, was transorally inserted into the trachea, effectively. by-passing the effect of the nose on all of the parameters quantified in these otherwise obligate nasal breathers. Approximately $1 \mathrm{~cm}$ from the proximal tip of the camula, a shoulder was molded to ensure an airtight seal with the glottis upon insertion. The total dead space of the cannula, including all valving to the glottis insert, was measured manometrically and adjusted to BTPS (body temperature pressure saturated). The volumes of the tracheal cannulas used ranged from 1.55 to $1.90 \mathrm{~cm}^{3}$. The "effective" dead space from the mouth opening to the distal end of the breathing port was $0.71 \mathrm{~cm}^{3}$. To offset the effect of this latter dead space on the parameters of spontaneous breathing, a bias flow of breathing air (approximately $400 \mathrm{~cm}^{3} / \mathrm{min}$ ) was introduced into the tracheal cannula through a side port to maintain fresh air in that space. The bias flow was curtailed during all other measurements.

The rat was allowed to stabilize within the system for approximately 10 to 15 minutes. This period was determined by the stability of spontaneous breathing parameters, $R_{L}$ and $C_{D Y N}$. When these tracings had satisfactorily stabilized, their average values over a 0.5 minute period were noted. SubsequentIy, a series of ventilatory maneuvers were performed on each animal to assess the following: divisions of lung volume, quasi-static compliance (QSC), multibreath $\mathrm{N}_{2}$ washout, and characterization of the maximum expiratory flow volume (MEFV) maneuver. The TLC and RV were defined as those Iung volumes corresponding to a transpulmonary pressure of $+25 \mathrm{~cm} \mathrm{H} \mathrm{H}_{2} \mathrm{O}$ and $-20 \mathrm{~cm} \mathrm{H} \mathrm{H}_{2} \mathrm{O}$, respectively. Inflation and deflation of the lungs, from endexpiration (the end of a normal tidal breath), were achieved through the use 
of a large-volume, constant-pressure reservoir controlled by a solenoid valve. Quasi-static volume $(V) /$ pressure $\left(P_{L}\right)$ relationships were determined in a similar manner, but were dictated by a defined inspiration ( $3 \mathrm{ml} / \mathrm{sec}$ ) to TLC and a slow deflation $(\sim 3 \mathrm{ml} / \mathrm{sec})$ to $R V$. The volume-pressure curves were recorded on an X-Y plotter (HP-7045A). Quasi-static compliance was measured both as the tangent slope to the steepest portion of the curve $\left(Q_{S C}\right)$ above the functional residual capacity (FRC) and as the chord slope $\left(\mathrm{QSC}_{\mathrm{cs}}\right.$ ) from 0 to $10 \mathrm{~cm} \mathrm{H_{2 }} \mathrm{OP}_{\mathrm{L}}$. The pressure span for computation of the chord slope was chosen as the typical lower and upper limits of tidal $\mathrm{P}_{\mathrm{I}}$. The FRC was measured by neon dilution as described by Takezawa et al. (14) and the Boyle's law technique (15). The "standard" gas used in the dilution measurements consisted of $0.532 \% \mathrm{Ne}, 0.497 \% \mathrm{CO}$, and $22.01 \% \mathrm{O}_{2}$ in $\mathrm{N}_{2}$. The volume injected was equal to the plethysmographically determined vital capacity (VC) adjusted to ATPD (ambient temperature pressure dry). From RV, a volume equal to $\mathrm{VC}$ (ATPD) was injected from a syringe through a three-way valve. The lungs were then ventilated ten times in approximately ten seconds with this syringe using a stroke volume of approximately $75 \%$ of the VC. The component gases of the final VC-volume withdrawn were quantitated on a gas chromatograph (Carle Basis GC 8700). The proportional dilution NE and the VC (BTPS) were used to calculate the TLC (TLC by dilution). In conjunction with the measured expiratory CO, it was possible to calculate a "rebreathing" diffusing capacity for $\mathrm{CO}\left(\mathrm{DLCO}_{r b}\right)$. Adjusting for equipment dead space and subtracting the measured inspiratory capacity provided the FRC $_{d}$ (by dilution). The $\mathrm{FRC}_{\mathrm{b}}$ (Boyle's law) was determined by occluding the airway at end expiration and comparing $\Delta \mathrm{P}_{\text {ao }}$ (airway) to $\Delta V$ with each inspiratory effort. Calculation of $V P=V^{\prime} P^{\prime}$ corrected for dead space yielded $\mathrm{FRC}_{b}$. These calculations were done on-1ine by an HP-9825 desk-top computer programmed for breath by breath calculation of the $\mathrm{FRC}_{b}$. Both 
measures of FRC (BTPS) represent the resting lung volume, up to the entry of the trachea into the naso-pharynx. The BTPS correction was based on the ambient barometric pressure and the measured body temperature $\left(\sim 34^{\circ} \mathrm{C}\right.$ ) of the rat at the time of the specific test.

Diffusing capacity for CO was measured by both a rebreathing and a single breath technique. The rebreathing technique was used to estimate a dilution TLC as described above. The equilibrated alveolar gas concentrations and the time from inspiration (gas injection) to the final expiration (expirate collection) was used in the Krogh (16) calculation $\left(\mathrm{DLCO}_{\mathrm{rb}}\right)$. The single breath estimation was determined by the method of Takezawa et al. (14). The injection of a VC volume of standard gas, corrected to ATPD, was held for 8 seconds. At that time $50 \%$ of the gas was withdrawn and discarded as mixed dead space and some alveolar gas. The second half of the expirate was assumed to represent alveolar gas. Using the duration of breath hold ( 10 seconds), the CO uptake and Ne dilution could be used to calculate the $\mathrm{DLCO}_{\mathrm{sb}}$.

Multibreath $\mathrm{N}_{2}$ washout was measured by sampling end-expiratory (alveolar) gas directly in the tracheal tube while the animal was breathing $100 \% \mathrm{O}_{2}$ which flowed by the tracheal tube opening at approximately $400 \mathrm{~cm}^{3} /$ min. A total of 50 breaths were sampled for each animal. The natural log of the end-expiratory $\mathrm{N}_{2}$ concentration was plotted against breath number or dilution value $\frac{V_{\mathrm{T}} \cdot \text { breath } \#}{\mathrm{FRC}_{\mathrm{d}}}$ by the HP-9825 computer from data collected on-1ine during the maneuver. Moment analyses was then used to assess the degree of ventilatory inhomogeneity.

The MEFV curve was an imposed expiratory maneuver. After slow inflation to TLC, a volume held for approximately three seconds, a pressure sink of $-40 \mathrm{~cm} \mathrm{H} \mathrm{H}_{2} \mathrm{O}$ was exposed to the tracheal port of the plethysmograph by 
activating a wide bore solenoid valve (Skinner Valve - V53DB2VAC2, $1 / 4^{\prime \prime}-3 / 32^{\prime \prime}$ orifice). The tubing from the sink to the valve, as well as between the valve and tracheal port, was as large and rigid as practically possible. With closed vials used to represent body mass and $10 \mathrm{cc}$ of air injected into the closed plethysmograph, the time to peak flow for the system with the tracheal tube in place was $50 \mathrm{msec}$. For each animal, peak expiratory flow (PEF), expiratory flow at 50, 25, and $10 \% \mathrm{VC}\left(\mathrm{EFR}_{50}, \mathrm{EFR}_{25}\right.$, and $\mathrm{EFR}_{10}$, respectively), and the percent expired $\mathrm{VC}$ at $\mathrm{PEF}$ were recorded. The $\triangle \mathrm{EFR}_{25}$ was measured as the difference in flow at $25 \% \mathrm{VC}$ above or below that volume estimated by a chord slope drawn from $\mathrm{EFR}_{50}$ to $\mathrm{EFR}_{0}$. A positive $\triangle E F R_{25}$ is a measure of the degree of convexity (away from the volume axis) of the effort independent portion of the MEFV curve and conversely, a negative $\triangle E F R_{25}$ is a measure of curve concavity (toward the volume axis).

Using the MEFV and quasi-static compliance data, maximum-flow static recoil (MFSR) curves were derived for the determination of "upstream" airway resistance during the MEFV maneuver. The upstream airway resistance $\left(R_{u s}\right)$ of each animal was calculated as the static pressure ( $P_{s t}$ divided by $\dot{V}$ ) at $45 \%$ of its lung volume. The existence of airway obstruction and/or loss of tissue elasticity as the potential cause of the decreased flow thereby could be deduced.

Pathological Examination

Animals from each chamber designated for pathological examination were anesthetized with Nembutal and exsanguinated via the descending aorta. The thorax was opened and the heart and Iungs were removed intact. The trachea was detached at the larynx and the thymus, heart, lymph nodes, epicardial fat, and esophagus were carefully removed from the respiratory tissue. The lungs were patted dry and weighed with the trachea still attached. The 
lungs were then infused with $2.5 \%$ glutaraldehyde in Sorenson's buffer at $25 \mathrm{~cm}$ water pressure for 30 minutes. After the infusion period, the left lung of four randomly selected animals from each exposure group was submerged in the glutaraldehyde fixative for 3.5 hours, after which tissue slices were removed for possible future electron microscopy studies. The remaining lungs were placed in $10 \%$ buffered formalin immediately after the 30 minute infusion. The remainder of the left lobe from which slices had been removed was also placed in formalin. The following tissues were collected and stored in formalin: eyes, pituitary, thyroid, salivary glands, cervical lymph node, larynx, trachea, thymus, peribronchial lymph node, heart, esophagus, stomach, small intestine, large intestine, liver, pancreas, adrenal, mesenteric lymph node, urinary bladder, gonads, prostate, sternum, rib junction, skeletal muscle, peripheral nerve, skin, spleen, and nasal cavity. All pathological examinations were done under contract by Experimental Pathology Laboratories, Inc. (Herndon, Virginia). Microscopic examination was conducted on hematoxylin and eosin stained sections of lung, peribronchial lymph node, nasal turbinate, brain, kidney, liver, spleen, testes, and heart from eight control, low dose, and intermediate dose animals and three high dose rats.

The left lung of all the animals which completed the pulmonary function regime was submitted for histopathologic examination. This provided pathology, respiratory physiology, and biochemical data on individual animals, and also served to determine whether the respiratory physiology testing regime itself induced pulmonary damage. Numerical values were generated from the histopathology sections by adding up the values which indicated the severity of the pulmonary lesions observed. The scored lesions included: alveolitis, type II cell hyperplasia, alveolar macrophages, bronchiolar epithelial necrosis and sloughing, hemorrhage, 
bronchiolar edema and macrophages and chronic pleuritis. These sums were then ranked $1-n$, where $n$ is the maximum number of samples in the group being ranked.

Determination of Lung Composition

The right lung of each rat completing pulmonary function tests was weighed, homogenized in water using a Polytron Homogenizer (Brinkman Instruments), and the total volume brought to $10 \mathrm{ml}$ with water. Suitable aliquots were then taken for determination of dry weight, by freeze drying in tared tubes, and for chemical analyses.

Collagen content was determined and reported as total hydroxyproline in the sample. Hydroxyproline was determined by the method of Bergman and Loxley (17) after hydrolysis of the aliquot in $6 \mathrm{~N} \mathrm{HCl}$ at $105^{\circ}-110^{\circ} \mathrm{C}$ in an evacuated tube for $22 \mathrm{hr}$. Elastin was considered to be the insoluble protein remaining after treatment of an aliquot with $0.1 \mathrm{~N} \mathrm{NaOH}$ at $98^{\circ} \mathrm{C}$ for $0.5 \mathrm{hr}$. It was determined by the method of Naum and Mogan (18) and compared with a sample of bovine ligamentum nuchae elastin (Sigma) as standard. Total protein was determined by the Hartree (19) modification of the Folin-Lowry method. DNA was determined according to Burton (20) after heating a sample in $5 \%$ perchloric acid at $90^{\circ} \mathrm{C}$ for 12 min (conditions found to give the maximum color).

Cytological Methods

On the sixth day following the final exposure rats deslgnated for cytological studies were briefly anesthesized with enflurane, and placed in modified Bollman restrainers (21). Tail veins were cannulated with hubless 23 gauge needles inserted into Clay Adams P.E. tubing attached to $1 \mathrm{ml}$ syringes loaded with isotonic phosphate buffered saline (PBS, $\mathrm{pH}$ 7.3). After cannulation, the P.E. 50 tubing was attached to similar tubing 
originating at a Watson-Marlow 10-Channel peristaltic pump with auto analyzer tubing (Gamma Enterprises). The pump delivered bromodeoxyuridine (BrdUrd), dissolved in $\mathrm{PBS}$, at a rate of $50 \mathrm{mg} / \mathrm{kg}$ body weight/hour (flow rate $240 \mathrm{ml} / 24$ hours) for 24 hours. During this time, the animals were provided food and water ad 1ibitum. After 23 hours, the animals were intravenously injected with colcemid (20 mg/250 gms body weight). One hour later the tubing was removed and one hour after that (total elapsed time 25 hours) the animals were sacrificed by barbituate overdose administered intraperitoneally.

Immediately after cessation of breathing, the chest cavity was opened and a sample $(\sim 3 \mathrm{ml})$ of blood was obtained by cardiac puncture using a heparinized $3 \mathrm{cc}$ syringe and 22 gauge needle. This blood was stored in sterile tubes containing lithium heparin until cultured. Whole blood $(.25 \mathrm{ml})$ was innoculated into $5 \mathrm{ml}$ McCoy's SA medium containing $10 \%$ fetal calf serum, (Sigma), and $15 \mathrm{mg} / \mathrm{ml}$ phytohemagglutinin-P (PHA-P) (Burroughs Wellcome). Complete cultures were incubated at $38^{\circ} \mathrm{C}$ for 48 and 72 hours in darkness. Colcemid (.I mg/ml) (Gibco) was added to each culture four hours before termination. At termination the cultures were centrifuged and the pellet was resuspended in hypotonic KCI $(0.075 \mathrm{~m})$ for 15 minutes at room temperature. The cells were then fixed twice in methanol:glacial acetic acid $(3: 1)$, and stored at $0^{\circ} \mathrm{C}$ until slides were processed (22). Both femurs were removed and the bone marrow rinsed out using PBS. The resulting material was incubated in hypotonic $\mathrm{KCl}(0.075 \mathrm{~m})$ for 20 min at $37^{\circ} \mathrm{C}$, then fixed twice in methanol:glacial acetic acid $(3: 1)$, and finally stored at $0^{\circ} \mathrm{C}$ until processed for slides (21).

Both epididymes were removed and minced in PBS, and the large particles allowed to settle. The resulting supernatant containing sperm was spread onto clean microscope slides and fixed for $10 \mathrm{~min}$ in methanol: 
glacial acetic acid $(3: 1)(23,24)$.

To obtain lung alveolar macrophages, the trachea of each rat was exposed and cannulated with tubing attached to a $5 \mathrm{cc}$ syringe. Five $\mathrm{ml}$ of PBS (room temperature) was forced into the lungs and allowed to remain for $25 \mathrm{~min}$; it was then removed and placed into a $50 \mathrm{ml}$ centrifuge tube, and another $5 \mathrm{ml}$ volume was forced into the same lungs. When $50 \mathrm{ml}$ PBS had been retrieved from the lungs of each animal, it was centrifuged and the pellet was resuspended in hypotonic $\mathrm{KCl}(0.075 \mathrm{~m})$ for $25 \mathrm{~min}$ at $37^{\circ} \mathrm{C}$. The cells were then fixed twice in methanol:glacial acetic acid $(3: 1)$ and stored at $0^{\circ} \mathrm{C}$ until processed for slides (25).

Al1 processed material (with the exception of sperm) was flame-dried on microscope slides, stained with Hoechst $33258\left(0.5 \mathrm{mg} / \mathrm{ml}\right.$ distilled $\left.\mathrm{H}_{2} \mathrm{O}\right)$ for $20 \mathrm{~min}$, mounted with phosphate:citric acid buffer ( $\mathrm{pH} 7.0$ ), exposed to blacklight fluorescent tubes $(02.5 \mathrm{~cm}$ distance) for $25 \mathrm{~min}$, and then stained with Giemsa ( $4 \%$ Harledo Giemsa and $4 \%$ methanol in distilled $\mathrm{H}_{2} \mathrm{O}$ ) for $\sim 5.5$ min (26). Sperm slides were stained with $0.02 \%$ eosin $Y$ for $30 \mathrm{~min}$.

One hundred randomly chosen metaphase cells in each sample were scored for the number of times they had replicated (one, two, or more replications), as distinguished by their BrdUrd staining patterns (27). Where possible, 25 second generation metaphase cells were scored for the number of sister chromatid exchanges (SCEs) (21) and 50 first generation metaphase cells were scored for chromosomal aberrations (28). Finally, 500 sperm were examined from each animal to determine the frequency of morphologically abnormal specimens $(22,23)$.

Reproductive Potential Methods

Six days after the final exposure, eight male rats from the control, $0.4 \mathrm{ppm}$, and $1.4 \mathrm{ppm}$ acrolein chambers and five from the $4.0 \mathrm{ppm}$ chamber 
of the sum of squares between groups to the sum of squares within groups. This is also called the first canonical variate. The second discriminant function, or the second canonical variate, was the function of the highest ratio orthogonal to the first. Similarly, the third function gave the highest ratio conditioned to the orthogonality to the first and second functions. The maximum number of discriminant functions derived was one less than the number of exposure groups involved or equal to the number of discriminant variables in the analysis, whichever was smaller. The corresponding eigenvalue and associated canonical correlations for each function denoted the relative ability of the function to separate groups. When the sign was ignored, the coefficient of the function represented the contribution of its associated variable to the function. If most of the variation among the groups was explained by the first and second canonical variates, the tendency of the groups to form clusters was examined by plotting the first versus the second canonical variables.

To assess the adequacy of the discriminating variables, the original exposed animals were categorized by a series of classification functions, one for each group. These classification functions were derived from the pooled within-group covariance matrix and the centroids for the discriminant variables. These classification functions produced one score for each animal for each respective group and the rat was assigned to the group with the nearest centroid (smallest Mahalanobis D-square). The percent current classification for each group was given by the BMDP $7 M$ procedure (3). 


\section{RESULTS}

General Toxicology Parameters

Exposure Conditions. The temperature and relative humidity in the chambers was continuously monitored. During the hours of acrolein exposure the temperature was maintained at about $21^{\circ} \mathrm{C}$; however, extremes of $18^{\circ} \mathrm{C}$ and $24^{\circ} \mathrm{C}$ were recorded. The relative humidity ranged from 50 to 70 percent.

The acrolein concentration in each chamber was automatically measured with a MIRAN 80-A infrared analyzer. The MIRAN absorption readings were converted to ppm values by means of linear regression calibration plots (Figure 2) and these were used to calculate the daily time weighted averages (Table 1). Copies of chamber data sheets from four randomly selected days have been provided in Appendix $D$.

Animal Mortality. Mortality among male rats exposed to $4.0 \mathrm{ppm}$ acrolein reached $56 \%(32 / 57)$ while none of the female rats in the high dose chamber died. The greatest mortality occurred from the 8 th through the 10th day of exposure (Figure 3). Animals were introduced into the chambers on four of the five exposure days of the week; therefore, the high mortality observed on days 8 through 10 was not a reflection of 3-5 consecutive days of acrolein insult during the second week of exposure. Deaths appeared to occur without pattern throughout the week with $3,4,6,4,8,5$, and 2 deaths on Sunday through Saturday, respectively.

Animal Weights. Both male and female rats in the $4.0 \mathrm{ppm}$ acrolein chamber lost weight during the first 10 exposure days (Figures 4 and 5 ). Although all of the animals in each exposure group were weighed weekly, only data from the largest sub-groups entering the chambers on a single day were plotted and analyzed (survivors only in the male 4.0 ppm subgroup). 
were each housed with two unexposed females for seven days. Eight females from each exposure level were mated with unexposed males $(1: 1)$ that had previously been mated with unexposed females to assure that they were fertile. All females from these matings were sacrificed 19 days after the first mating as determined by the presence of sperm in the vaginal smears. Upon sacrifice, the numbers of viable embryos, late deaths, early deaths (reabsorptions), and corpea lutea were determined. Preimplantation losses were also evaluated.

\section{Statistical Methods}

Student's t-test was employed when the variable mean of a control group was compared to that of an exposure group. When the probability that two means were from the same population was less than 0.05 , they were considered significantly different.

When the mean values of a single parameter were compared among the exposure groups, one way analysis of variance (ANOVA) was employed. If a significant difference among the groups was indicated, the Bonferroni multiple comparison technique was used to compare individual groups. In these cases the probability limit of 0.05 was divided by the number of comparisons made to protect the confidence 1 imit.

Differences among the groups based on histopathologic data (nonparametrically ranked) were examlned by the Kruskall-Wallis test. A non-parametric multiple comparison technique proposed by Dun (30) was then used to compare the possible paired combinations of exposure groups.

Sister chromatid exchange data was subjected to square root transformation. This served to normalize the distribution of the data and resulted in greater homogeneity of variance. The Student's $t$ test was then used to analyze the data. Bone marrow and peripheral blood lymphocyte population kinetics were analyzed using the Student's t-test after transformation of 
the data from each animal to a mean cell cycle number. The mean cell cycle number $=\frac{I(I)+2(I I)+3(I I I)}{100} ;$ where I, II, and III are the proportions of total cells scored (100) in the first, second, and third generations, respectively. The data on the percentage of abnormal sperm from each exposure group was analyzed by the Kruskal1-Wallis non-parametric test and by one-way analysis of variance after arcsine transformation of the data.

The combined respiratory physiology, lung composition, and histopathologic endpoint assessment of individual animals resulted in 26 pulmonary variables from each animal which could be evaluated by correlation analysis. Linear associations were investigated between the three general classes of data (respiratory physiology, Iung composition, and histopathology) within individual exposure groups.

The Pearson product-moment correlation was used when the parametric respiratory physiology and lung composition data were analyzed. Investigation of associations between the ranked pathology scores and the parametric data was conducted with the Spearman rank correlation test. However, the parametric respiratory physiology and lung composition data had to be transformed to a ranked system for this statistical analysis. The coefficients which resulted from these correlation procedures were transformed to t-statistics (29) and associations with probabilities of less than 0.05 were considered significant.

The data from the respiratory physiology studies and the lung composition analysis were also subjected to stepwise discriminant analysis. This stepwise procedure provided a reduced set of parameters, which most effectively discriminated the groups involved in a particular analysis. The first discriminant function was so derived as to maximize the ratio 
This precluded complication of the data by excluding weights of animals which differed in age. One way analysis of variance indicated that the low and intermediate dose male animals were significantly $(p<0.0083$ by Bonferroni multiple comparison) heavier than the control males the first day of exposure. This difference was not noted again throughout the exposure regime. Male rats exposed to $4.0 \mathrm{ppm}$ acrolein gained weight at a significantly reduced rate. Among the female exposure groups the weights of the 0.4 and $4.0 \mathrm{ppm}$ animals differed significantly at the first weighing. At all subsequent weighings the weight of the high dose group was significantly less than that of the other groups among which there were no significant differences.

The weight changes of the individual groups during a six day period following removal of the animals from the chambers have been indicated in Figures 4 and 5. Groups of male and female rats removed from the $4.0 \mathrm{ppm}$ chamber gained 35.1 (s.e. \pm 4.34 ) and 24.0 (s.e. \pm 1.58 ) gms, respectively, over the six day post-exposure period. Among the control, low, and intermediate exposure groups the six day post-exposure weight gain was less marked. The average weight gain among males and females in these groups was 12.3 and $7.6 \mathrm{gms}$, respectively. The weight of the rats from the high dose chamber differed significantly from those of the other exposure groups at the time of endpoint assessment. Also, the male rats from the $1.4 \mathrm{ppm}$ chamber were significantly heavier than those from the control chamber six days post-exposure.

Organ Weight and Organ-to-Body Weight Ratios. The organ weight data provided in Tables 2 and 3 were derived from the animals designated for pathology from each exposure group. Additional lung data were available from those animals used in the respiratory physiology study, and these are 
provided in Table 4.

Statistical analysis of the data in Table 2 indicated that the absolute organ weights of the low- and intermediate-dose rats did not differ significantly from those of the control group. Because the animals from the $4.0 \mathrm{ppm}$ chamber were significantly 1ighter than those of the other groups (Table 2), most of the organ weights were also significantly less. However, the brain weights of these animals were not different from those of other groups. The lungs (with trachea attached) of the markedly smaller 4.0 ppm animals were significantly heavier than those from animals exposed to 0.4 and $1.4 \mathrm{ppm}$ acrolein. When lung weights were examined as a function of body weight (Table 3), the ratio for the high dose group was markedly greater than that for any other group. Similar lung weights and lung-tobody weight ratios were also observed from animals in the respiratory physiology subgroups. The organ-to-body weight ratios of all organs, with the exception of the liver, in the high dose group were significantly greater than for animals from the other chambers. 


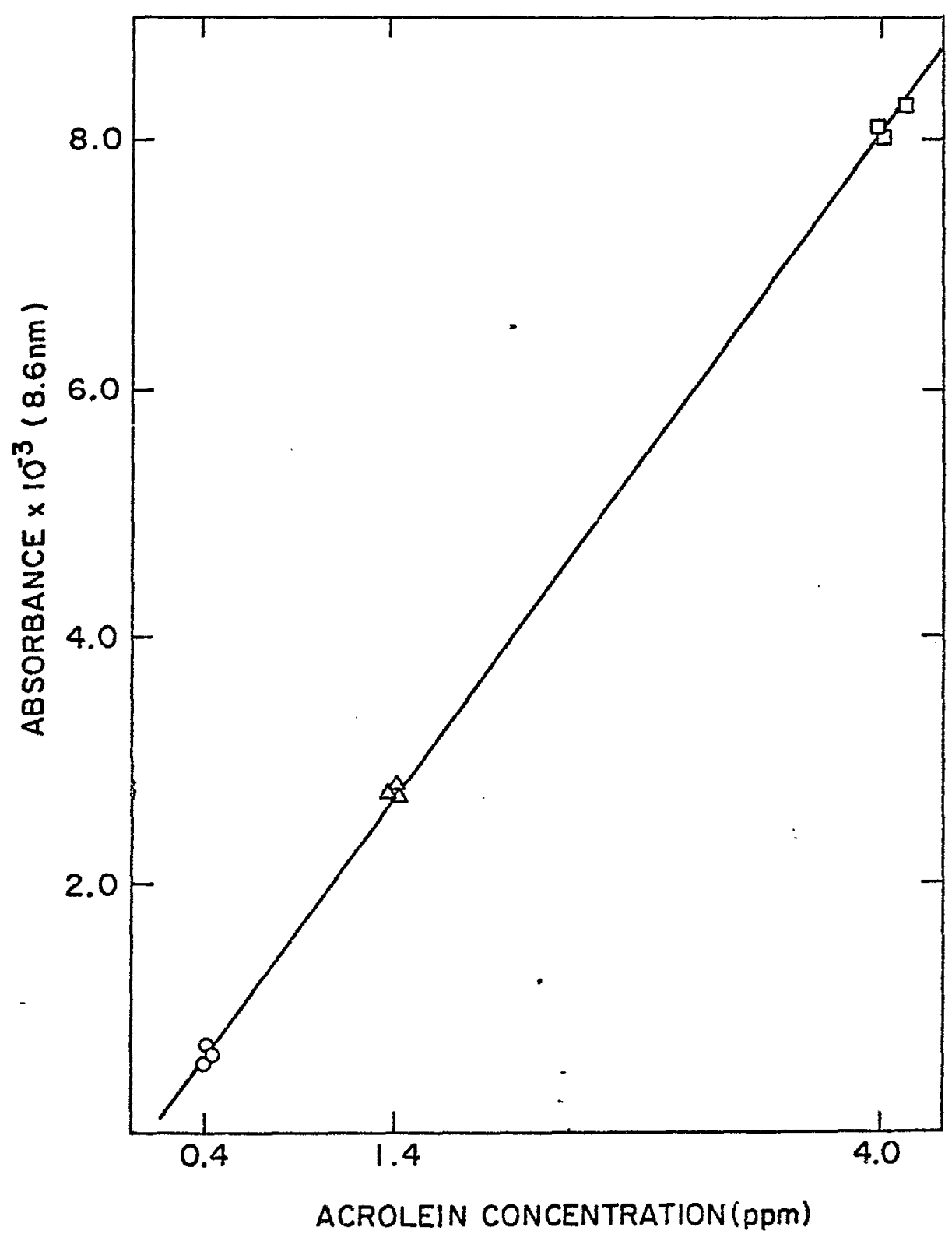

Figure 2: Linear regression plot of MIRAN 80-A absorbance values and concurrent acrolein concentrations determined by chemical analysis for each chamber (0.4 ppm (o), $1.4 \mathrm{ppm}(\Delta)$, and $4.0 \mathrm{ppm}(\square))$ on three separate exposune days. 
Table 1. Daily Mean Chamber Concentrations of Acrolein

\begin{tabular}{|c|c|c|c|}
\hline Specified Concentration (ppm) & 0.4 & 1.4 & 4.0 \\
\hline Exposure Day & \multicolumn{3}{|c|}{ Daily Meän Concentration (ppm) } \\
\hline 1 & 0.402 & 1.430 & 4.058 \\
\hline 2 & 0.410 & 1.434 & 4.116 \\
\hline 3 & 0.416 & 1.440 & 4.180 \\
\hline 4 & 0.438 & 1.499 & 4.506 \\
\hline 5 & 0.400 & 1.426 & 4.187 \\
\hline 6 & 0.363 & 1.367 & 3.718 \\
\hline 7 & 0.382 & 1.327 & 3.814 \\
\hline 8 & 0.392 & 1.375 & 3.783 \\
\hline 9 & 0.415 & 1.480 & 4.068 \\
\hline 10 & 0.325 & 1.307 & 3.659 \\
\hline 11 & 0.375 & 1.380 & 3.611 \\
\hline 12 & 0.459 & 1.557 & 4.200 \\
\hline 13 & 0.485 & 1.502 & 4.033 \\
\hline 14 & 0.462 & 1.476 & 3.915 \\
\hline 15 & 0.443 & 1.495 & 3.855 \\
\hline 16 & 0.428 & 1.419 & 3.922 \\
\hline 17 & 0.397 & 1.417 & 3.861 \\
\hline 18 & 0.304 & 1.442 & 3.926 \\
\hline 19 & 0.360 & 1.370 & 4.084 \\
\hline 20 & 0.443 & 1.442 & 4.239 \\
\hline 21 & 0.421 & 1.488 & 4.238 \\
\hline 22 & 0.412 & 1.491 & 4.232 \\
\hline 23 & 0.375 & 1.463 & 4.076 \\
\hline 24 & 0.393 & 1.376 & 3.749 \\
\hline 25 & 0.398 & 1.509 & 4.028 \\
\hline 26 & 0.366 & 1.518 & 3.955 \\
\hline 27 & 0.482 & 1.438 & 3.935 \\
\hline 28 & 0.315 & 1.389 & 3.899 \\
\hline 29 & 0.366 & 1.374 & 3.907 \\
\hline 30 & 0.352 & 1.275 & 3.751 \\
\hline 31 & 0.354 & 1.257 & 3.367 \\
\hline 32 & 0.456 & 1.402 & 3.889 \\
\hline 33 & 0.419 & 1.498 & 4.010 \\
\hline 34 & 0.388 & 1.343 & 3.980 \\
\hline
\end{tabular}




\begin{tabular}{|c|c|c|c|}
\hline & 0.4 & 1.4 & 4.0 \\
\hline 35 & 0.366 & 1.345 & 3.894 \\
\hline 36 & 0.341 & 1.650 & 3.957 \\
\hline 37 & 0.388 & 1.348 & 4.068 \\
\hline 38 & 0.291 & 1.327 & 3.982 \\
\hline 39 & 0.353 & 1.400 & 4.012 \\
\hline 40 & 0.412 & 1.413 & 3.887 \\
\hline 41 & 0.412 & 1.430 & 3.918 \\
\hline 42 & 0.459 & 1.453 & 4.035 \\
\hline 43 & 0.359 & 1.399 & 3.900 \\
\hline 44 & 0.378 & 1.395 & 3.874 \\
\hline 45 & 0.462 & 1.376 & 3.954 \\
\hline 46 & 0.396 & 1.460 & 3.981 \\
\hline 47 & 0.453 & 1.504 & 4.050 \\
\hline 48 & 0.332 & 1.430 & 4.017 \\
\hline 49 & 0.357 & 1.335 & 3.928 \\
\hline 50 & 0.399 & 1.409 & 3.898 \\
\hline 51 & 0.375 & 1.440 & 3.989 \\
\hline 52 & 0.410 & 1.376 & 4.042 \\
\hline 53 & 0.375 & 1.384 & 4.012 \\
\hline 54 & 0.374 & 1.321 & 3.903 \\
\hline 55 & 0.389 & 1.397 & 3.961 \\
\hline 56 & 0.419 & 1.583 & 4.338 \\
\hline 57 & 0.425 & 1.428 & 3.836 \\
\hline 58 & 0.373 & 1.442 & 3.895 \\
\hline 59 & 0.397 & 1.392 & 4.029 \\
\hline 60 & 0.382 & 1.356 & 3.952 \\
\hline 61 & 0.366 & 1.340 & 3.895 \\
\hline 62 & 0.428 & 1.442 & 4.009 \\
\hline 63 & 0.371 & 1.395 & 3.984 \\
\hline 64 & 0.397 & 1.394 & 3.980 \\
\hline 65 & 0.396 & 1.374 & 3.977 \\
\hline 66 & 0.323 & 1.220 & 3.740 \\
\hline 67 & 0.390 & 1.442 & 3.959 \\
\hline 68 & 0.374 & 1.432 & 4.159 \\
\hline 69 & 0.381 & 1.399 & 3.900 \\
\hline 70 & 0.387 & 1.281 & 3.781 \\
\hline
\end{tabular}


Table 1 - continued

$\begin{array}{lccr} & 0.4 & 1.4 & 4.0 \\ 71 & 0.333 & 1.421 & 4.020 \\ 72 & 0.456 & 1.477 & 4.042 \\ 73 & 0.387 & 1.386 & 3.960 \\ 74 & 0.398 & 1.385 & 4.015 \\ 75 & 0.390 & 1.405 & 3.933 \\ 76 & 0.410 & 1.434 & 3.926 \\ 77 & 0.429 & 1.430 & 3.963 \\ 78 & 0.397 & 1.491 & 3.990 \\ 79 & 0.337 & 1.327 & 3.897 \\ 80 & 0.406 & 1.434 & 4.074 \\ 81 & 0.462 & 1.459 & 4.055 \\ 82 & 0.384 & 1.354 & 3.954 \\ 83 & 0.440 & 1.409 & 3.995 \\ 84 & 0.448 & 1.380 & 3.961 \\ 85 & 0.382 & 1.410 & 3.873 \\ 86 & 0.415 & 1.454 & * \\ 87 & 0.403 & 1.381 & -1.379 \\ 88 & 0.376 & 1.95 & -1\end{array}$

*High dose (4.0 ppm) exposures terminated 


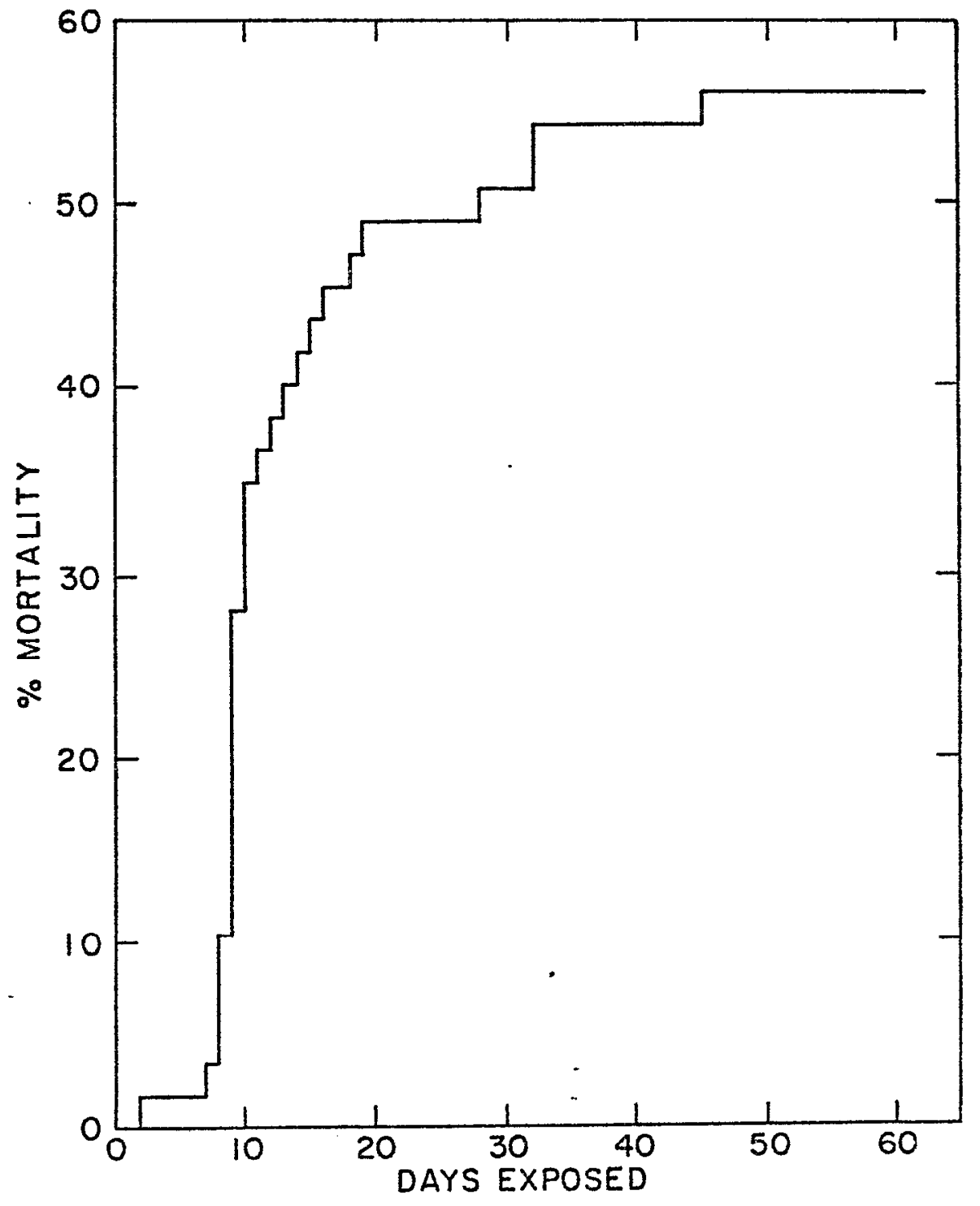

Figure 3: Mortality among male Fischer 344 rats exposed to $4.0 \mathrm{ppm}$ acrolein for 62 days ( 6 hours/day, 5 days/week). 


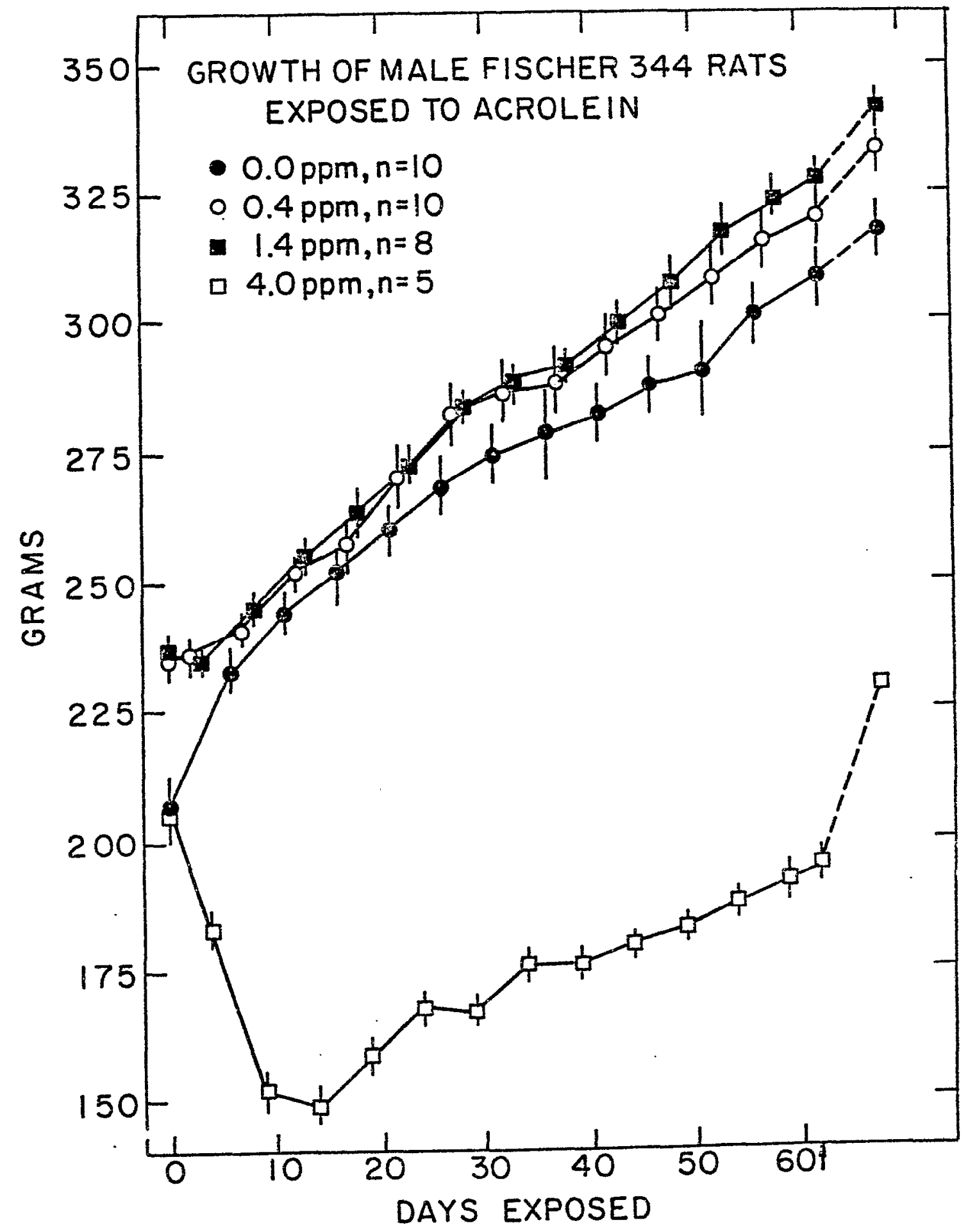

Figure 4: Weights of control and acrolein-exposed male Fischer 344 rats ( $\uparrow$; final exposure). 


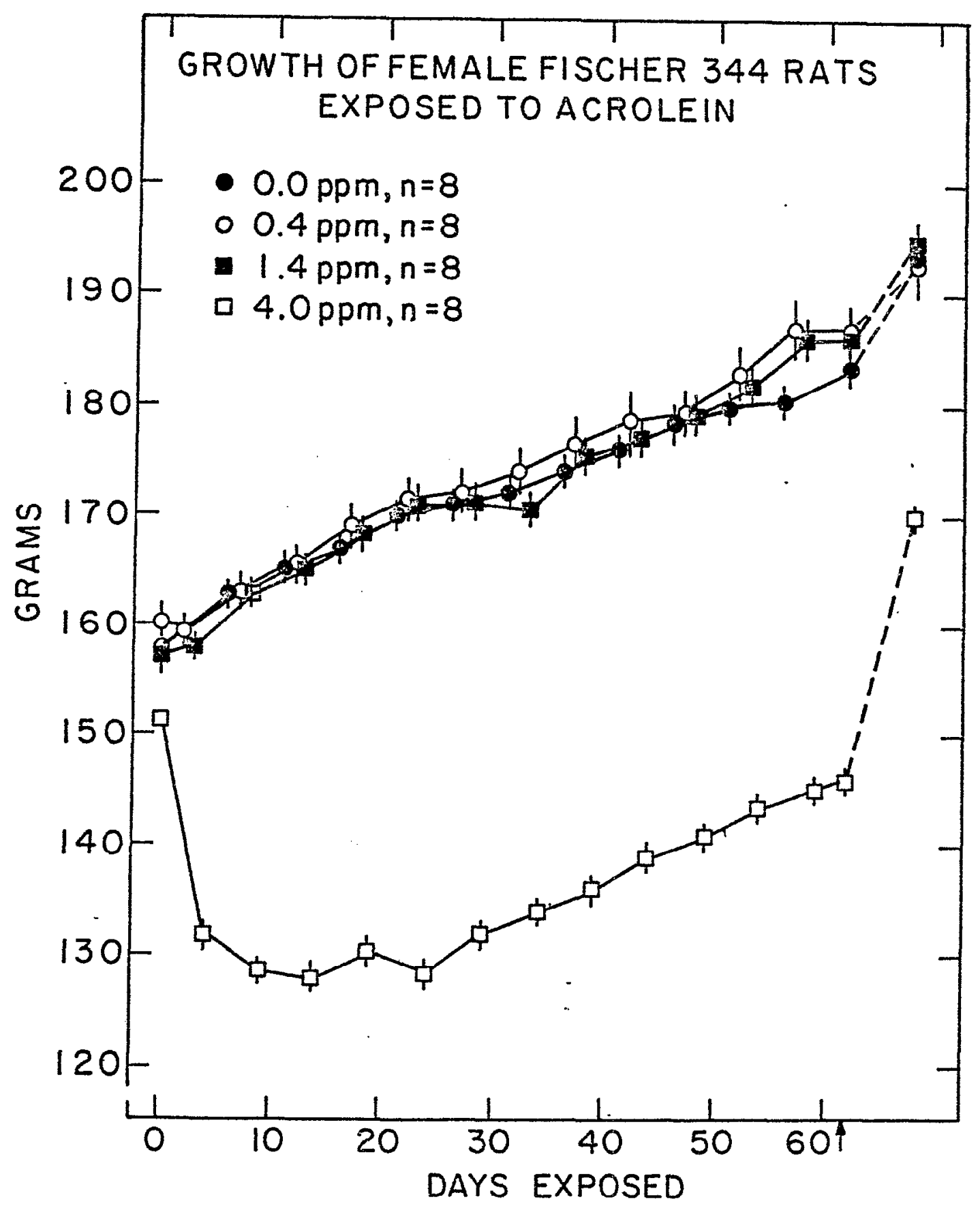

Figure 5: Weights of control and acrolein-exposed female Fischer 344 rats ( $\uparrow$; final exposure). 
Table 2. Results and Statistical Analysis of Absolute Organ Weight and Body Weights of Fischer 344 Rats Exposed to Acrolein ${ }^{a}$

ACROLEIN CONCENTRATION (PPM)

\begin{tabular}{|c|c|c|c|}
\hline 0.0 & 0.4 & 1.4 & 4.0 \\
\hline $\mathrm{n}=8$ & $\mathrm{n}=8$ & $\mathrm{n}=8$ & $\mathrm{n}=5$ \\
\hline
\end{tabular}

$\begin{array}{lcccc}\begin{array}{l}\text { LUNGS \& } \\ \text { TRACHEA }\end{array} & 1.52(0.08)^{b} & 1.44(0.04) & 1.34(0.06) & 1.70(0.08)^{c} \\ \text { HEART } & 0.99(0.04) & 1.04(0.04) & 0.95(0.02) & 0.82(0.04)^{d} \\ \text { SPLEEN } & 0.72(0.03) & 0.68(0.04) & 0.71(0.04) & 0.48(0.02)^{\mathrm{e}} \\ \text { KIDNEYS } & 2.42(0.08) & 2.50(0.09) & 2.30(0.06) & 2.00(0.08)^{\mathrm{d}} \\ \text { LIVER } & 11.44(0.46) & 12.14(0.59) & 11.12(0.21) & 7.98(0.30)^{\mathrm{e}} \\ \text { BRAIN } & 1.94(0.03) & 1.95(0.05) & 1.98(0.15) & 1.76(0.02)^{\mathrm{f}} \\ \text { TESTIS } & 3.10(0.04) & 2.94(0.12) & 3.06(0.04) & 2.62(0.12)^{f} \\ \text { BODY WEIGHT } & 340.4(8.2) & 343.7(6.8) & 327.4(5.1) & 229.2(9.3)^{\mathrm{e}}\end{array}$

${ }^{a}$ Six hours/day, five days/week, 62 days.

${ }^{b}$ Grams, mean (ts.e.).

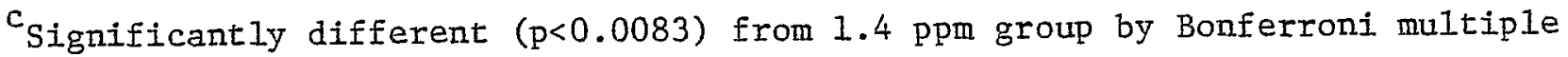
comparison technique.

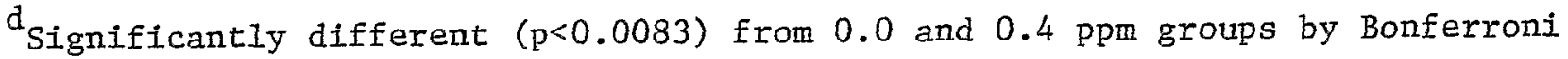
multiple comparison technique.

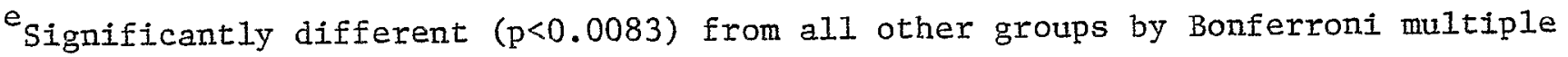
comparison technique.

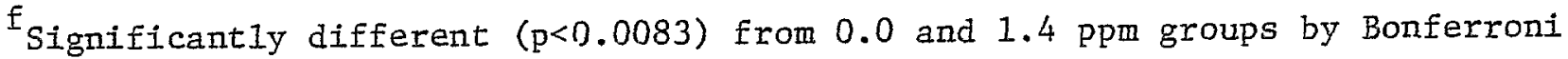
multiple comparison technique. 
Table 3. Results and Statistical Analysis of Organ-to-Body Weight

Ratios of Fischer 344 Rats Exposed to Acrolein

ACROLEIN CONCENTRATION (pPM)

$\begin{array}{llll}0.0 & 0.4 & \frac{1.4}{n=8} & 4.0 \\ n=8 & n=5 & n=5\end{array}$

\begin{tabular}{|c|c|c|c|c|}
\hline $\begin{array}{l}\text { LUNGS \& } \\
\text { TRACHEA }\end{array}$ & $4.47(0.18)^{b}$ & $4.20(0.16)$ & $4.09(0.18)$ & $7.41(0.27)^{c}$ \\
\hline HEART & $2.90(0.12)$ & $3.02(0.08)$ & $2.90(0.04)$ & $3.59(0.20)^{c}$ \\
\hline SPLEEN & $2.13(0.06)$ & $1.96(0.12)$ & $2.17(0.09)$ & $2.10(0.09)$ \\
\hline KIDNEYS & $7.13(0.18)$ & $7.27(0.20)$ & $7.02(0.12)$ & $8.72(0.14)^{c}$ \\
\hline LIVER & $33.55(0.90)$ & $35.29(1.50)$ & $34.01(0.65)$ & $34.78(0.74)$ \\
\hline BRAIN & $5.71(0.12)$ & $5.67(0.11)$ & $6.08(0.56)$ & $7.70(0.28)^{c}$ \\
\hline TESTIS & $9.13(0.16)$ & $8.56(0.36)$ & $9.36(0.10)$ & $11.40(0.23)^{c}$ \\
\hline
\end{tabular}


Table 4. Results and Statistical Analysis of Lung Weight and Lung-to-Body Weight Ratios of Fischer 344 Rats, Designated for Respiratory Physiology Studies After Exposure to Acrolein

ACROLEIN CONCENTRATION

\begin{tabular}{|c|c|c|c|c|}
\hline & & JLE & - & \\
\hline & 0.0 & 0.4 & 1.4 & 4.0 \\
\hline & $n=24$ & $\mathrm{n}=23$ & $\mathrm{n}=22$ & $\mathrm{n}=9$ \\
\hline Lung Weight (gms) & $1.29(0.02)^{b}$ & $1.28(0.03)$ & $1.35(0.04)$ & $1.71(0.06)^{c}$ \\
\hline Body Weight (gms) & $326.1(2.7)$ & $336.9(4.5)$ & $330.5(3.6)$ & $241.0(3.1)^{c}$ \\
\hline$\frac{\text { Lungs (gms) }}{\text { Body (kg) }}$ & $3.96(0.06)$ & $3.81(0.07)$ & $4.09(0.14)$ & $7.10(0.28)^{\mathrm{c}}$ \\
\hline
\end{tabular}

${ }^{a}$ Six hours/day, five days/week, 62 days.

bean (ts.e.).

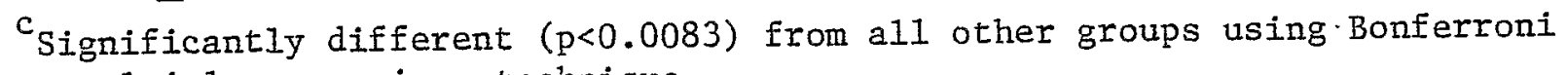
multiple comparison technique. 
Respiratory Physiology

The Student's t-test was used to compare the pulmonary function data of each exposure group to that of the controls and the term "significant" for these analyses denotes a probability (p) of less than 0.05 . During . the function tests an occasional data point could not be measured, resulting in its omission from statistical analysis. The actual number of data points considered in each analysis has been provided in the respective tables. The pulmonary function data from all animals tested have been provided in Appendix E.

Parameters of Spontaneous Breathing. Several measurements of normal tidal breathing were taken on each animal prior to the forced ventilatory maneuvers (Table 5). The $4.0 \mathrm{ppm}$ animals exhibited significant changes in $\mathrm{V}_{\mathrm{T}}(+26 \%)$, $\mathrm{f}(-41 \%)$, and $\mathrm{R}_{\mathrm{L}}(+83 \%)$ when compared to control animals. No statistically significant changes in $\Delta \mathrm{P}_{\mathrm{L}}$ and $\mathrm{C}_{\mathrm{DYN}}$ were observed. The 0.4 and $1.4 \mathrm{ppm}$ exposure concentrations did not significantly affect any of these physiological parameters. Normalization of $C_{D Y N}$ and $R_{I}$, to the FRC* of each animal, altered the respective dose-related patterns of response (Figure 6). While unadjusted $C_{\text {DYN }}$ was unaffected at each exposure level, $\mathrm{C}_{\text {DYN }} / \mathrm{FRC}$ decreased 7,25 , and $41 \%$ relative to the controls with each concentration increment. However, only the $4.0 \mathrm{ppm}$ animals were significantly different from the control group. Normalization of $R_{I}$ to FRC (Figure 6) eliminated the apparent $\mathrm{R}_{\mathrm{L}}$ increase observed at $4.0 \mathrm{ppm}$. Dose related changes in $R_{\mathrm{L}} / \mathrm{FRC}$ were not evident.

Heart Rate. No significant alterations in heart rate were observed at any acrolein concentration. Significant irregularities in the EKG

FUnless otherwise specified, FRC will refer to the dilution determined value. 
patterns were observed only during ventricular systole (QRS interval: $+20 \%$ ) and total ventricular activity (QT interval: $-11 \%$ ) in the $4.0 \mathrm{ppm}$ group (Table 6). No overt deformities, such as $T$ wave inversions, were observed in the electrocardiographic displays (Figure 7).

Lung Volumes. Vital capacity, manometrically determined during the QSC maneuver, dilution derived TLC and FRC, and their arithmetically computed components, RV, IC, ERV, and IRV were compared in control and acrolein exposed animals.

Neon dilution was the primary technique used for the determination of lung volume $\left(T L C_{d}\right.$ ) avoiding the confoundment of so-called "trapped" airspace. However, the concept of this non-communicating airspace was considered in the comparison of $F R_{d}$ (computed by $T_{L} C_{d}-I C$ ) to $F_{R C}$ (computed from Boyle's law). The latter measurement includes the "trapped" volume in the estimate of FRC. No significant changes from the control "FRC $\mathrm{b}_{\mathrm{b}}-\mathrm{FRC}_{\mathrm{d}}$ " volumes were observed after exposure to 0.4 and $1.4 \mathrm{ppm}$ acrolein (Figure 8). A $337 \%(p \leq 0.05)$ increase in this differential volume was seen in the $4.0 \mathrm{ppm}$ group. No attempt was made to determine the contribution, if any, of abdominal gas to the estimate of "trapped" air volume.

Figure 9 illustrates the impact of each level of acrolein on the divisions of lung volume. A significant increase in $R V(171 \%)$ and FRC (108\%) occurred in the $4.0 \mathrm{ppm}$ group, relative to control volumes. Similarly, significant changes were observed for TLC $(+49 \%)$, VC $(+27 \%)$, and IC $(+29 \%)$ in the $4.0 \mathrm{ppm}$ group. Figure 10 shows the RV, FRC, and VC after normalization to $\mathrm{TLC}_{\mathrm{d}}$. The $\mathrm{TLC}_{\mathrm{d}}$-normalized increases in $\mathrm{RV}$ and FRC were $91 \%(p \leq 0.0001)$ and $36 \%(p \leq 0.005)$ of control values, respectively. The normalized VC of the 4.0 ppm exposed rats was significantly less (13\%, $p<0.0001$ ) than that of controls. The extremely large FRC of the $4.0 \mathrm{ppm}$ 
groups ( $+108 \%$, Figure 9) was the primary contributor to the enlarged TLC and thus accounted for the relative decrease in VC/TLC.

"Parenchymal" Behavior and DLCO. Quasi-static compliance (QSC), reported as "steep" ( $\left.\mathrm{QSC}_{\mathrm{SS}}\right)$ or "chord" (QSC $\left.\mathrm{Cs}\right)$ slope, was increased 16\% (ns) and $34 \%(p<0.0003)$, respectively in the high dose group (Table 7$)$. If expressed as specific compliance (QSC/FRC) the degree of response at $4.0 \mathrm{ppm}$ was $-39 \%(p<.01)$ and $-29 \%$ (ns), steep and chord slopes, respectively. Regardless of expression, no significant changes were observed in these parameters at 0.4 and $1.4 \mathrm{ppm}$. Inspection of the actual QSC curves revealed a slight, but not statistically significant shift of the $0.4 \mathrm{ppm}$ curve to the right of the control curve (Figure 11). The curve for the intermediate exposure group was identical to the control curve. However, the $4.0 \mathrm{ppm}$ group exhibited a curve significantly shifted upward and to the left of control accounting for the increased slopes of the unadjusted curves (Table 7). Curve slope differences were eliminated by normalization to VC (Figure 12). The apparent dose related increase in $\mathrm{DLCO}_{\mathrm{sb}}$ (diffusion capacity of the lung for $\mathrm{CO}$ ) was reduced (e.g. $+45 \%, \mathrm{p}<0.0001$ ) to $-4 \%$ (ns) of control values in the $4.0 \mathrm{ppm}$ group after normalization to TLC (Table 7).

Distribution of Ventilation. Moment analyses of the multibreath $\mathrm{N}_{2}$ washout indicated that the distribution of ventilation was significantly altered in the $4.0 \mathrm{ppm}$ exposure group (Table 8 ). The ratio of the first $\left(\mathrm{M}_{1}\right)$ and second $\left(\mathrm{M}_{2}\right)$ weighted moments of lung $\mathrm{N}_{2}$ turnover to the overall lung $\mathrm{N}_{2}$ turnover $\left(M_{0}\right)$ are the moment ratios expressed in Table 8 . The typical control washout pattern exhibited three phases, suggesting three general lung compartments with distinct emptying patterns (Figure 13). The low and intermediate exposure groups retained a typical pattern with no 
apparent changes in compartmental emptying (Figure 13). However, the 4.0 ppm group appeared to have only two compartments, both emptying faster than any of the observed control rates (Figure 13).

Flow Volume Dynamics. The forced flow volume (MEFV) curves demonstrated significant acrolein related flow changes in the 0.4 and 4.0 ppm groups (Table 9; Figure 14). The flow volume curves for the $1.4 \mathrm{ppm}$ animals were essentially identical to those of the controls. However, the direction of the flow changes for the low and high dose groups relative to control values were diametrically opposite. After exposure to $0.4 \mathrm{ppm}$ the expiratory flow rates in the effort independent $1 \mathrm{imb}$ of the curve were significantly elevated. The PEF of the $0.4 \mathrm{ppm}$ group was only slightly higher $(+4.0 \%$, ns) than that of the controls (Table 9). The flow rates for the 4.0 ppm group were significantly depressed at a11 lung volumes. The slight convex pattern (away from the volume axis) typical of the effort independent region of control MEFV curves was significantly increased in the low dose group $\left(\triangle \mathrm{EFR}_{2} 5^{25}=184 \%, \mathrm{p}<0.001\right)$, and was unchanged for the intermediate and high dose animals (Table 9).

Upstream airway resistance $\left(R_{u s}\right)$ was calculated by relating maximum expiratory airflows to static lung pressures $\left(\mathrm{P}_{s t}\right)$ at $45 \%$ of lung volume. The $\mathrm{P}_{\mathrm{L}}$ recorded during the slow $\mathrm{QSC}\left(\mathrm{V} / \mathrm{P}_{\mathrm{L}}\right)$ maneuver was assumed to approximate $\mathrm{P}_{\mathrm{st}}$. Because the QSC technique required the imposition of a driving force, $P_{L}$ was adjusted to $0 \mathrm{~cm} \mathrm{H}_{2} \mathrm{O}$ at $\mathrm{RV}\left(-10 \mathrm{~cm} \mathrm{H} \mathrm{H}_{2} \mathrm{O}\right)$ to produce an analog of a self-driven $V / P$ curve. The $R_{u s}$ of the 0.4 ppm group was significantly reduced (15\%) relative to that computed for the control group (Table 10). The 4.0 ppm group exhibited a $129 \%$ increase in $R_{u s}$ (Table 10); the $1.4 \mathrm{ppm}$ group was unchanged from the controls. This apparent parabolic dose response relationship is consistent with the qualitative and 
quantitative (flow) changes observed for the forced flow volume maneuver. 
Table 5. Parameters of Spontaneous Breathing ${ }^{2}$ of Fischer 344 Rats Exposed to Acrolein

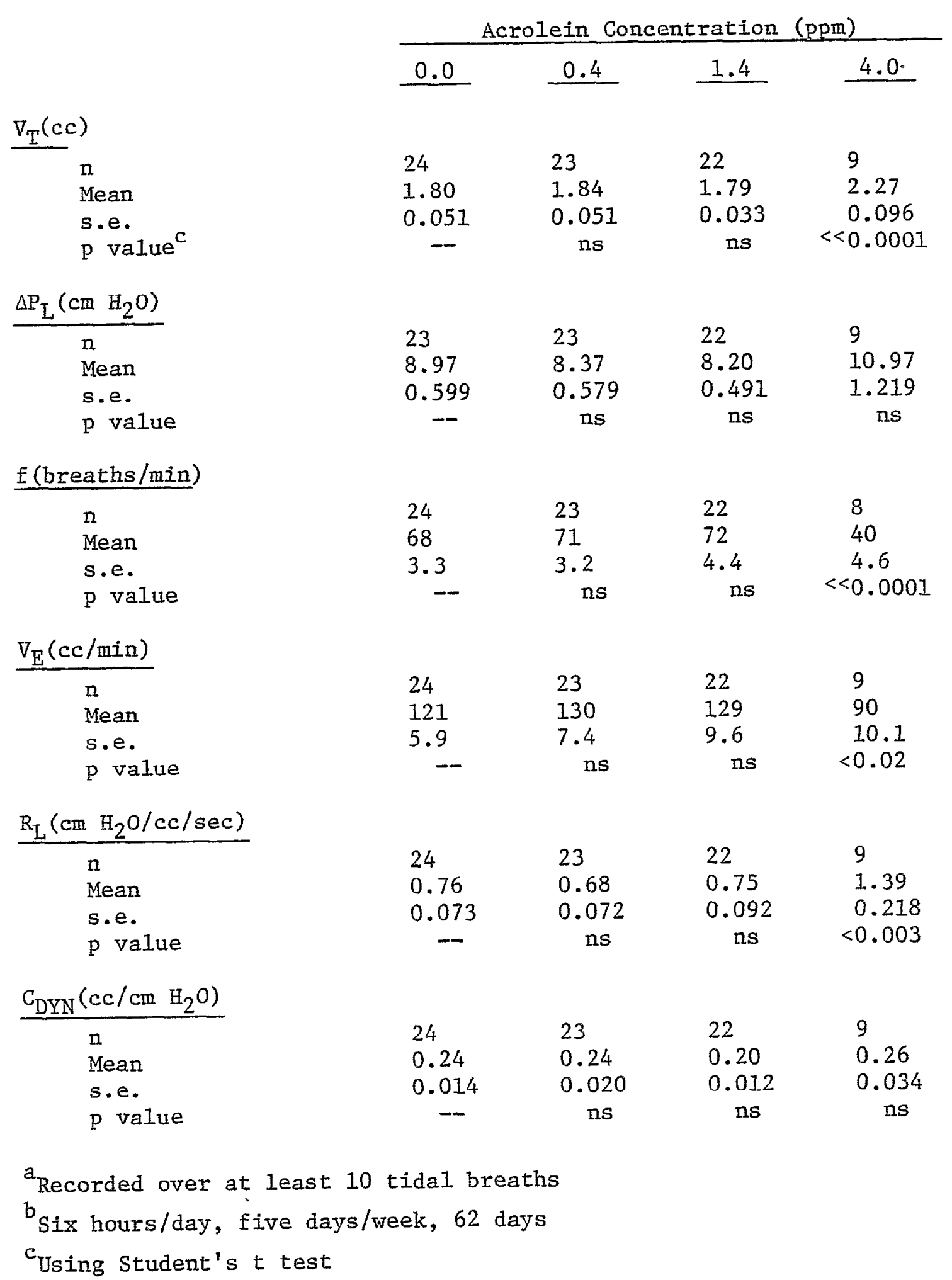




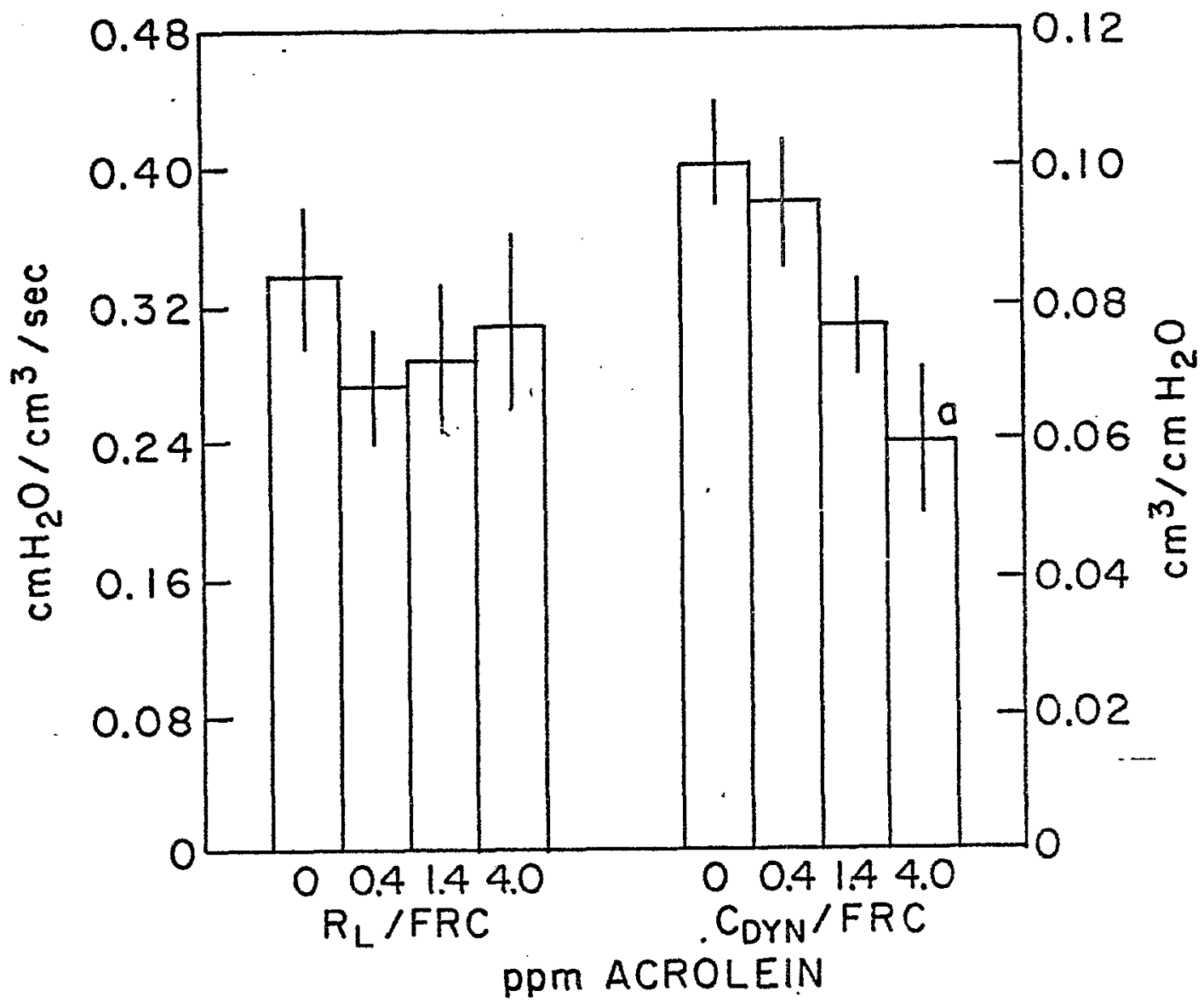

Figure 6: Pulmonary resistance $\left(R_{L}\right)$ and dynamic compliance $\left(\mathrm{C}_{\mathrm{DYN}}\right)$ normalized to the functional reserve capacity (FRC) of Fischer 344 rats exposed to acrolein for 62 days ( 6 hours/day, 5 days/week). The number of rats in the 0.0 , $0.4,1.4$, and 4.0 ppm exposure groups was 24, 24,21 , and 8 , respectively.

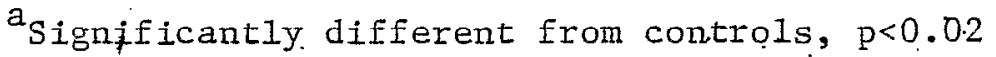
using student's t test. 
Table 6. Analysis of Electrocardiogram ${ }^{2}$ Time Intervals of Fischer 344 Rats Exposed to Acrolein

n

$$
\frac{0.0}{23}
$$$$
395
$$

p value ${ }^{c}$

$\underline{P-R \quad(s e c)}$

Mean

s.e.

$P$ value

QRS (sec)

Mean

s.e.

$\mathrm{p}$ value

$\mathrm{Q}-\mathrm{T}$ (sec)

Mean
s.e.
p value

Acrolein Concentration (ppm)

$\begin{array}{lll}0.4 & \frac{1.4}{22} & \frac{4.0}{9}\end{array}$

387

10

ns

0.0521

0.00111

$\begin{array}{ll}0.0548 & 0.0562 \\ 0.00124 & 0.00080 \\ \text { ns } & <.05\end{array}$

0.0210

0.00075

$<.001$

0.00051

--
0.0680
0.00211
$-$
0.0672
0.00195
ns

$$
\begin{array}{r}
390 \\
12 \\
\text { ns }
\end{array}
$$

377

12

ns

0.0551

0.00109 ns
0.0170
0.00071
ns

Data taken from single series of cardiac impulses prior to pulmonary function tests.

${ }^{b}$ Six hours/day, five days/week, 62 days.

CUsing Student's t-test. 


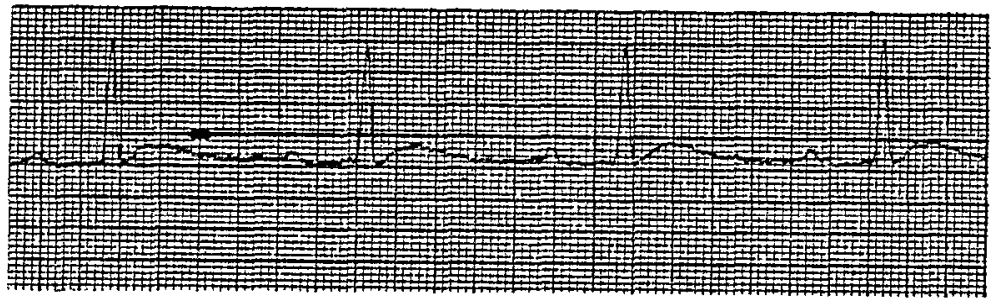

CONTROL

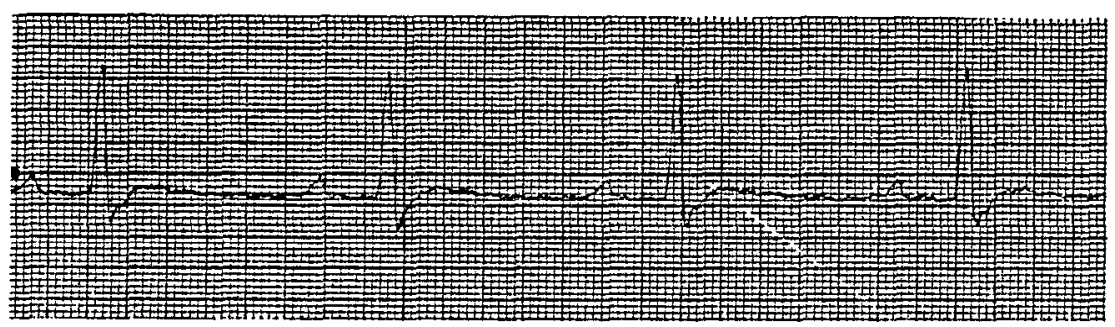

0.4 ppm ACROLEIN

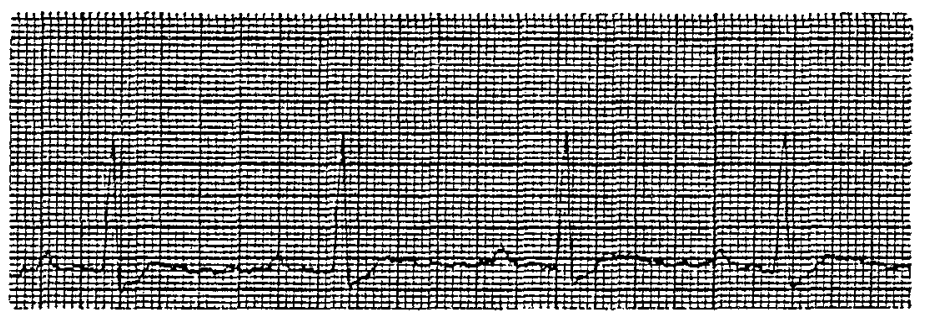

4.0 pPm ACROLEIN

Figure 7: Representative electrocardiograms of Fischer 344 rats exposed to $0.0,0.4$, and 4.0 ppm acrolein for 62 days ( 6 hours/day, 5 days/ week). 




Figure 8: Trapped air in the lungs of Fischer 344 rats exposed to acrolein for 62 days ( 6 hours/day, 5 days/ week). Data presented are the means (ts.e.) of 24 control, $230.4 \mathrm{ppm}, 211.4 \mathrm{ppm}$, and $84.0 \mathrm{ppm}$ acrolein exposed rats.

$\mathrm{FRC}_{\mathrm{b}}$ : Functional reserve capacity determined by Boyle's Law.

$\mathrm{FRC}_{\mathrm{d}}$ : Functional reserve capacity determined by dilution.

a: Significantly different from controls, $p<0.001$ using Student:s t-test. 


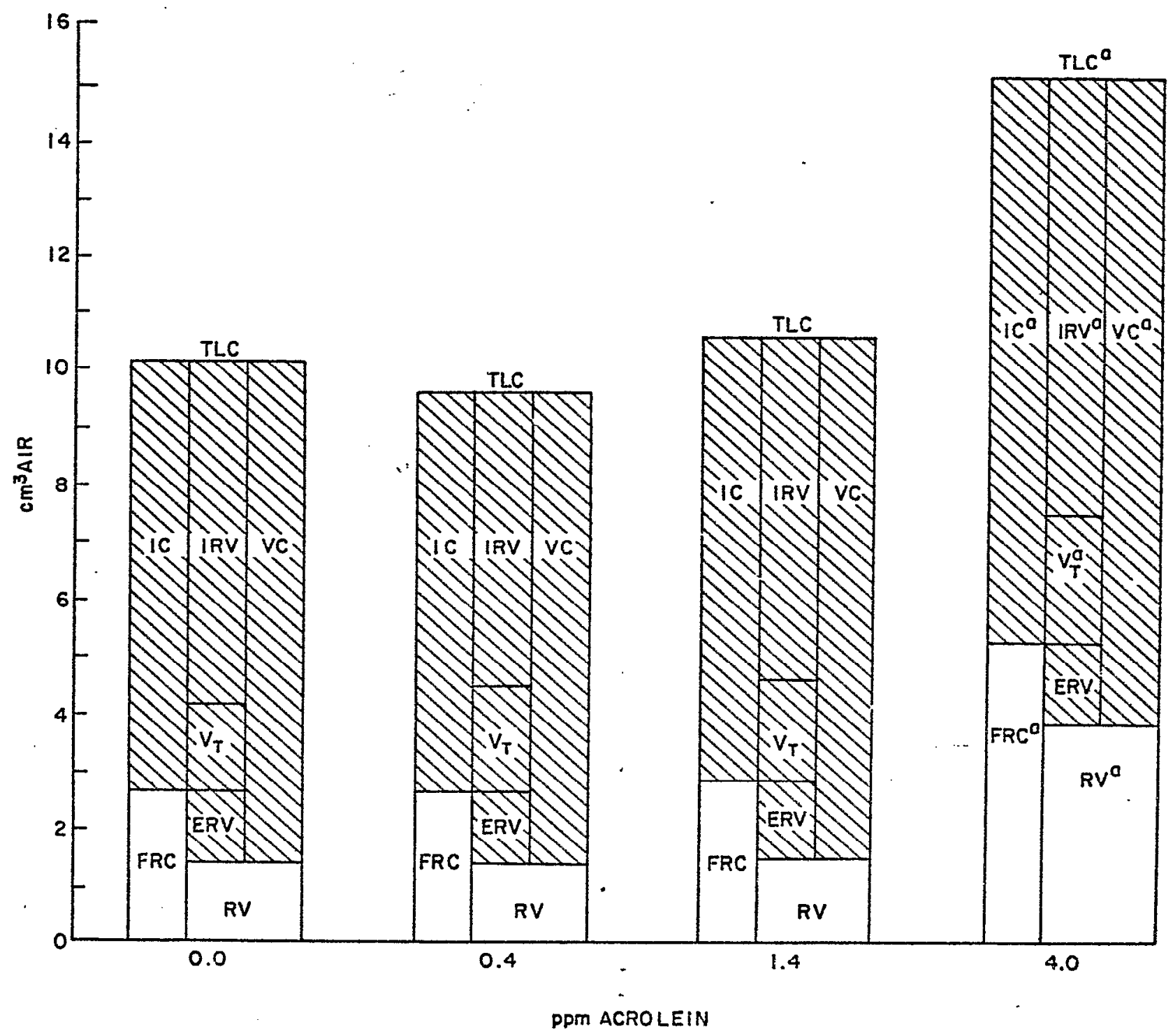

Figure 9: Divisions of lung volumes in Fischer 344 rats exposed to acrolein for 62 days ( 6 hours/day, 5 days/week).

ERV: Expiratory reserve volume

FRC: Functional reserve capacity

IC: Inspiratory capacity

IRV: Inspiratory reserve volume

RV: Residual volume

VC: Vital capacity

$\nabla_{T}:$ Tidal volume

TLC: Total lung volume

a: Significantly different from controls, $p<0.0001$, using student's $t$ test. 


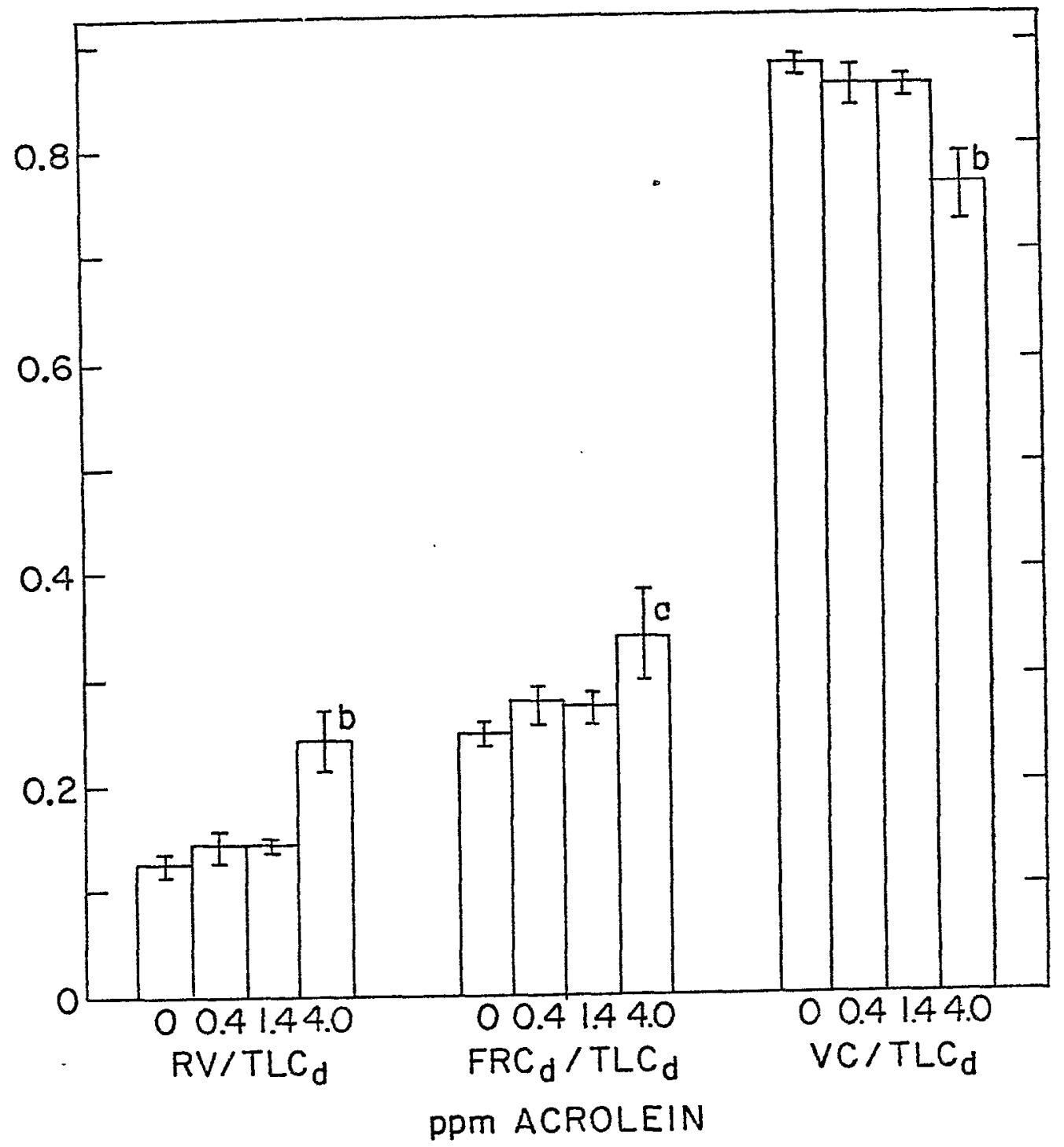

Figure 10: Normalized lung volumes of Fischer 344 rats exposed to acrolein for 62 days ( 6 hours/day, 5 days/week). Data presented are the means ( + s.e.) of $24,24,21$, and 8 , control, $0.4 \mathrm{ppm}, 1.4 \mathrm{ppm}$, and $4.0 \mathrm{ppm}$ acrolein exposed rats, respectively.

FRC: Functional reserve capacity

RV: Reserve volume

TLC: Total lung volume

VC: Vital capacity

a: Significantly different from controls, $\mathrm{p}<0.005$ using Student's t-test.

$\mathrm{b}$ : Significantly different from controls, $\mathrm{p} \leq 0.0001$ using Student's t-test. 
Table 7. Indices of Parenchymal Damage in Fischer 344 Rats Exposed to Acrolein ${ }^{a}$

Acrolein Concentration (ppm)

\begin{tabular}{llll}
0.0 & 0.4 & 1.4 & 4.0 \\
\hline
\end{tabular}

$\mathrm{QSC}_{\mathrm{SS}}$

$\mathrm{n}$

Mean

s.e.

p value

$\mathrm{QSC}_{S S} / \mathrm{FRC}^{\mathrm{C}}$

n

Mean

s.e.

$\mathrm{p}$ value

QSC

cs

$\mathrm{n}$

Mean

s.e.

$\mathrm{p}$ value

$\underline{Q S C_{C S} / F R C}$

n

Mean

s.e.

$\mathrm{p}$ value

DLCO

(sb)
23

0.83

.049

$-$

24

0.36

.031

$-$

23

0.56

.027

--

23

0.24

.019

$-$

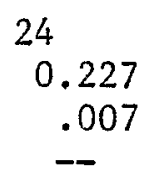

$\mathrm{DLCO}_{(\mathrm{sb})} / \mathrm{TLC}^{\mathrm{C}}$ n

Mean

s.e.

$p$ value

n

Mean

s.e.

$p$ value
24

0.023

.001
23

0.73

.029

ns

23

0.30

.029

ns

23

0.56

.023

ns

23

0.23

.021

ns

23

0.245

.006

ns
23
0.025
.000
$<.01$

22

0.77

.048

ns

21

0.29

.022

ns

9

0.22

.035

$<0.01$

${ }^{a}$ Six hours/day, five days/week, 62 days

$b_{\text {Using Student's t-test }}$

CDilution volumes 


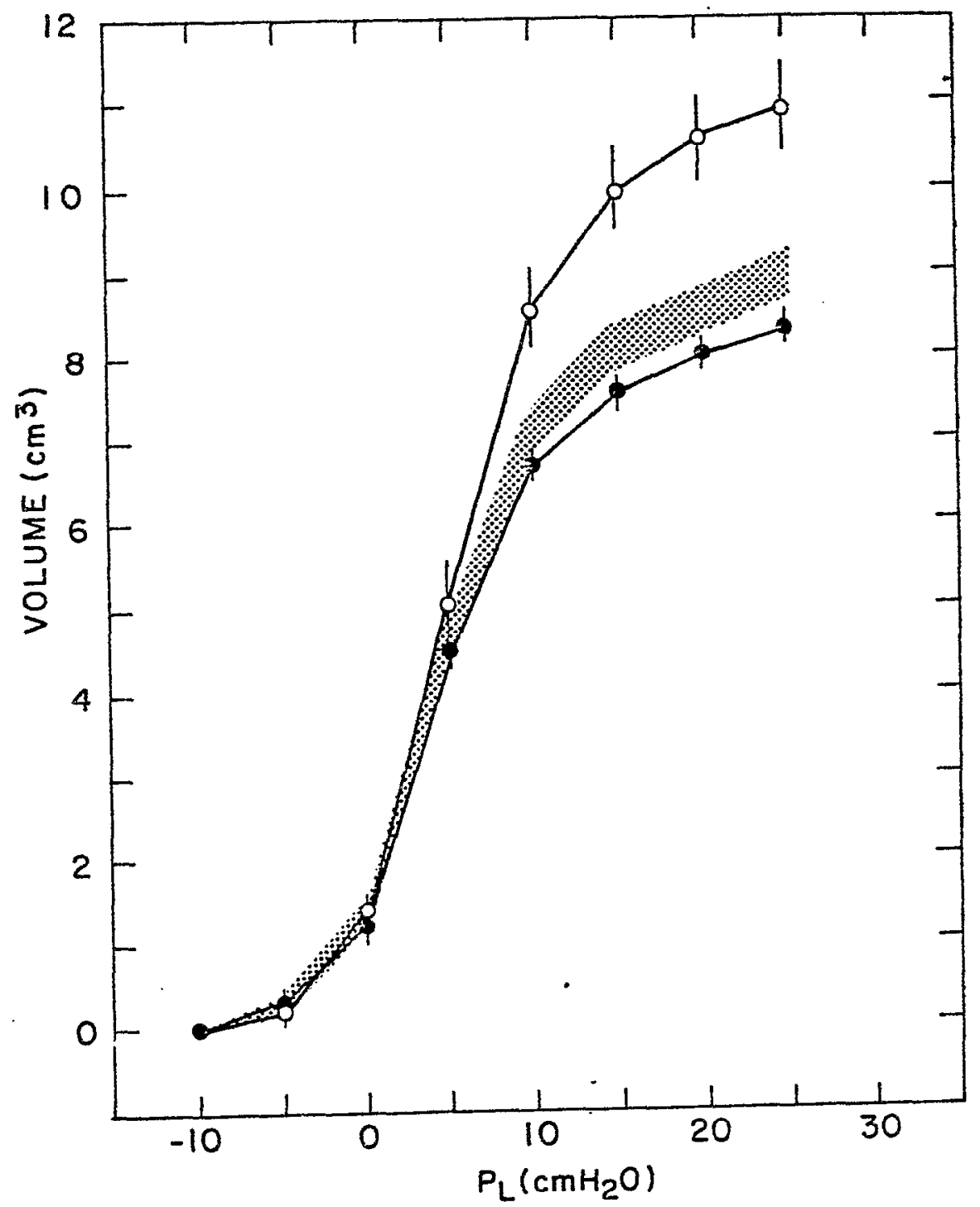

Figure 11: Quasi-static compliance of Fischer 344 rats exposed to acrolein for 62 days ( 6 hours/day, 5 days/week). The means and s.e. bars of 24 controls, and $211.4 \mathrm{ppm}$ exposed animals lie within the shaded area. The data from 23 rats exposed to $0.4 \mathrm{ppm}$ acrolein (-๑) and 9 rats exposed to $4.0 \mathrm{ppm}$ acrolein $(-0-)$ are plotted separately. 




Figure 12: Quasi-static compliance as a function of vital capacity. of Fischer 344 rats exposed to acrolein for 62 days ( 6 hours/day, 5 days/week). The means and s.e. bars of 24 control and 231.4 ppm rats lie within the shaded parea. The data from 23 rats exposed to $0.4 \mathrm{ppm}$ acrolein (- - ) and 9 rats exposed to 4.0 ppm acrolein $(-\circ-)$ are plotted separately. 
Table 8. Moment Analysis of Multibreath $\mathrm{N}_{2}$ Washout in Fischer 344 Rats Exposed to Acrolein

Acrolein Concentration (ppm)

$\sum_{n=23}^{0.0} \quad \frac{0.4}{n=22} \quad \frac{1.4}{n=18} \quad \frac{4.0}{n=8}$

$\mathrm{M}_{1} / \mathrm{M}_{0}$

Mean

s.e.

p value

$\underline{M_{2} / M_{0}}$

Mean

s.e.

$p$ value

$\begin{array}{cccc}12.43 & 12.64 & 12.13 & 10.18 \\ .368 & .277 & .390 & .186 \\ -- & \mathrm{ns} & \mathrm{ns} & <.05\end{array}$

290.34

13.591

--
277.01

14.325

ns
214.28

45.213

$<.05$

${ }^{a}$ Six hours/day, five days/week, 62 days.

$b_{\text {Using Student's t-test. }}$

$\mathrm{M}_{0}$ : Total area under the $\mathrm{N}_{2}$ washout curve for 50 breaths.

$$
\begin{aligned}
M_{0}= & \sum_{j=1}^{50} x_{j} \\
M_{1}= & \sum_{j=1}^{50} j \cdot x_{j} \\
M_{2}= & \sum_{j=1}^{50} j^{2} \cdot x_{j} \\
& j=5 \text { (dilution no. }+1)
\end{aligned}
$$



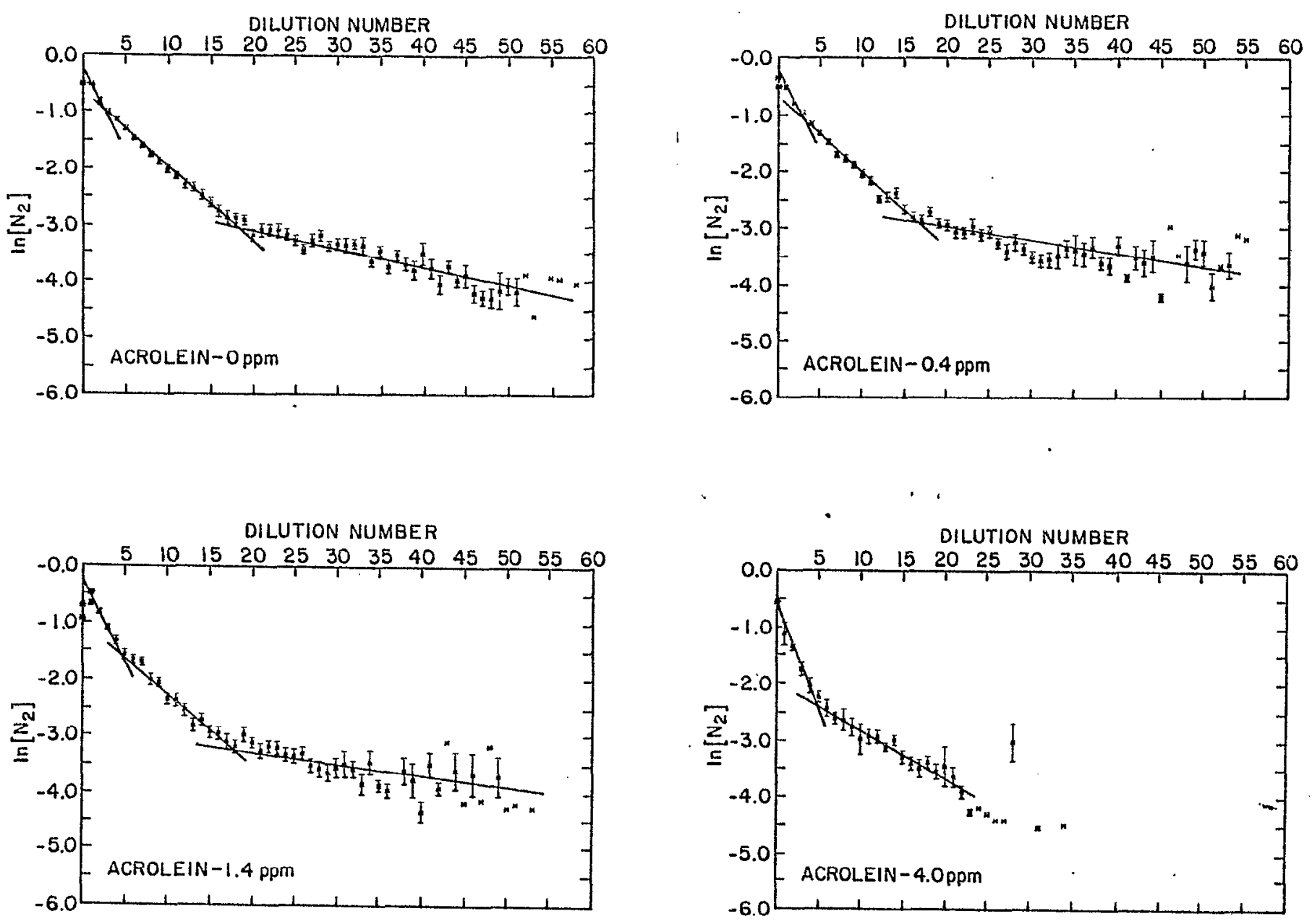

Figure 13: Multibreath $\mathrm{N}_{2}$ washout curves for control and acrolein exposed Fischer 344 rats. Each graph is the mean (ts.e.) In of the end-expiratory $\mathrm{N}_{2}$ concentration versus the dilution number $\left[\frac{\text { breath } \# \cdot V_{T}}{F R C}\right]$. The slope of the lines approximates the time constant for $\mathrm{N}_{2}$ turnover in each lung compartment. 
Table 9. Statistical Analysis of Normalized Data Points on the MEFV Curve of Fischer 344 Rats Exposed to Acroleina

Acrolein Concentration (ppm)

$\begin{array}{llll}0.0 & 0.4 & 1.4 & 4.0 \\ n=24 & n=23 & n=9\end{array}$

PEF(VC/sec)

Mean

s.e.

p value

$\mathrm{EFR}_{50}(\mathrm{VC} / \mathrm{sec})$

Mean

s.e.

p value

$\mathrm{EFR}_{25}(\mathrm{VC} / \mathrm{sec})$

Mean

s.e.

$\mathrm{p}$ value

$\mathrm{EFR}_{10}(\mathrm{VC} / \mathrm{sec})$

Mean

s.e.

$p$ value

$\triangle \mathrm{EFR}_{25}(\mathrm{VC} / \mathrm{sec})$

Mean
s.e.
p value

${ }^{\mathrm{a}} \mathrm{Six}$ hours/day, five days/week, 62 days.

busing Student's t-test.

$\begin{array}{cccc}11.42 & 12.65 & 11.25 & 7.63 \\ .327 & .403 & .313 & .426 \\ - & <.025 & \text { ns } & <.001\end{array}$

\section{9}

.36

11.6

.41

$<.0025$

10.2

.36

5.8

ns

$<.0001$

$\begin{array}{ll}5.7 & 7.8 \\ .36 & .39 \\ -- & .0002\end{array}$

6.0

.44

2.8

ns

.60

$<.0001$

$\begin{array}{ll}2.7 & 3.9 \\ .28 & .27 \\ - & .0030\end{array}$

3.0

0.89

.34

ns

.291

$<.0001$
0.70
.244

1.99

.241

$<.0006$

0.89

$-0.17$

.313

ns .371 ns 


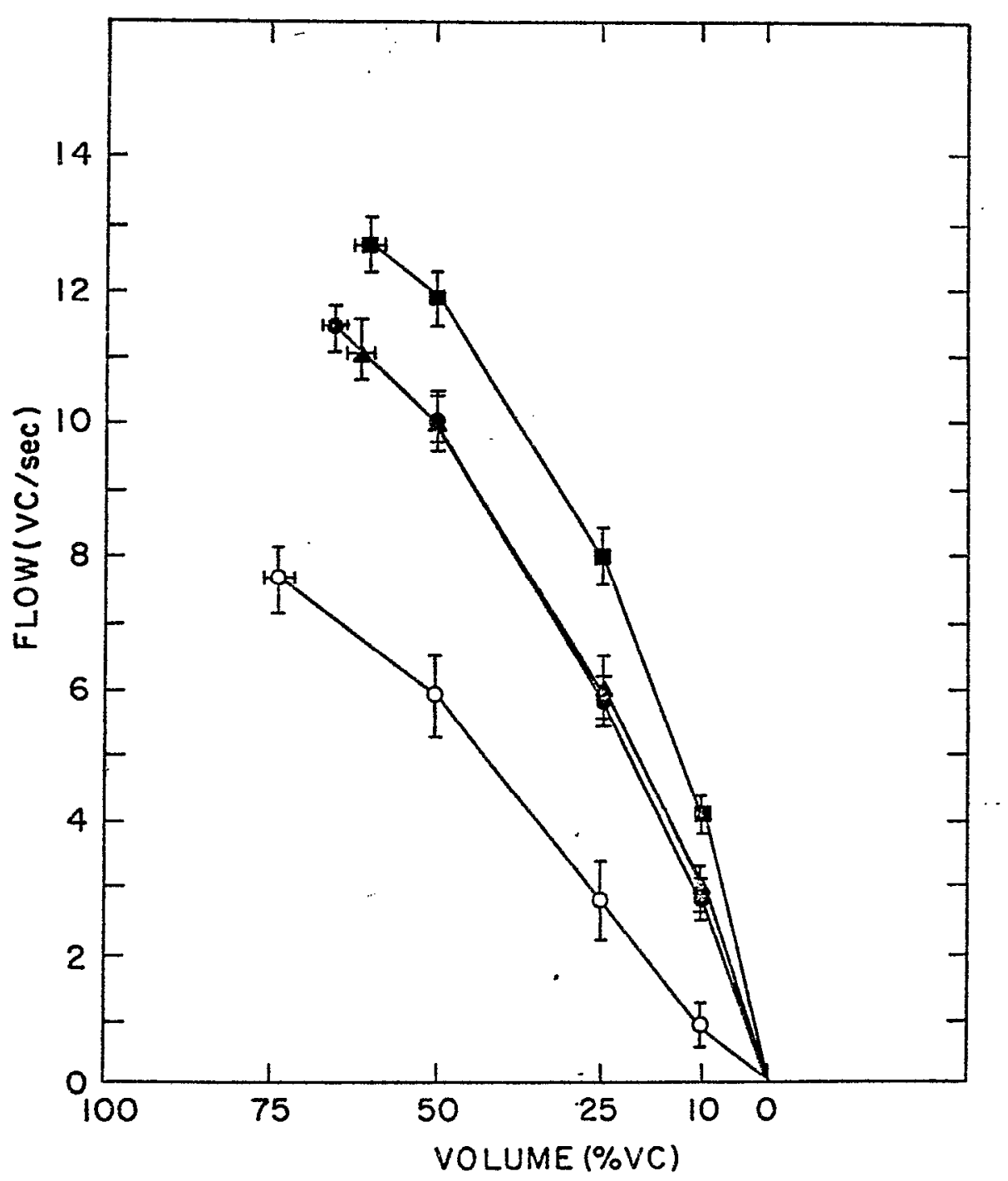

Figure 14: Maximum expiratory flow volume curves of Fischer 344 rats exposed to acrolein for 62 days ( 6 hours/day, 5 days/week).

- control, $\mathrm{n}=24$

- $0.4 \mathrm{ppm}$ acrolein, $\mathrm{n}=23$

- 1.4 ppm acrolein, $n=22$

- 4.0 ppm acrolein, $n=9$ 
Table 10. Analysis of Upstream Airway Resistance ${ }^{a}$ in Fischer 344 Rats Exposed to Acrolein

Acrolein Concentration (ppm)

$\begin{array}{llll}0.0 & 0.4 & 1.4 & 4.0 \\ n=24 & n=23 & n=21 & n\end{array}$

$\%$ VC (FEV)

Mean

s.e.

p value

$\underline{\mathrm{V}(\mathrm{cc} / \mathrm{sec})}$

Mean

s.e.

$\mathrm{p}$ value

$\mathrm{P}_{\mathrm{L}} \mathrm{Stat}\left(\mathrm{cm} \mathrm{H} \mathrm{H}_{2} \mathrm{O}\right)$

Mean

s.e.

p value

$\mathrm{R}_{\text {us }}\left(\mathrm{cm} \mathrm{H}_{2} \mathrm{O} / \mathrm{cc} / \mathrm{sec}\right)$

Mean

s.e.

$p$ value
0.182

0.005

56.1

0.70

ns

80.7

2.43

--

4.40

0.218

--

$$
\begin{aligned}
& 3.66 \\
& 0.236 \\
& <.05
\end{aligned}
$$

0.154
0.006
$<.005$
55.8

0.53

ns

84.1

3.49

ns

46.8

9.28

$<.001$
55.7

1.59

ns

Upstream airways are those distal or upstream of the theoretical equal pressure point achieved during forced expiration (MEFV).

${ }^{\mathrm{b}}$ Six hours/day, five days/week, 62 days.

$\mathrm{c}_{\text {Using Student's t-test. }}$ 
Pathology Data

Selected tissues from three groups of animals were submitted to EPL for pathological examination. Group one consisted of animals found dead or moribund before completion of 62 exposure days. Iungs from all the animals in this group were sent to EPL which randomly selected specimens for examination. All animals in this group were from the $4.0 \mathrm{ppm}$ acrolein chamber. The second group consisted of eight male animals from each exposure level designated as pathology animals. However, only five of the eight designated rats survived in the $4.0 \mathrm{ppm}$ chamber. Group 3 was made up of the respiratory physiology animals. Selected tissues from all the animals used in the pulmonary assessment tests were submitted for pathological examination. These were studied to determine if possible correlations could be drawn between the pulmonary function and the pathology of individual animals. These specimens also provided an opportunity to determine whether or not the pulmonary function test regime resulted in any structural changes detectable at the light microscopy level.

Dead and Moribund Animals. Lungs of animals found dead or moribund displayed severe, acute bronchopneumonia; however, several areas of the lungs appeared unaffected. There was focal alveolar edema with sloughed cells in the bronchi and bronchioles. Most of the airways were actually plugged which would result in anoxia and death, even though there were healthy areas in the lungs. In addition to the pulmonary changes, there was tracheal edema with errosion of the mucosal epithelium.

Pathology Animals. Lungs of control rats displayed minimal to slight proliferations of lymphoid cells (Table 11) associated with a low grade chronic murine pneumonia. The presence of a slight acute or subacute alveolitis in some of these animals suggested a recent bacterial infection. 
In a single animal there was an exacerbation of alveolitis to moderate acute bronchopneumonia and bronchitis. These changes were not severe in most cases and are mentioned for the purpose of baseline pulmonary pathology. Changes in organs other than the respiratory tract were negligible with the exception of focal mononuclear infiltrates in the livers of two rats (Table 11).

Rats exposed to 0.4 and $1.4 \mathrm{ppm}$ acrolein had minimal to slight pulmonary lymphoid proliferations (Table 11) characteristic of chronic murine pneumonia. Rats from these exposure groups did not display pulmonary lesions attributable to acrolein exposure. Changes in the nonrespiratory organs appeared incidental and were mild lesions commonly seen in laboratory rodents.

In the $4.0 \mathrm{ppm}$ group, exposure related pulmonary lesions were seen in three out of five animals (Table 11); namely, bronchiolar epithelial necrosis and sloughing with a build-up of bronchiolar edema fluid and macrophages. Changes in the nonrespiratory organs including slight testicular atrophy in one rat and spleenic capsular fibrosis in another (Table 11) were considered incidental findings.

Respiratory Physiology Animals. Changes in the lungs of the control group were characteristic of a mild, low grade chronic pneumonia with focal acute or subacute alveolitis such as that described in the pathology animals. Again, these changes were not severe.

Lungs of animals in the 0.4 ppm respiratory physiology group, for the most part, resembled those of the controls. Three of the 23 rats in this group had slightly increased numbers of alveolar macrophages (Table 12), but this was not considered to be exposure related.

In the $1.4 \mathrm{ppm}$ group, three animals (Table 12; 5703, 5747, and 5786) appeared to have an exposure-related pulmonary lesion which consisted of 
bronchiolar epithelial necrosis and sloughed cells laying free in the lumen. Acrolein exposure resulted in increased numbers of alveolar macrophages and enhanced the degree of type II cell hyperplasia. Other changes associated with chronic murine pneumonia or a focal acute or subacute alveolitis appeared somewhat enhanced by acrolein exposure.

Lungs from the $4.0 \mathrm{ppm}$ respiratory physiology group had lesions which appeared to be related to acrolein inhalation (Table 12). These included: 1) bronchiolar epithelial necrosis and sloughing, 2) bronchiolar edema with macrophages, and 3) focal edema. The numbers of alveolar macrophages also appeared to be somewhat increased. Edema in the trachea and peribronchial lymph nodes also appeared to be exposure related in this group as did acute rhinitis.

For the purpose of exploring possible correlations with the pulmonary function data and the lung composition data from individual animals, the severity of the pulmonary pathology in all of the respiratory physiology animals was scored. The values in Table 13 are the sums of the subjective values given to the various pulmonary lesions for each animal in Table 12 . Also provided in Table 13 is the overall ordinal rank of each respiratory physiology animal. The frequency of each pathology score for the animals in each of the four exposure groups has been plotted in Figure 15. Although mild histological changes were observed in the control and $0.4 \mathrm{ppm}$ animals, a dose related increase in pathological change was clearly evident at the higher exposure concentrations. Also, the broad range of intra-group variability in response to 1.4 and $4.0 \mathrm{ppm}$ acrolein is apparent in Figure 15. Many of the animals in the $1.4 \mathrm{ppm}$ group had scores which overlapped those of the controls, while three of the nine $4.0 \mathrm{ppm}$ animals showed no histopathologic changes. The Kruskal1-Wallis one way analysis of variance indicated a significant difference among the pathology scores of the four 
exposure groups $(p<0.0039)$. A multiple comparison procedure for nonparametric data (30) was employed to compare the individual groups. To maintain the appropriate confidence interval, the selected probability level of significance was divided by the number of comparisons (six). If $p<0.0083(0.05 \div 6)$ was selected as the level of significance, only the 0.4 group differed from the 1.4 and $4.0 \mathrm{ppm}$ animals, reflecting the slightly lower than control scores in the $0.4 \mathrm{ppm}$ group. However, if a $\mathrm{p}<0.0167$ $(0.10 \div 6)$ was assumed significant, the scores of the 1.4 and $4.0 \mathrm{ppm}$ animals were statistically greater than those of both the control and the 0.4 groups. 
Brookhaven National Laboratory National Toxicology Program Acrolein Study

Male Rats

Controls

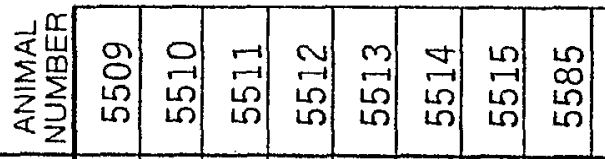

Low Dose $-0.4 \mathrm{ppm}$

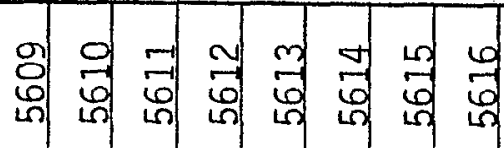



E P L Experimental Pathology Laboratories, Inc.
Key: $P=$ Present
1 = Minimal
$5=$ Severe/High

$N=$ No Section

$2=$ Slight
$I=$ Incomplete Section
$A=$ Autolysis $\quad X=$ Not Remarkable

$3=$ Moderate $4=$ Moderately Severe/High 
Brookhaven National Laboratory National Toxicology Program

Acrolein Study

Male Rats

Controls

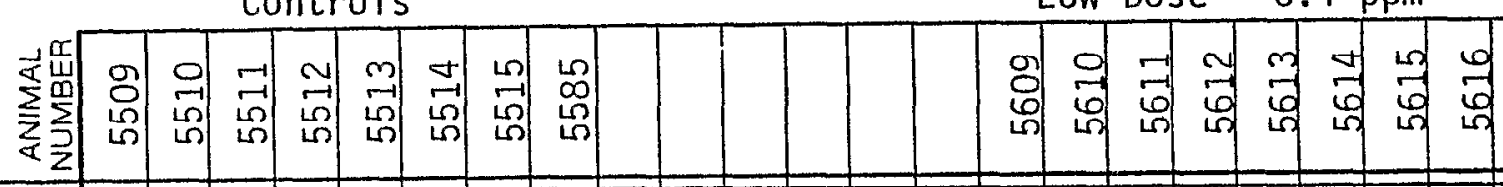

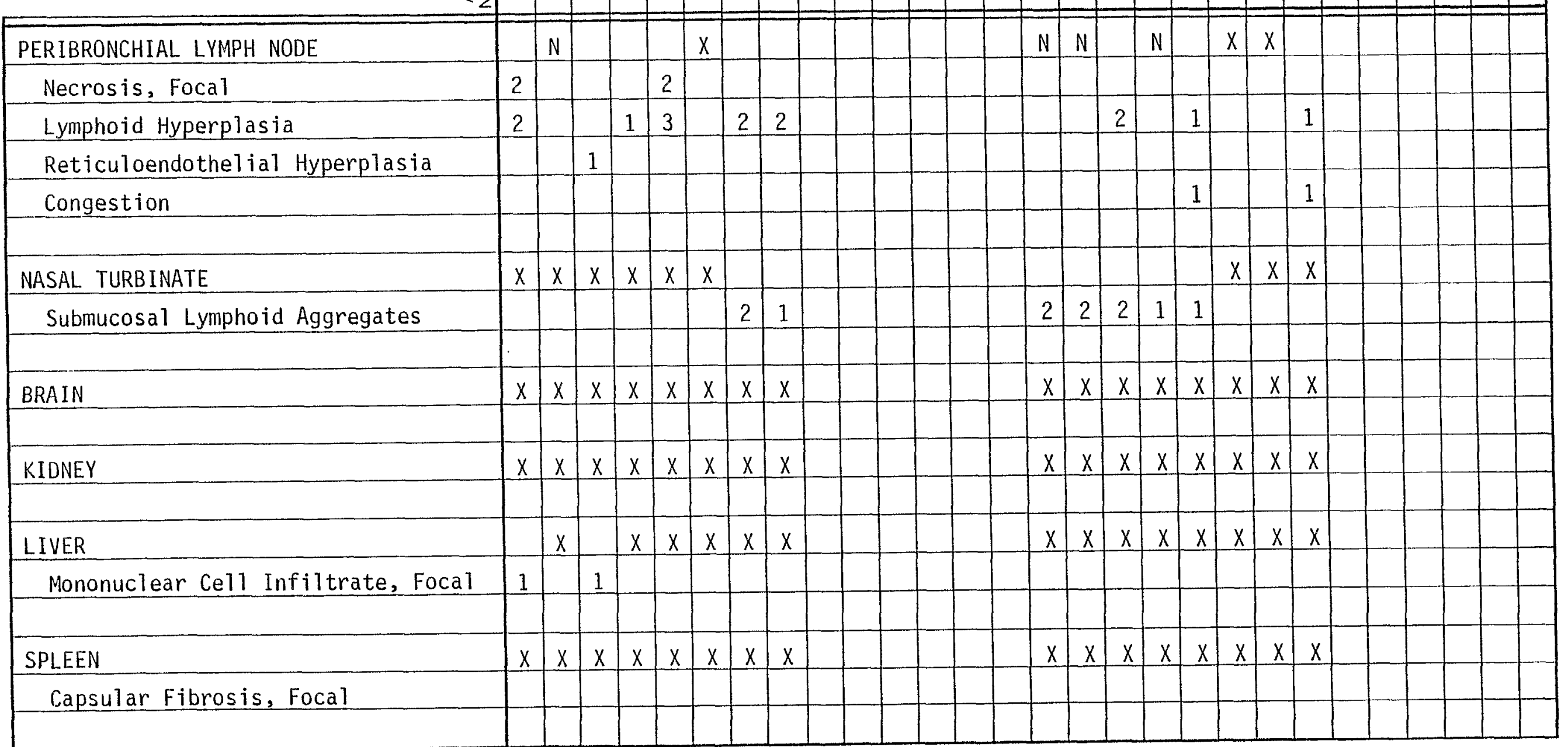


Brookhaven National Laboratory

National Toxicology Program

Acrolein Study

Male Rats

Controls

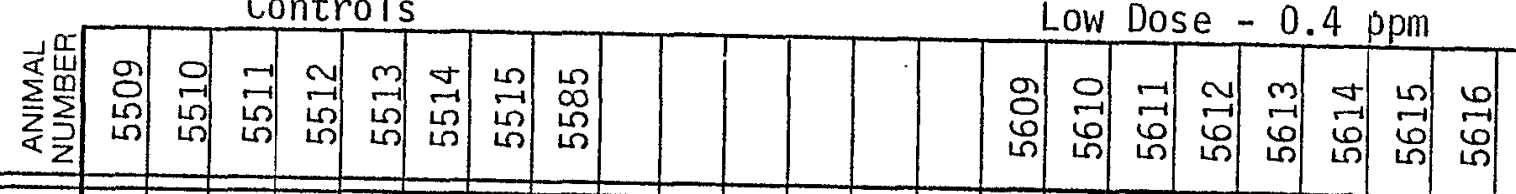

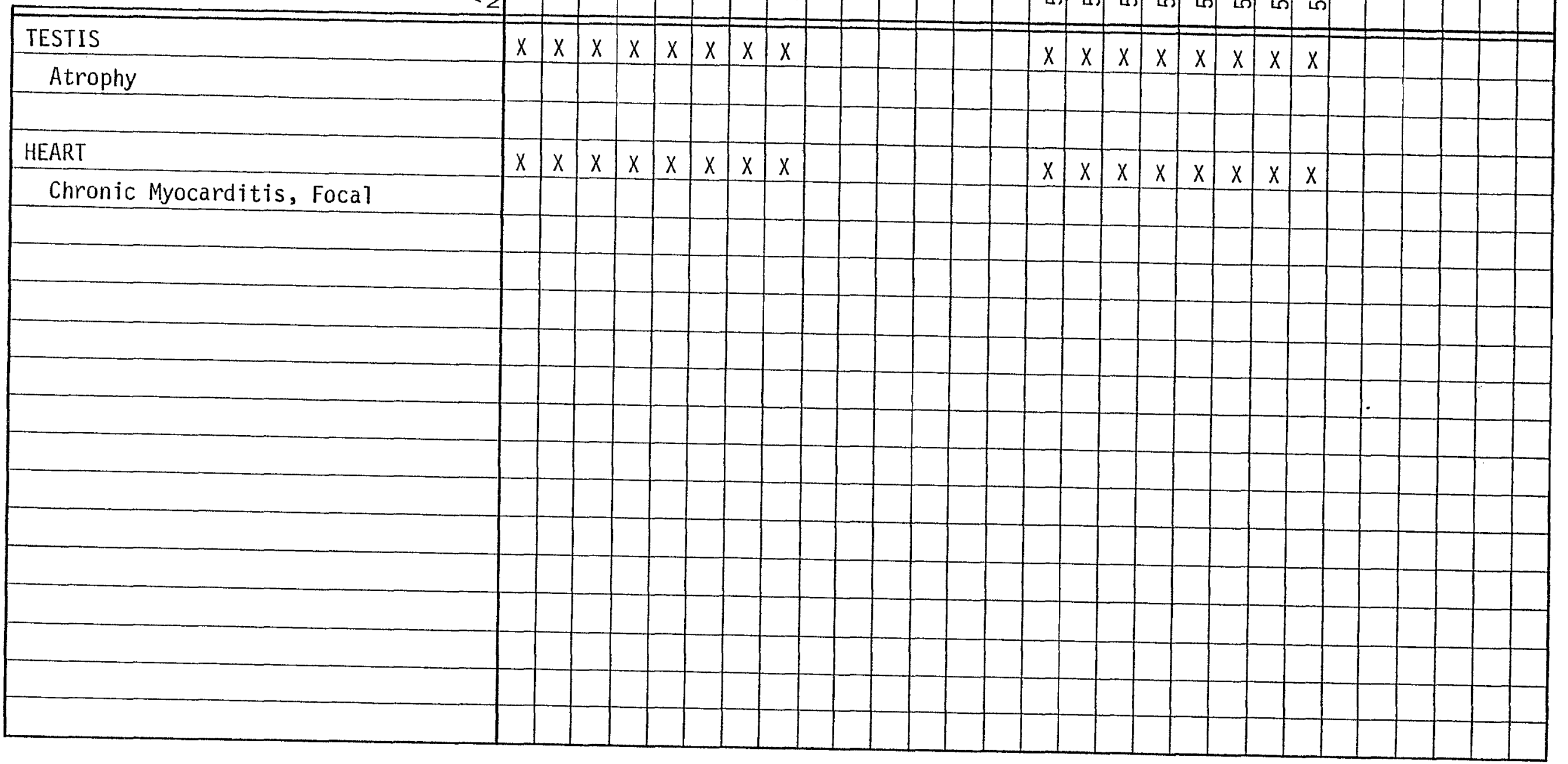

Key: $P=$ Present $\quad N=$ No Section

$1=$ Minimal

5 = Severe/High
$2=$ Slight

$=$ Incomplete Section
$A=$ Autolysis

$3=$ Moderate

$x=$ Not Remarkable

$4=$ Moderately Severe/High 


\section{TABLE 11: PATHOLOGY ANIMALS}

Brookhaven National Laboratory National Toxicology Program Acrolein Study

Male Rats
HISTOPATHOLOGY INCIDENCE TABLE

Intermediate Dose $-1.4 \mathrm{ppm}$

High Dose - $4.0 \mathrm{ppm}$

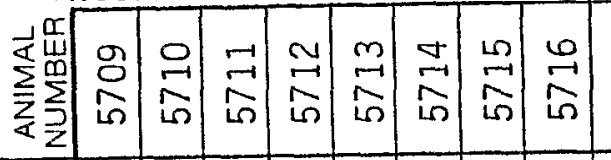

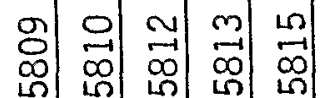

\section{$\overline{\text { LUNG }}$}

Lymphoid Proliferations,

Perivascular and Peribronchiolar

$\begin{array}{lllllllll}1 & 2 & 1 & 1 & 2 & 2 & 1 & 1\end{array}$

Alveolitis, Focal, Acute/Subacute

Type II Cell Hyperplasia

Granuloma, Focal

Bronchitis, Acute

Bronchopneumonia, Acute

Edema, Focal

Pleuritis, Foca]

Bronchiolar Epithelial Necrosis

and Sloughing

Bronchiolar Edema and Macrophages

TRACHEA

Chronic Tracheitis

\section{\begin{tabular}{llllll}
2 & 1 & 1 & 2 & 1 \\
\hline & &
\end{tabular} \\ $2 \quad 1$}

\section{2}

2

13

\begin{tabular}{ll|l}
2 & 3 & 1
\end{tabular}

\begin{tabular}{l|l} 
E P : & \\
\hline Experimental Pathology Laboratories, Inc.
\end{tabular}

Key: $P=$ Present

$1=$ Minimal

$5=$ Severe/High
$N=$ No Section

2 = Slight

$2=$ Slight
$I=$ Incomplete Section 
Brookhaven National Laboratory National Toxicology Program Acrolein Study

Male Rats

Intermediate Dose - $1.4 \mathrm{ppm}$

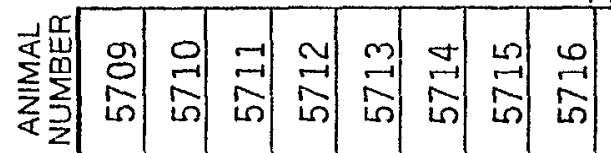

High Dose $-4.0 \mathrm{ppm}$

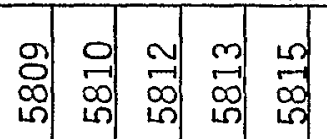

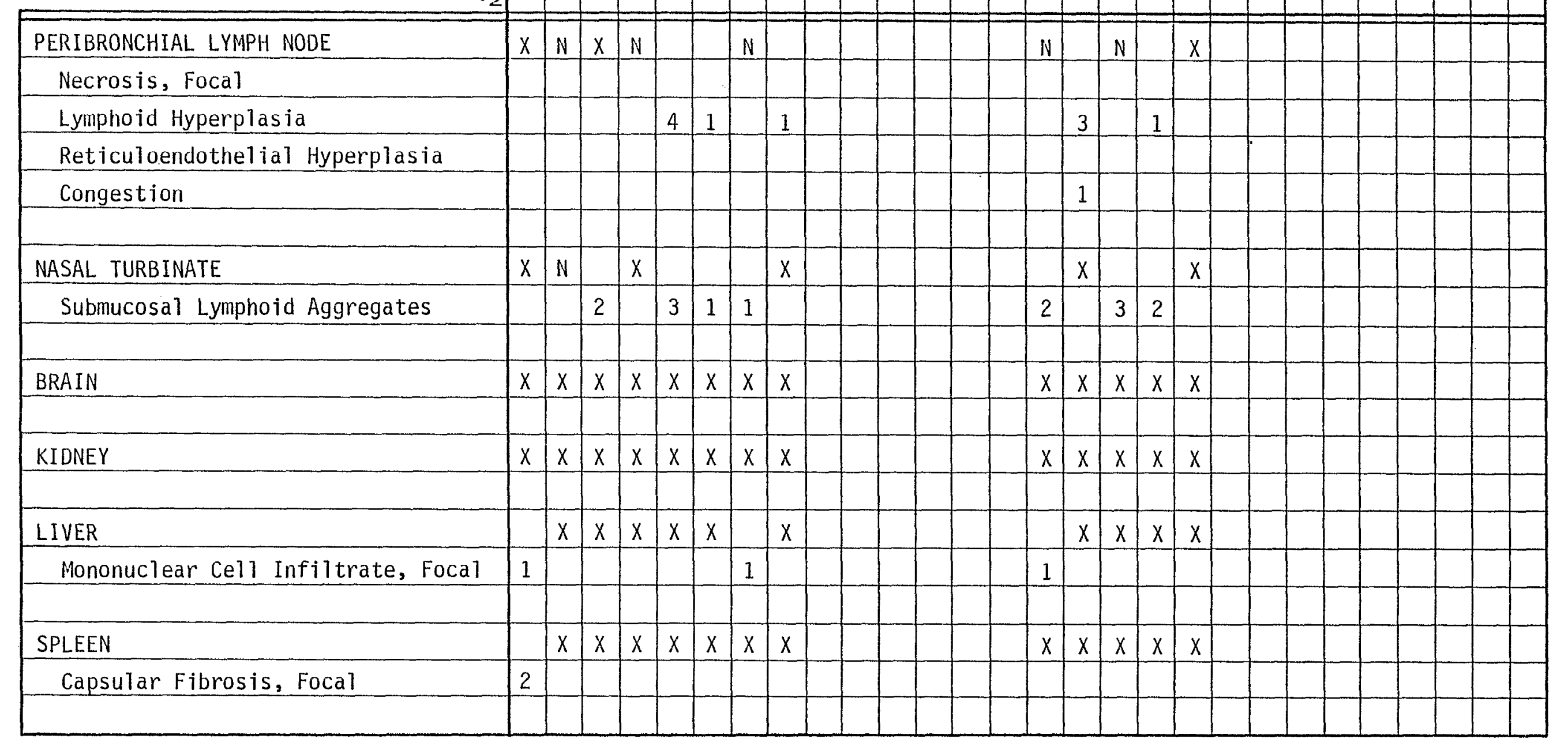

E P L

Experimental Pathology Laboratories, Inc.

$$
\text { Key: } \begin{aligned}
P & =\text { Present } \\
1 & =\text { Minimal }
\end{aligned}
$$

$5=$ Severe/High

$N=$ No Section

2 = Slight

$I=$ Incomplete Section
$A=$ Autolysis

3 = Moderate 
TABLE 11: PATHOLOGY ANIMALS

Brookhaven National Laboratory National Toxicology Program

Acrolein Study

Male Rats

\section{HISTOPATHOLOGY INCIDENCE TABLE}

Intermediate Dose - 1.4 ppm

High Dose - 4.0 ppm

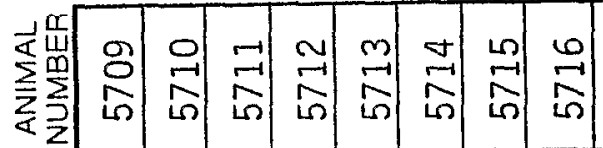

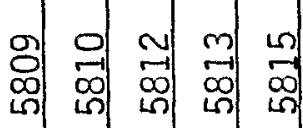

$x \quad x \quad x \quad x \quad x$

$x \times x \quad x \quad x$

\begin{tabular}{|l} 
HEART \\
\hline Chronic Myocarditis, Focal
\end{tabular}

\begin{tabular}{|l|}
\hline \\
\hline \\
\hline \\
\hline \\
\hline \\
\hline
\end{tabular}


Brookhaven National Laboratory

National Toxicology Program

Acrolein Study

Male Rats

Controls

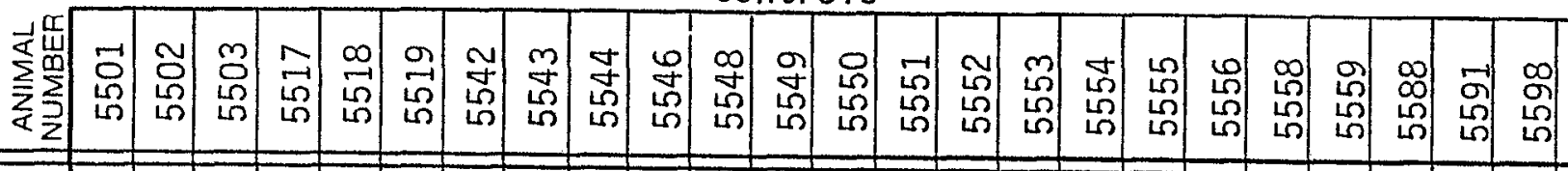

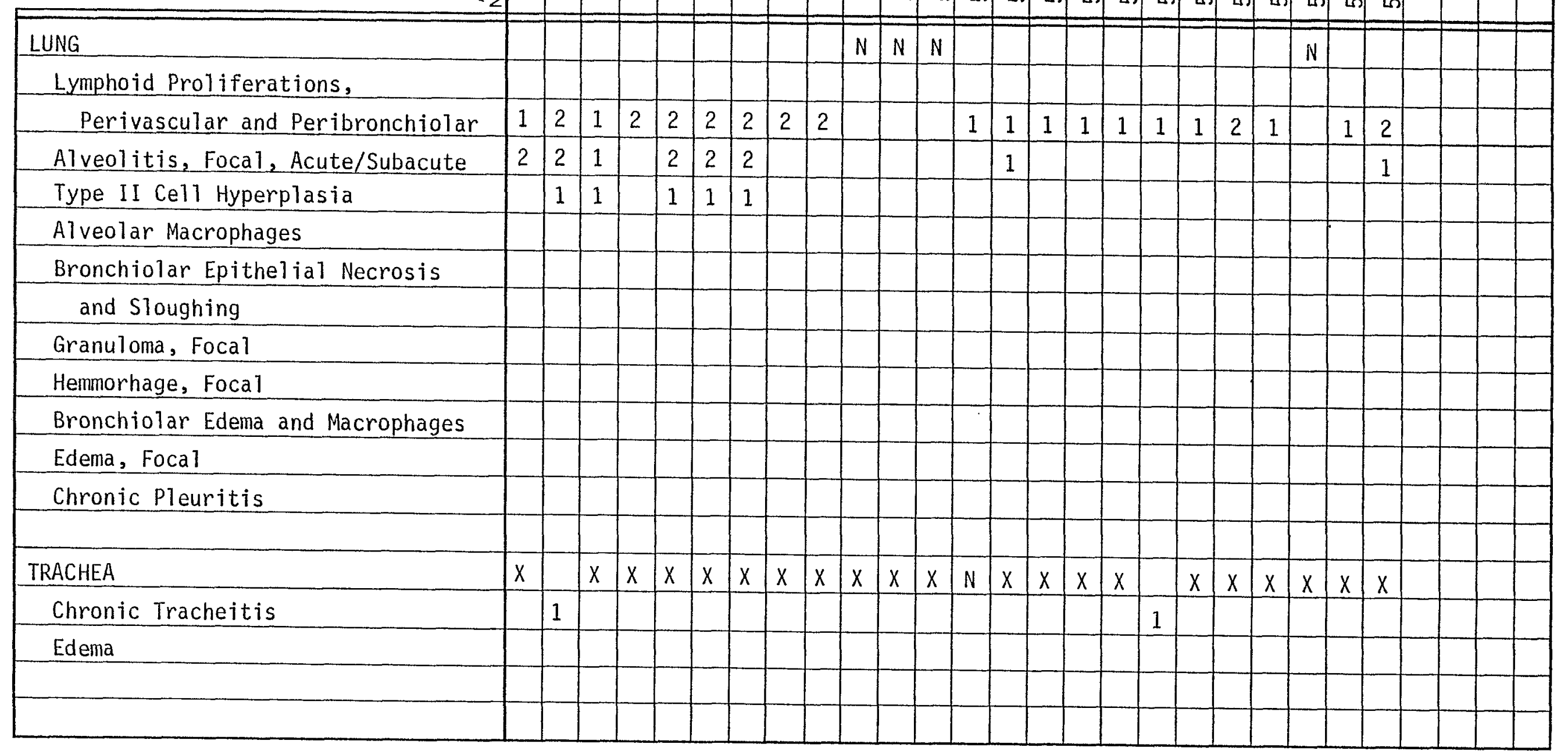

E P L

Experimental Pathology Laboratories, Inc.
Key: $\begin{aligned} P & =\text { Present } \\ 1 & =\text { Minimal }\end{aligned}$

$5=$ Severe/High
$N=$ No Section

$2=$ Slight

$I$ = Incomptele Section
$A=$ Autolysis $\quad \mathrm{X}=$ Not Remarkable

$3=$ Moderate $4=$ Moderalely Severe/High 
Brookhaven National Laboratory

National Toxicology Program

Acrolein Study

Male Rats

Controls

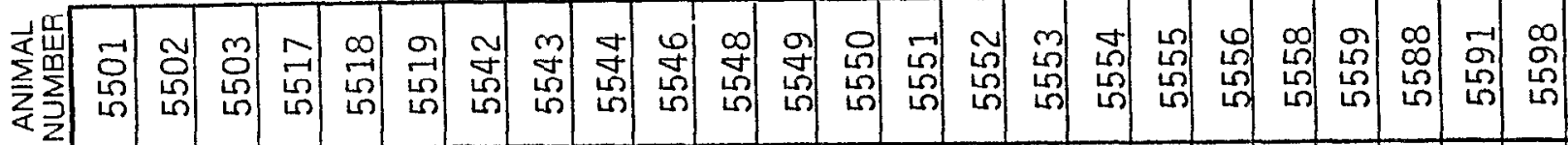

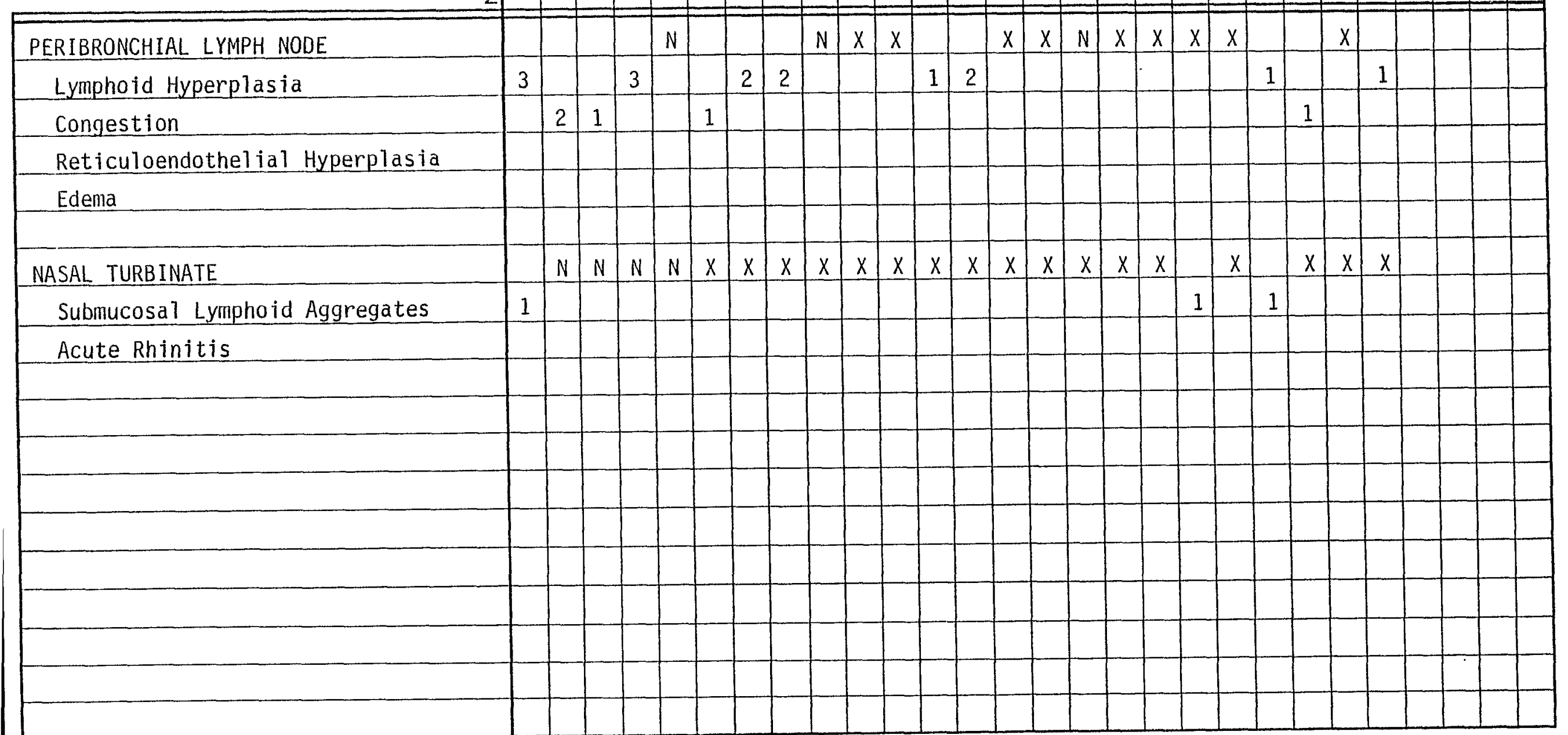

E P L

Experimental Pathology Laboratories, Inc.

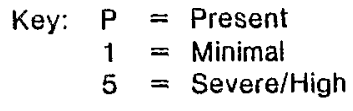

$N=$ No Section

2 = Stight

$A=$ Autolysis $\quad X=$ Not Remarkable

$3=$ Moderate

$4=$ Moderately Severe/High 
Brookhaven National Laboratory

National Toxicology Program

Acrolein Study

Male Rats

Low Dose - $0.4 \mathrm{ppm}$

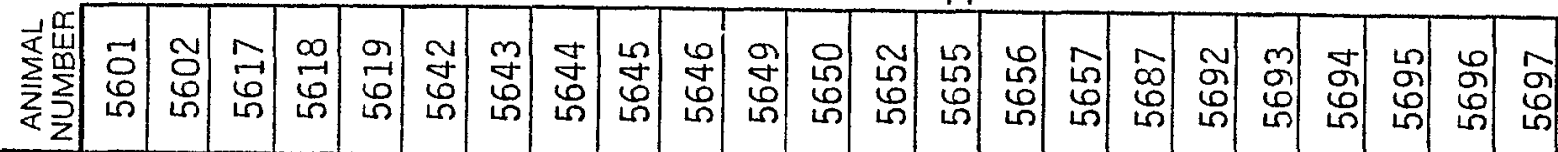

LUNG
Lymphoid Proliferations,

Perivascular and Peribronchiolar Alveolitis, Focal, Acute/Subacute Type II Cell Hyperplasia

Alveolar Macrophages

Bronchiolar Epithelial Necrosis and Sloughing

Granuloma, Focal

Hemmorhage, Foca 7

Bronchiolar Edema and Macrophages

Edema, Focal

Chronic Pleuritis

TRACHEA

Chronic Tracheitis

Edema

\begin{tabular}{|llllllllllllllllllllllllll|l|l|l|}
2 & 1 & 2 & 1 & 1 & 2 & 2 & 2 & 1 & 2 & 2 & 2 & 1 & 1 & 1 & 1 & 1 & 2 & 2 & 1 & 1 & 1 & 2 \\
\hline 3 & & & & & 1 & 1 & & & 1 & & 1 & & & & & & & & & & & 2 \\
2 & & & & & 1 & 1 & & & & & 1 & & & & & & & & & & 1
\end{tabular}

Edema

E P L

Experimental Pathology Laboratories, Inc.
Key: $P=$ Present
$1=$ Minimal
$5=$ Severe/High
$\mathrm{N}=$ No Section
$2=$ Slight
$I$ = Incomplete Section

\begin{abstract}
(1)


Brookhaven National Laboratory

National Toxicology Program

Acrolein Study

Male Rats

Low Dose - $0.4 \mathrm{ppm}$

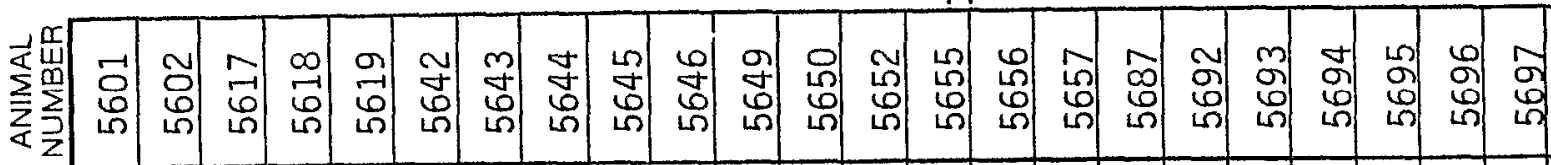

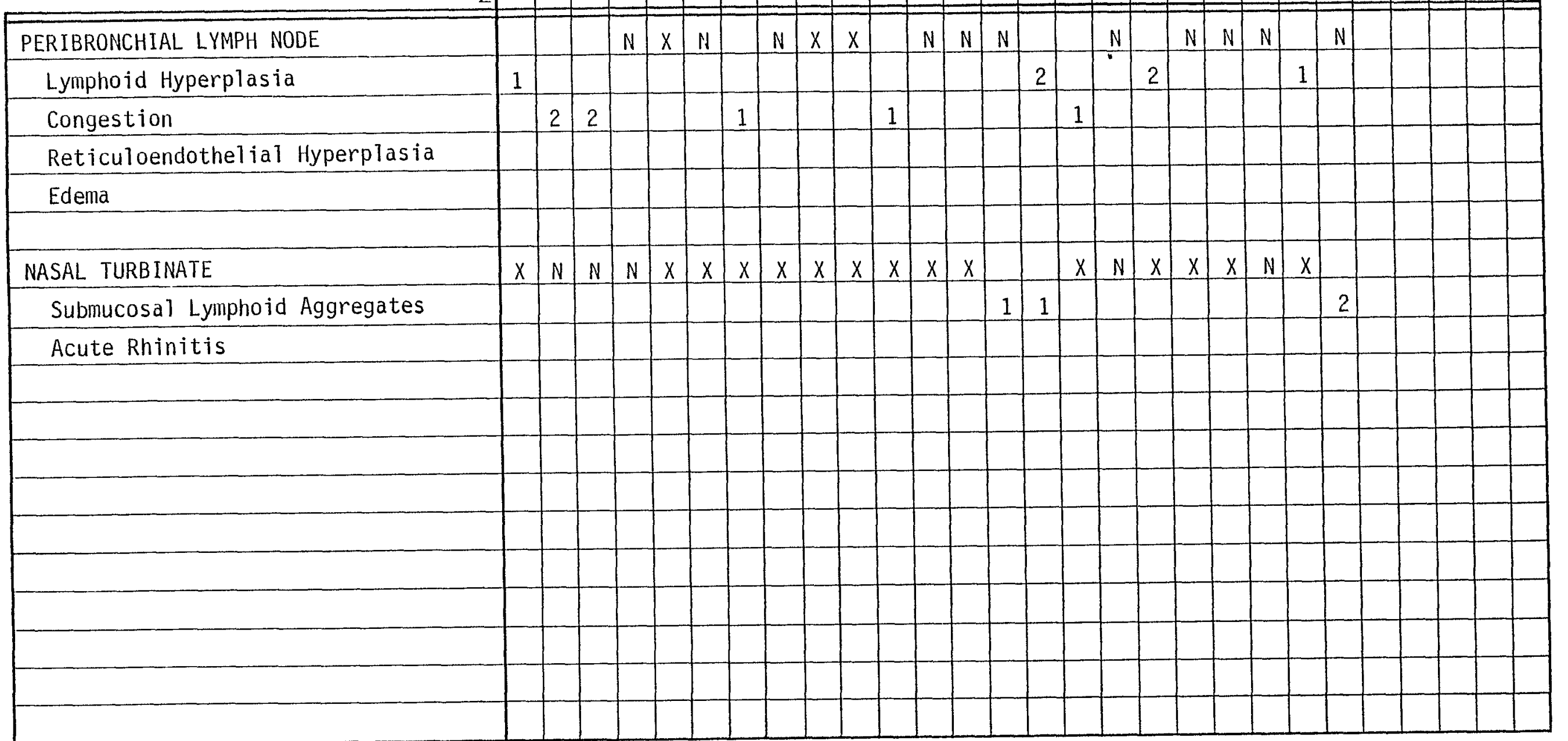

Key: $P \Rightarrow$ Present

Experimental Pathology Laboratories, Inc.
1 = Minimal

$N=$ No Section

$2=$ Slight

$5=$ Severe/High
$A=$ Autolysis

$3=$ Moderate

$x=$ Not Remarkable

$4=$ Moderately Severe/High 
Brookhaven National Laboratory

National Toxicology Program

Acrolein Study

Male Rats

Intermediate Dose $-1.4 \mathrm{ppm}$

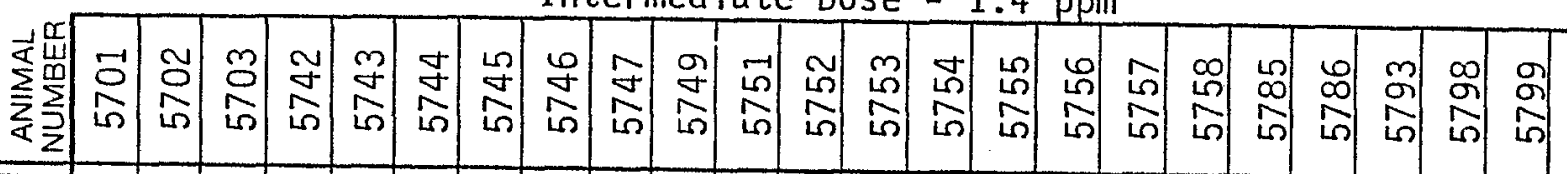

\section{LUNG}

Lymphoid Proliferations,

Perivascular and Peribronchiolar

Alveolitis, Focal, Acute/Subacute

Type II Cell Hyperplasia

Alveolar Macrophages

Bronchiolar Epithelial Necrosis

and Sloughing

Granuloma, Focal

Hemmorhage, Focal

Bronchiolar Edema and Macrophages

Edema, Focal

Chronic Pleuritis

\section{TRACHEA}

Chronic Tracheitis

Edema

\section{$\begin{array}{llllllllllllllllllllllll}x & x & x & x & x & x & x & x & x & x & x & x & x & x & x & x & x & & x & x & x & x & x\end{array}$}

\begin{tabular}{|l|l|l|l|l|l|l|l|l|l|l|l|l|l|l|l|l|l|l|l|l|l|l|}
2 & 2 & 1 & 2 & 2 & 1 & 3 & 2 & 2 & 2 & 2 & 1 & 1 & 2 & 1 & 2 & 1 & 2 & 1 & 2 & 2 & 1 & 2 \\
\hline 2 & 3 & & 2 & 2 & & 3 & 2 & 2 & 1 & & & & & & & & & 1 & 1 & 2 & & 2 \\
\hline 2 & 3 & & 1 & 1 & & 3 & 1 & 1 & & & & & & & & & & & 1 & 1 & & 2 \\
\hline 2 & 2 & & 2 & 2 & & 2 & & 1 & & 1 & & & & 1 & & & 1 & & & 1 & & 1 \\
\hline
\end{tabular}

\begin{tabular}{ll|l|l|l|l|}
2 & & & & & 1
\end{tabular}

1

2 1

E P L

Experimental Pathology Laboratories, Inc.
Key: $\begin{aligned} & P=\text { Present } \\ & 1=\text { Minimal }\end{aligned}$

$5=$ Severe/High
$N=$ No Section

$2=$ Slight

$I=$ Incomplete Section
$A=$ Autolysis $\quad X=$ Not Remarkable

$3=$ Moderate $.4=$ Moderately Severe/High 
Brookhaven National Laboratory National Toxicology Program Acrolein Study Male Rats

Intermediate Dose - $1.4 \mathrm{ppm}$

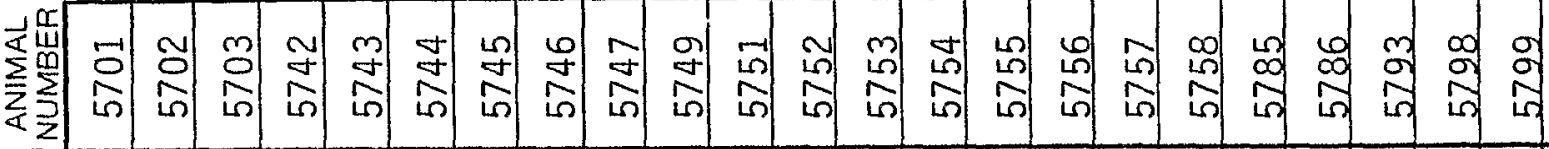

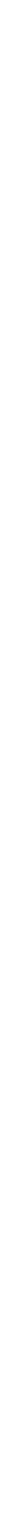


Brookhaven National Laboratory

National Toxicology Program

Acrole in Study

Male Rats

High Dose $-4.0 \mathrm{ppm}$

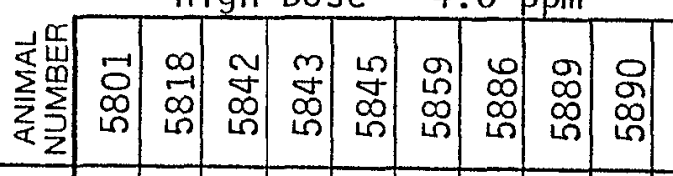

\begin{tabular}{|c|c|c|c|c|c|c|c|c|c|}
\hline LUNG & & & & & & & & & \\
\hline Lymphoid Proliferations, & & & & & & & & & \\
\hline Perivascular and Peribronchiolar & 2 & 1 & 2 & 2 & 2 & 2 & 1 & 2 & 2 \\
\hline Alveolitis, Focal, Acute/Subacute & & & & & & & & 3 & 3 \\
\hline Type II Cell Hyperplasia & & & & & & & & 2 & 3 \\
\hline Alveolar Macrophages & 3 & & & 1 & & & 2 & 2 & 3 \\
\hline Bronchiolar Epithelial Necrosis & & & & & & & & & \\
\hline and Sloughing & 2 & & & 2 & & & & 2 & 2 \\
\hline Granuloma, Focal & & & & & & & & & \\
\hline Hemmorhage, Focal & & & & & & & & & \\
\hline Bronchiolar Edema and Macrophages & 3 & & & 3 & & & 2 & 3 & 1 \\
\hline Edema, Focal & 3 & & & 1 & & 2 & & & \\
\hline Chronic Pleuritis & & & & & & & & 3 & \\
\hline & & & & & & & & & \\
\hline & $x$ & $x$ & $x$ & $X$ & & & & & $\mathrm{x}$ \\
\hline Chronic Tracheitis & & & & & & & & & \\
\hline Edema & & & & & 2 & 2 & 2 & 2 & \\
\hline & & & & & & & & & \\
\hline & & & & & & & & & \\
\hline
\end{tabular}

E P L

Experimental Pathology Laboratories, Inc.
Key: $P=$ Present
$1=$ Minimal
$5=$ Severe/High
$N=$ No Section
$2=$ Slight
$=$ Incomplete Section


High Dose - $4.0 \mathrm{ppm}$

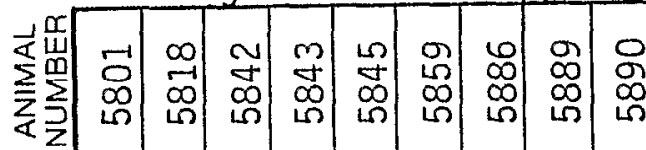

N Lymphoid Hyperplasia Congestion Reticuloendothelial Hyperplasia Edema

NASAL TURBINATE

Submucosal Lymphoid Aggregates Acute Rhinitis

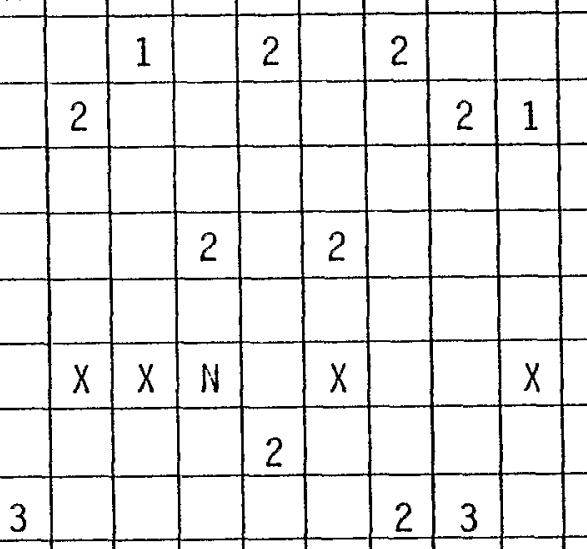

\begin{tabular}{l|l} 
E P 1 & \\
\hline Experimental Pathology Laboratories, lnc.
\end{tabular}

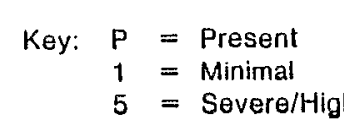

$N=$ No Section

2 = Slight

$A=$ Autolysis
$3=$ Moderate

$A=$ Autolysis
$3=$ Moderate

$x=$ Not Remarkable

$5=$ Severe/High $\quad 1=$ Incomplete Section 
Table 13. Pulmonary Pathology Scores and Overal1 Ordina1 Rank of a11 Fischer 344 Rats which Completed Respiratory Physiology Function Tests after Exposure to Acrolein ${ }^{a}$

\section{0 ppm ACROLEIN}

\begin{tabular}{cc} 
Pulmonary \\
Animal & $\begin{array}{c}\text { Pathology } \\
\text { Score }\end{array}$ \\
\hline
\end{tabular}

Score

$\begin{array}{ll}5501 & 2 \\ 5502 & 3 \\ 5503 & 2\end{array}$

5517

5518

5519

5542

5543

5544

5550

5551

5552

5553

5554

5555

5556

5558

5559

5591

5598
0.4 pPm ACROLEIN

\begin{tabular}{lcc} 
Pulmonary & \\
Numal & $\begin{array}{c}\text { Pathology } \\
\text { Score } \quad \text { Rank }\end{array}$ \\
\hline
\end{tabular}

50.0

57.5

50.0

18.5

57.5

57.5

57.5

18.5

18.5

18.5

41.5

18.5

18.5

18.5

18.5

18.5

18.5

18.5

18.5

41.5
5601

5602

5617

5618

5619

5642

5643

5644

5645

5646

5649

5650

5652

5655

5656

5657

5687

5692

5693

5694

5695

5696

5697
$66.0 \quad 5701$

$18.5 \quad 5702$

$18.5 \quad 5703$

$18.5 \quad 5742$

$18.5 \quad 5743$

$57.5 \quad 5744$

$50.0 \quad 5745$

$18.5 \quad 5746$

$18.5 \quad 5747$

$41.5 \quad 5749$

$41.5 \quad 5751$

$50.0 \quad 5752$

$18.5 \quad 5753$

$18.5 \quad 5754$

$18.5 \quad 5755$

$18.5 \quad 5756$

$18.5 \quad 5757$

$18.5 \quad 5758$

$41.5 \quad 5785$

$18.5 \quad 5786$

$18.5 \quad 5793$

$18.5 \quad 5798$

57.5

5799
$1.4 \mathrm{ppm}$ ACROLEIN

Pulmonary Pathology Score

\section{$4.0 \mathrm{ppm}$ ACROLEIN}

Pulmonary Animal Pathology

Number Score Rank

$\begin{array}{lll}5801 & 11 & 73.0\end{array}$

5818

5842

5843 .

5845

5859

5886

5889

5890

66.0

41.5

41.5

18.5

18.5

50.0

41.5

18.5

18.5

41.5

41.5

57.5

62.5

18.5

66.0

$\begin{array}{ll}15 & 75.0 \\ 12 & 74.0\end{array}$

Mean Value 0.9

31.8

0.8

29.7

2.7

46.6

5.7

51.1

${ }^{a}$ Six hours/day, five days/week, 62 days. 


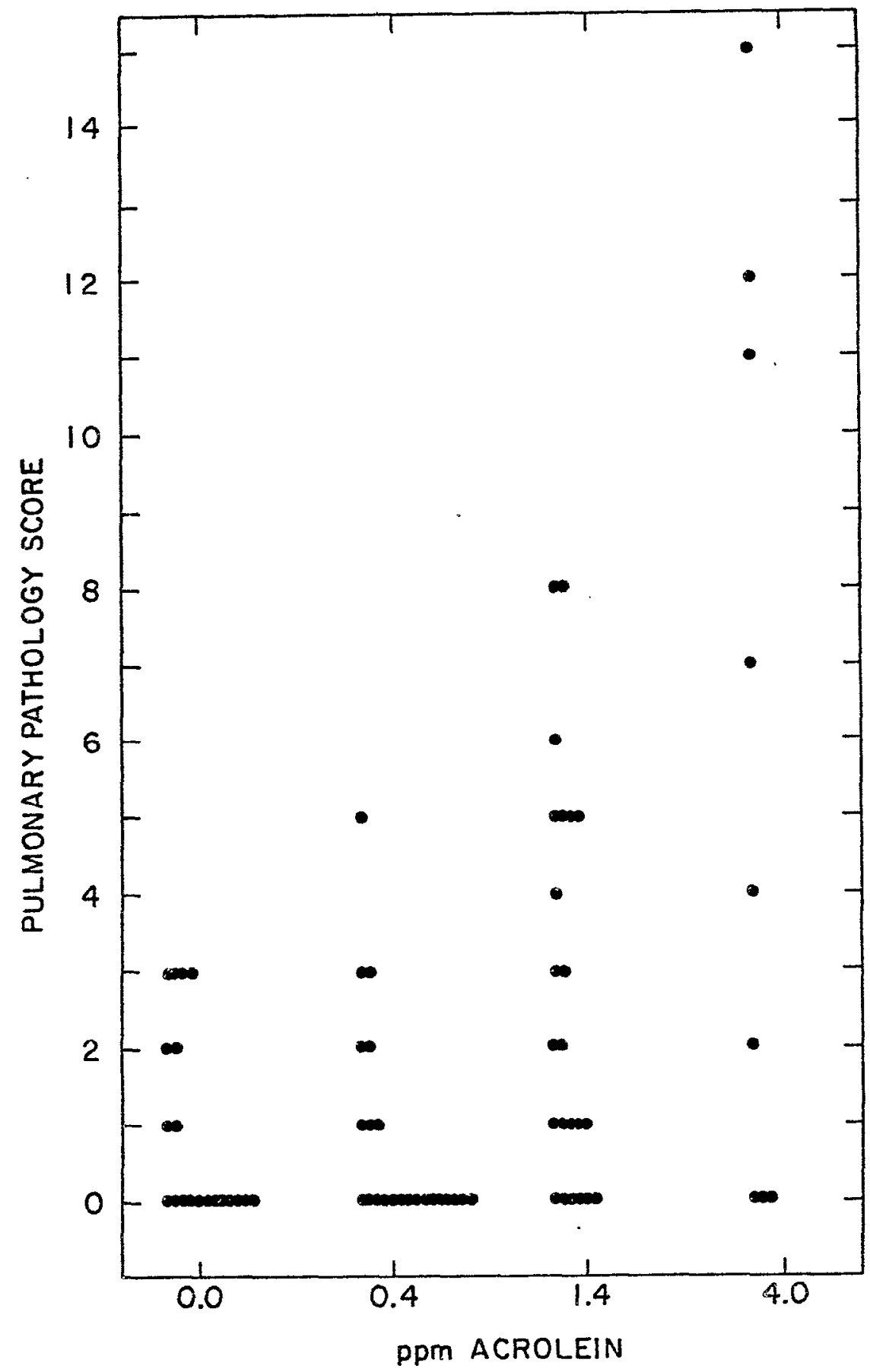

Figure 15: Frequency of pulmonary pathology scores of Fischer 344 rats exposed to acrolein for 62 days ( 6 hours/day, 5 days/week). (See text for details.) 
Lung Composition Data

The right lungs of animals which completed pulmonary function tests were assayed for protein, DNA, elastin, and hydroxyproline (an index of collagen) concentration as well as water content. The mean animal weight of each exposure group has been provided in Table 14. The data for individual animals has been provided in Appendix $F$. The relationship of these data to the pathology and the pulmonary function data of all exposure groups was also statistically evaluated (see Statistical Relationships Among Data).

Lung Weight and Water Content. Although the body weights of the rats exposed to $4.0 \mathrm{ppm}$ acrolein were markedly reduced, the lungs of these animals were significantly heavier than those of any other exposure group (Table 14). This increased lung weight was due to a $20 \%$ increase in dry weight mass accompanied by a $1.5 \%$ increase in water content per unit dry weight (Table 14).

Lung DNA. The total lung DNA content of the $4.0 \mathrm{ppm}$ animals was significantly greater than that of the other exposure groups (Table 15). However, if expressed on a per gram wet weight basis, the DNA concentration of this group was less than that of the control or $0.4 \mathrm{ppm}$ exposure groups. The marked increase in lung dry weight in the $4.0 \mathrm{ppm}$ group (Table 14) and the absence of a significant difference in the amount of DNA per unit dry weight (Table 15) were indications that the increased Iung weight of the high dose group was in part due to increased cellularity.

Lung Protein. The concentration of lung protein followed a pattern very similar to that observed for pulmonary DNA in all exposure groups. The uniform concentration of protein per milligram dry weight and per 
milligram DNA (Table 16) again indicated increased lung tissue in the 4.0 ppm exposed animals.

Lung Elastin. The total lung elastin content of rats exposed to 4.0 ppm acrolein was twice that of the control and lower exposure groups (Table 17). This marked increase was also evident when the elastin concentration was based on DNA, protein, or dry weight (Table 17). However, such an increase in elastin content would have little effect on total lung weight because elastin accounts for less than $1 \%$ of 1 ung wet weight.

Lung Collagen. Hydroxyproline was used as an index of lung collagen content. Of the lung constituents assessed, only collagen content changed significantly from control values in the animals exposed to 1.4 ppm acrolein. Lung hydroxyproline content was increased by exposure to 1.4 ppm as well as $4.0 \mathrm{ppm}$ acrolein (Table 18). The total lung hydroxyproline content of the 4.0 ppu group was significantly greater than that of all other exposure groups while the 1.4 ppm group had significantly more hydroxyproline than the control and low dose animals but significantly less than the high dose group. When based on wet weight, the pulmonary hydroxyproline concentration of the 1.4 and $4.0 \mathrm{ppm}$ groups did not differ, and both were significantly greater than the control concentration (Table 18). When based on either dry weight or protein content, the hydroxyproline concentration of the $4.0 \mathrm{ppm}$ lungs was greater than that of all other exposure groups, and the hydroxyproline concentration of the 1.4 ppm lungs was markedly increased when compared to that of the controls and $0.4 \mathrm{ppm}$ exposed lungs (Table 18). Although these changes were rather marked, increased collagen content contributes little to total lung weight because of the small amount present. 
Table 14. Body Weight and Lung Weight Data from Fischer 344 Rats Exposed to Filtered Air or Acrolein ${ }^{a}$




Table 15. Lung DNA Data from Fischer 344 Rats Exposed to Filtered Air or Acrolein

\begin{tabular}{|c|c|c|c|}
\hline 0.0 & 0.4 & 1.4 & 4.0 \\
\hline$n=24$ & $\mathrm{n}=23$ & $\mathrm{n}=22$ & $\mathrm{n}=8$ \\
\hline
\end{tabular}

Total Lung

DNA (mg)

$$
6.24(.114)^{b} \quad 6.21(.141)
$$

$6.22(.121)$

$7.28(.136)^{c}$

mg DNA/gm Wet Wt.

$4.83(.049)$

$4.85(.055)$

$4.65(.083)$

$4.32(.104)^{d}$

mg DNA/mg Dry Wt.

$0.023(.000) \quad 0.024(.000)$

$0.023(.000) \quad 0.023(.000)$

mg DNA/mg Protein

$0.042(.000) \quad 0.043(.000)$

$0.041(.001)$

$0.041(.001)$

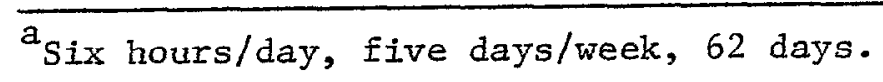

$b_{\text {Mean (ts.e.). }}$

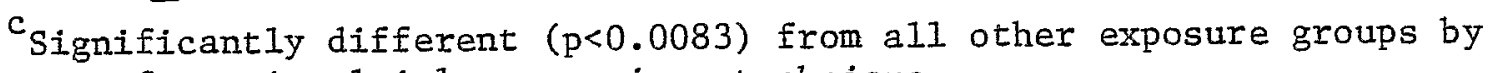
Bonferroni multiple comparison technique.

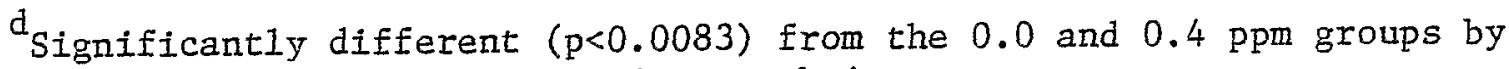
Bonferroni multiple comparison technique. 
Table 16. Lung Protein Data from Fischer 344 Rats Exposed to Filtered Air or Acrolein ${ }^{a}$

\footnotetext{
ACROLEIN EXPOSURE CONCENTRATION (pPm)

$\begin{array}{llll}0.0 & 0.4 & 1.4 & 4.0 \\ n=24 & n=22 & n=8\end{array}$

Total Lung Protein

(mg)

$147.5(2.97)^{\mathrm{b}} \quad 146.5(3.82) \quad 154.5(4.71) \quad 177.7(5.25)^{\mathrm{c}}$

mg Protein/gm Wet Wt. 114.1(.75) $114.2(1.37) \quad 114.7(1.65) \quad 105.3(2.53)^{c}$

mg Protein/mg Dry Wt. $\quad 0.55(.005) \quad 0.56(.009) \quad 0.56(.006) \quad 0.55(.008)$

$\begin{array}{lllll}\text { mg Protein/mg DNA } 23.7(0.23) & 23.6(.23) & 24.8(.52) & 24.4(.54)\end{array}$

$\mathrm{a}_{\text {Six }}$ hours/day, five days/week, 62 days.

Mean (ts.e.).

${ }^{c}$ Significantly different $(p<0.0083)$ from all other exposure groups by Bonferroni multiple comparison technique.
} 
Table 17. Lung Elastin Data from Fischer 344 Rats Exposed to Filtered Air or Acrolein

\begin{tabular}{|c|c|c|c|c|}
\hline & \multicolumn{2}{|c|}{ ACROLEIN EXPOSURE } & \multicolumn{2}{|c|}{ CONCENTRATION (ppm) } \\
\hline & 0.0 & 0.4 & 1.4 & 4.0 \\
\hline & $n=24$ & $\mathrm{n}=23$ & $n=22$ & $n=8$ \\
\hline $\begin{array}{l}\text { Total Lung Elastin } \\
\text { (mg) }\end{array}$ & $5.91(.126)^{b}$ & $6.10(.136)$ & $6.43(.169)$ & $12.53(1.028)^{c}$ \\
\hline mg Elastin/gm Wet Wt. & $4.60(.125)$ & $4.80(.129)$ & $4.84(.173)$ & $7.39(.558)^{\mathrm{c}}$ \\
\hline mg Elastin/mg Dry wt. & $0.02(.001)$ & $0.02(.001)$ & $0.02(0.001)$ & $0.04(.003)^{\mathrm{c}}$ \\
\hline mg Elastin/mg DNA & $0.95(.025)$ & $0.99(.024)$ & $1.04(.030)$ & $1.71(.124)^{c}$ \\
\hline mg Elastin/mg Protein & $0.04(.001)$ & $0.04(.001)$ & $0.04(.001)$ & $0.07(.006)^{c}$ \\
\hline
\end{tabular}


Table 18. Lung Hydroxyproline Data from Fischer 344 Rats Exposed to Filtered Air and Acrolein ${ }^{a}$

\footnotetext{
ACROLEIN EXPOSURE CONCENTRATION (pDm)

$\begin{array}{llll}0.0 & \frac{0.4}{n=23} \quad \frac{1.4}{n=22} & 4.0 \\ n=8 & \end{array}$

Total Lung

$\begin{array}{lllll}\text { Hydroxyproline (mg) } & 2.38(.043)^{\mathrm{b}} & 2.53(.052) & 2.82(.054)^{\mathrm{c}} & 3.99(.147)^{\mathrm{c}}\end{array}$

mg OH-PRO/gm Wet Wt. $\quad 1.85(.032) \quad 1.99(.053) \quad 2.11(.058)^{\mathrm{d}} \quad 2.36(.077)^{\mathrm{e}}$

$\mathrm{mg}$ OH-PRO/mg Dry Wt. $\quad 0.009(.000) \quad 0.010(.000) \quad 0.010(.000)^{\mathrm{f}} \quad 0.012(.000)^{\mathrm{c}}$

ing OH-PRO/mg DNA $\quad 0.38(.007) \quad 0.41(.010) \quad 0.45(.010)^{\mathrm{C}} \quad 0.55(.017)^{\mathrm{C}}$

mg OH-PRO/mg Protein $\quad 0.016(.000) \quad 0.017(.000) \quad 0.018(.000)^{\mathrm{d}} 0.023(.001)^{\mathrm{c}}$

${ }^{a}$ Six hours/day, five days/week, 62 days.

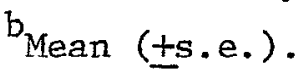

CSignificantly different $(p<0.0083)$ from all other exposure groups by Bonferroni multiple comparison technique.

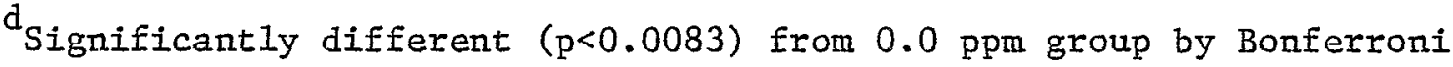
multiple comparison technique.

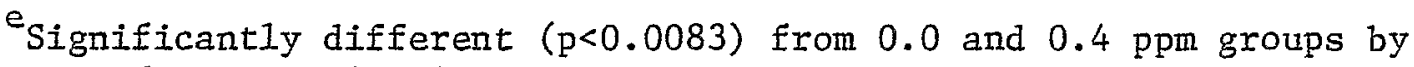
Bonferroni multiple comparison technique.

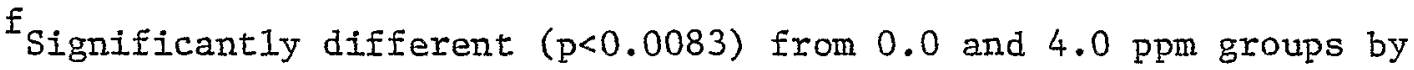
Bonferroni multiple comparison technique.
} 
Cytology Results

Bone Marrow. The results of the sister chromatid exchange (SCE) and cellular proliferation studies in populations of bone marrow cells from control, $0.4,1.4$, and $4.0 \mathrm{ppm}$ acrolein-exposed rats have been provided in Table'19. The SCE data were normalized by square root transformation and were then compared using the Student's t test. No significant differences were observed between any of the exposure groups and the controls. No significant changes were observed between the control and exposed animals in the relative proportions of first-, second-, and third-generation metaphase cells (cell proliferation kinetics, Table 19). Analysis of chromosomal aberrations was not possible, because few first-generation metaphase cells were observed in the bone marrow of rats sacrificed after 25 hours of Brdurd infusion.

Peripheral Blood Lymphocytes. The analysis of the SCE and chromosomal aberration data from peripheral blood lymphocytes of control rats and those exposed to acrolein have been provided in Tables 20 and 21 . Using a square root transformation to analyze the SCE data for statistical differences (Student's t-test), no significant differences were observed between the control cell populations and those of any exposure group (Table 20). Analysis of the relative proportions of first-, second-, and third-generation metaphase cells indicated that there were no differences in the cell proliferation kinetics among these groups (Table 20). Because the number of first-generation metaphase cells was limited, scoring of chromosomal aberrations was restricted to 50 cells (first-generation) per animal. On the basis of these data, there were no statistically significant differences (student's t-test) in the frequency of chromosomal aberrations or in the percent abnormal cells between the control rats and rats exposed to either 1.4 or $4.0 \mathrm{ppm}$ acrolein (Table 21). Slides from the $0.4 \mathrm{ppm}$ exposed animals 
were not scored because the higher exposure concentrations did not demonstrate an effect.

Lung Alveolar Macrophages. The studies on alveolar macrophages from lung washes were severely limited by both a very low mitotic index and the presence of only first-generation cells in all exposure groups. Consequently, it was not possible to score for SCEs or to score chromosomal aberrations.

Sperm Morphology. Sperm samples from at least nine rats in each exposure group were examined for abnormal cells. The data from individual animals are available in Appendix $G$. There were no significant differences among groups when the data were analyzed by either the Kruskal1-Wallis nonparametric test or by one way ANOVA after arcsin transformation of the data. 
Table 19. Frequency of Sister Chromatid Exchange and Relative Rates of Cell Proliferation in Bone Marrow Cells of Fischer 344 Rats Exposed to Acrolein ${ }^{2}$

\begin{tabular}{|c|c|c|c|c|c|c|}
\hline \multirow{2}{*}{$\begin{array}{c}\text { Acrolein } \\
\text { Concentration } \\
\text { (ppm) } \\
\end{array}$} & \multirow{2}{*}{$\begin{array}{l}\text { Animal } \\
\text { Number }\end{array}$} & \multicolumn{2}{|c|}{$\mathrm{SCE} / \mathrm{Ce} 11^{\mathrm{b}}$} & \multicolumn{3}{|c|}{ Ce11 Proliferation Kinetics $(\%)^{c}$} \\
\hline & & Raw Data & $\sqrt{x}$ Transformed Data & $\underline{I}$ & II & $\underline{I I I}$ \\
\hline \multirow[t]{6}{*}{0.0} & 5504 & $5.52(0.32)$ & $2.31(0.08)$ & 23 & 70 & 7 \\
\hline & 5506 & $4.89(0.59)$ & $2.48(0.12)$ & 34 & 64 & 2 \\
\hline & 5508 & $5.12(0.41)$ & $2.22(0.09)$ & 27 & 72 & 1 \\
\hline & 5520 & $5.56(0.37$ & $2.32(0.08)$ & .. 1 & 66 & 33 \\
\hline & 5584 & $5.00(0.36)$ & $2.20(0.08)$ & 12 & 77 & 11 \\
\hline & $\sum^{\mathrm{d}}$ & $5.22(0.15)$ & $2.31(0.06)$ & $19,4(6,54)$ & $69.8(2.56)$ & $10.8(6.52)$ \\
\hline \multirow[t]{6}{*}{0.4} & 5604 & $5.48(0.39)$ & $2.30(0.09)$ & 8 & 91 & 1 \\
\hline & 5605 & $5.56(0.37)$ & $2.33(0.08)$ & 22 & 76 & 2 \\
\hline & 5606 & $5.60(0.34)$ & $2.34(0.07)$ & 14 & 84 & 2 \\
\hline & 5607 & $4.60(0.36)$ & $2.10(0.09)$ & 24 & 76 & 0 \\
\hline & 5608 & $5.56(0.44)$ & $2.31(0.10)$ & 16 & 83 & 1 \\
\hline & $\sum$ & $5.36(0.21)$ & $2.28(0.05)$ & $16.8(3.21)$ & $82.0(3.14)$ & $1.2(0.42)$ \\
\hline \multirow[t]{6}{*}{1.4} & 5704 & $5.32(0.52)$ & $2.23(0.18)$ & 10 & 87 & 3 \\
\hline & 5705 & $5.40(0.46)$ & $2.27(0.10)$ & 12 & 84 & 4 \\
\hline & 5706 & $5.44(0.56)$ & $2.27(0.11)$ & 65 & 35 & 0 \\
\hline & 5707 & $5.40(0.51)$ & $2.26(0.11)$ & 15 & 83 & 2 \\
\hline & 5708 & $5.20(0.48)$ & $2.22(0.11)$ & 21 & 69 & 10 \\
\hline & $\sum$ & $5.35(0.05)$ & $2.25(0.01)$ & $24.6(11.48)$ & $71.6(10.80)$ & $3.8(1.88)$ \\
\hline
\end{tabular}


Table 19 -- Continued

\begin{tabular}{|c|c|c|c|c|c|c|}
\hline \multirow{2}{*}{$\begin{array}{c}\text { Acrolein } \\
\text { Concentration } \\
\text { (ppm) }\end{array}$} & \multirow{2}{*}{$\begin{array}{l}\text { Anima1 } \\
\text { Number } \\
\end{array}$} & \multicolumn{2}{|c|}{$\mathrm{SCE} / \mathrm{Ce} 11^{\mathrm{b}}$} & \multicolumn{3}{|c|}{ Ce11 Proliferation Kinetics $(\%)^{c}$} \\
\hline & & Raw Data & $\sqrt{x}$ Transformed Data & $\underline{I}$ & II & III \\
\hline \multirow[t]{6}{*}{4.0} & 5805 & $5.12(0.38)$ & $2.22(0.09)$ & 19 & 71 & 10 \\
\hline & 5806 & $4.16(0.24)$ & $2.02(0.06)$ & 13 & 80 & 7 \\
\hline & 5808 & $5.12(0.51)$ & $2.20(0.11)$ & 32 & 67 & 1 \\
\hline & 5884 & $5.88(0.44)$ & $2.37(0.10)$ & 26 & 73 & 1 \\
\hline & 5820 & $4.64(0.32)$ & $2.12(0.07)$ & 2 & 79 & 19 \\
\hline & $\sum^{d}$ & $4.98(0.32)$ & $2.19(0.06)$ & $18.4(5.82)$ & $74.0(2.74)$ & 7.6 \\
\hline
\end{tabular}

\footnotetext{
${ }^{a}$ Six hours/day, five days/week, 62 days.

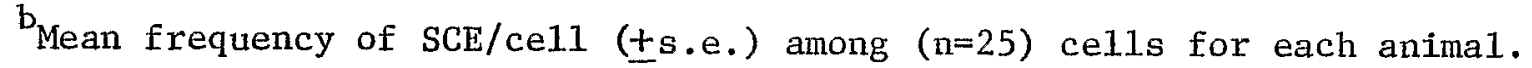

${ }^{c}$ Percent of cells which had replicated for one (I), two (II), or three (III) generations in a sample of 100 randomly chosen metaphase cells.

${ }^{d}$ Mean of mean frequency of SCE/cell ( $t$ s.e.) among $n$ animals and mean percent of metaphase cells in each generation (ts.e.) among $n$ animals.
} 
Table 20. Frequency of Sister Chromatid Exchange and Relative Rates of Ce11-Proliferation in PHA-Stimulated Periphera1 Blood Lymphocytes of Fischer 344 Rats Exposed to Acrolein

\begin{tabular}{|c|c|c|c|c|c|c|}
\hline \multirow{2}{*}{$\begin{array}{l}\text { Acrolein } \\
\text { Concentration } \\
(\mathrm{ppm})\end{array}$} & \multirow{2}{*}{$\begin{array}{l}\text { Animal } \\
\text { Number }\end{array}$} & \multicolumn{2}{|c|}{$\mathrm{SCE} / \mathrm{Ce} 11^{\mathrm{b}}$} & \multicolumn{3}{|c|}{ Cell Proliferation Kinetics $(\%)^{c}$} \\
\hline & & Raw Data & $\sqrt{\text { Root Transformed }}$ & $\underline{I}$ & $\underline{I I}$ & III \\
\hline \multirow[t]{5}{*}{0.0} & 5504 & $8.52(0.52)$ & $2.87(0.11)$ & 39 & 30 & 31 \\
\hline & 5505 & $8.31(0.44)$ & $2.81(0.09)$ & 46 & 44 & 10 \\
\hline & 5508 & $7.73(0.46)$ & $2.77(0.08)$ & 51 & 35 & 14 \\
\hline & 5521 & $7.32(0.39)$ & $2.68(0.09)$ & 41 & 53 & 6 \\
\hline & $\Sigma^{\mathrm{d}}$ & $7.97(0.32)$ & $2.78(0.05)$ & $44.25(3.10)$ & $40.5(5.86)$ & $15.25(6.35)$ \\
\hline \multirow[t]{5}{*}{0.4} & 5604 & $8.20(0.75)$ & $2.82(0.10)$ & 41 & 32 & 27 \\
\hline & 5646 & $6.64(0.46)$ & $2.49(0.09)$ & 44 & 37 & 19 \\
\hline & 5606 & $7.76(0.57)$ & $2.74(0.10)$ & 45 & 38 & 17 \\
\hline & 5607 & $8.84(0.56)$ & $2.94(0.10)$ & 50 & 45 & 5 \\
\hline & $\sum$ & $7.86(0.53)$ & $2.75(0.11)$ & $45.0(2.16)$ & $38.0(3.09)$ & $17.0(5.25)$ \\
\hline \multirow[t]{5}{*}{1.4} & 5707 & $8.00(0.64)$ & $2.78(0.10)$ & 46 & 28 & 26 \\
\hline & 5708 & $8.08(0.67)$ & $2.79(0.11)$ & 43 & 40 & 17 \\
\hline & 5746 & $6.80(0.47)$ & $2.57(0.08)$ & 42 & 34 & 24 \\
\hline & 5704 & $8.56(0.48)$ & $2.90(0.08)$ & 44 & 50 & 6 \\
\hline & $\sum$ & $7.86(0.43)$ & $2.76(0.08)$ & $43.8(0.99)$ & $38.0(5.42)$ & $18.2(5.21)$ \\
\hline
\end{tabular}




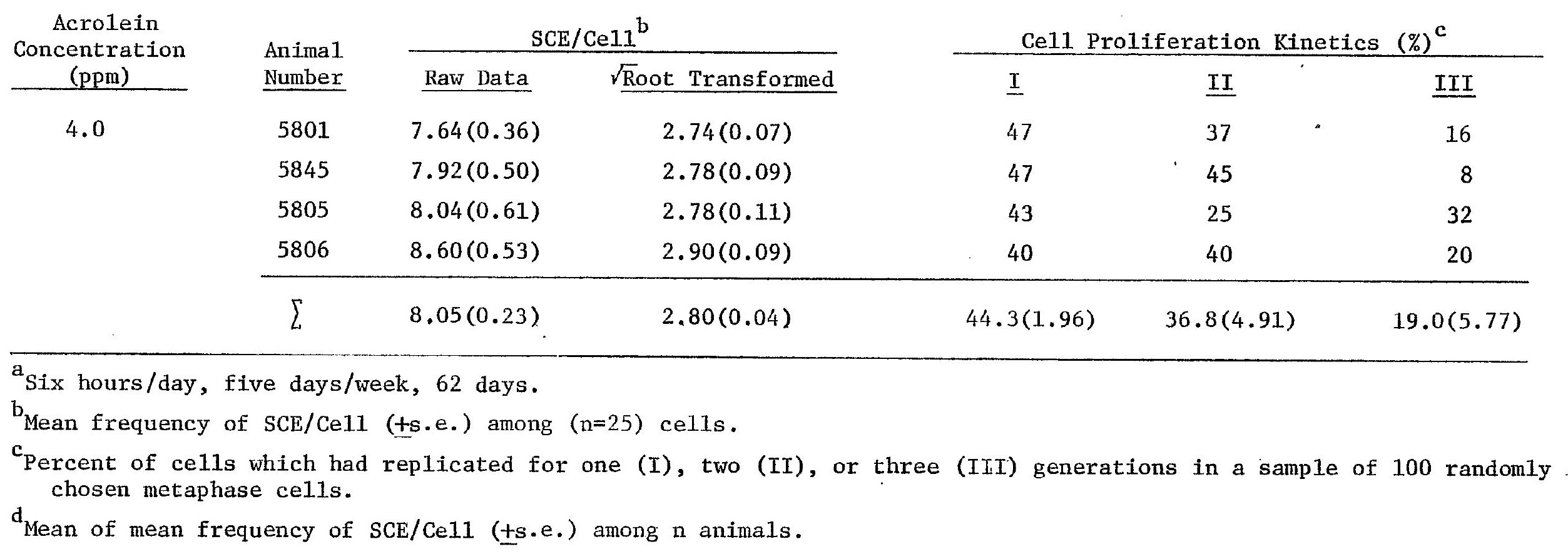


Table 21. Chromosoma1 Aberration Frequencies in PHA-Stimulated Periphera1 Blood Lymphocytes of Fischer-344 Rats Exposed to Acrolein ${ }^{a}$

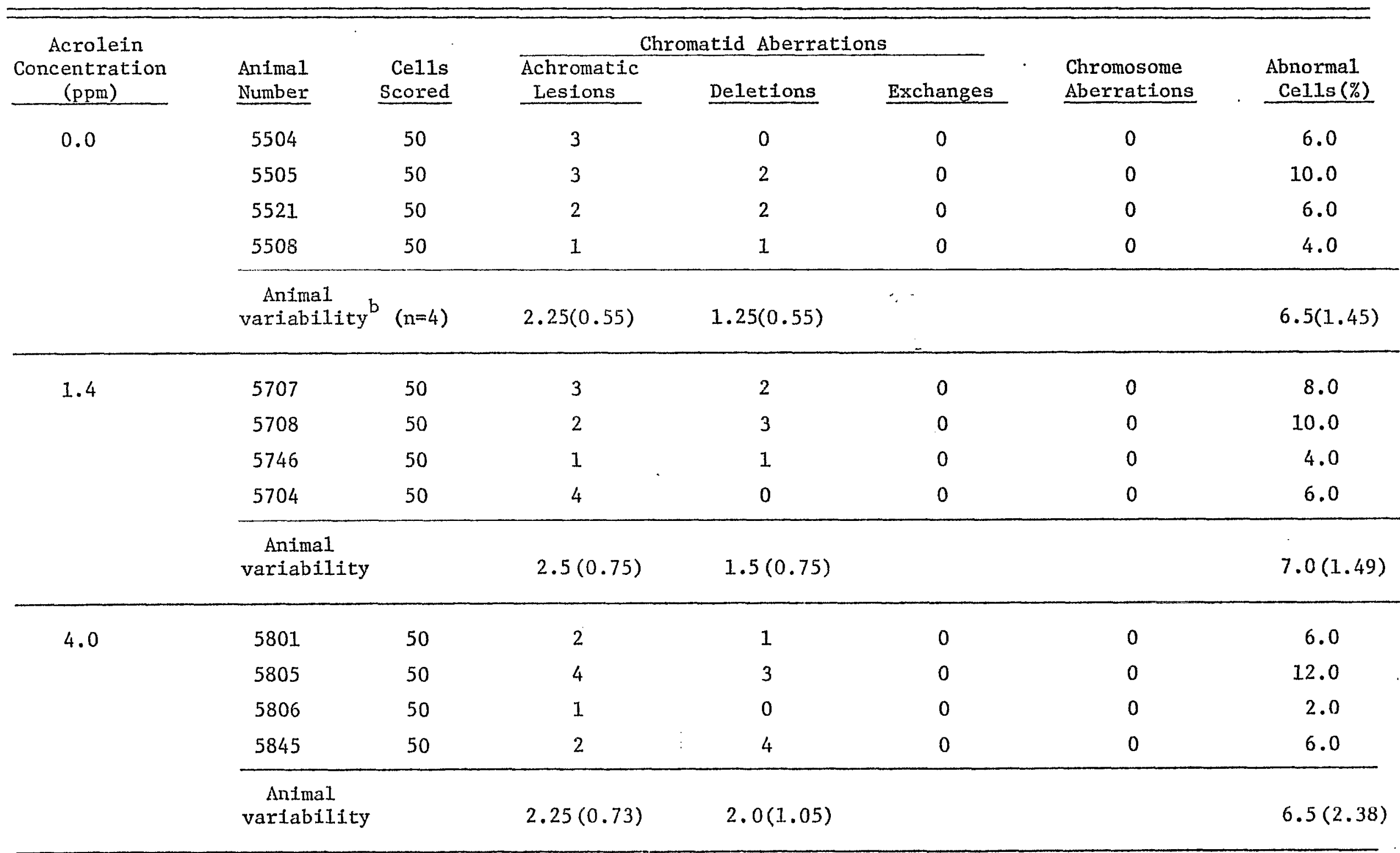

${ }^{\text {a }}$ Six hours/day, five days/week, 62 days.

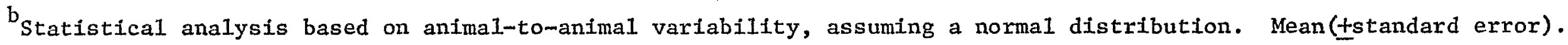


Reproductive Potential Studies

The reproductive fitness data resulting from the mating of acrolein exposed and control male rats to unexposed females has been provided in Table 22. No significant differences (Student's t-test) were observed between females mated with control males and females mated with males from any of the acrolein exposure groups. The reproductive potential of female rats appeared unaffected by exposure to acrolein (Table 23). 
Table 22 Reproductive Fitness of Male Fischer 344 Rats After Exposure to 0.4 , 1.4, or $4.0 \mathrm{ppm}$ Acrolein ${ }^{\mathrm{a}}$. Each Male Was Caged with Two Unexposed Female Rats Beginning Six Days After the Final Exposure.

\begin{tabular}{|c|c|c|c|c|}
\hline & \multicolumn{4}{|c|}{ Acrolein Exposure Concentration (ppm) } \\
\hline & 0.0 & 0.4 & 1.4 & 4.0 \\
\hline $\begin{array}{c}\text { Pregnant Females/ } \\
\text { Number Mated }\end{array}$ & $7 / 16$ & $6 / 16$ & $8 / 14$ & $5 / 10$ \\
\hline Corpora Iutea & $10.1(1.16)^{b}$ & $10.8(0.48)$ & $11.6(0.65)$ & $10.8(1.11)$ \\
\hline Viable Embryos & $9.0(1.07)$ & $10.2(0.65)$ & $9.0(0.89)$ & $9.0(1.05)$ \\
\hline Early Deaths & $0.1(0.14)$ & 0.0 & $0.4(0.18)$ & 0.0 \\
\hline Late Deaths & 0.0 & 0.0 & 0.0 & 0.0 \\
\hline Preimplantation Losses & $1.0(0.58)$ & $0.7(0.33)$ & $2.2(0.53)$ & $1.8(0.38)$ \\
\hline
\end{tabular}


93

Table 23. Reproductive Fitness of Female Fischer 344 Rats After Exposure to $0.4,1.4$, and $4.0 \mathrm{ppm}$ Acrolein ${ }^{\mathrm{a}}$. Each Female was Mated with a Single Proven Male Beginning Six Days After the Final Exposure

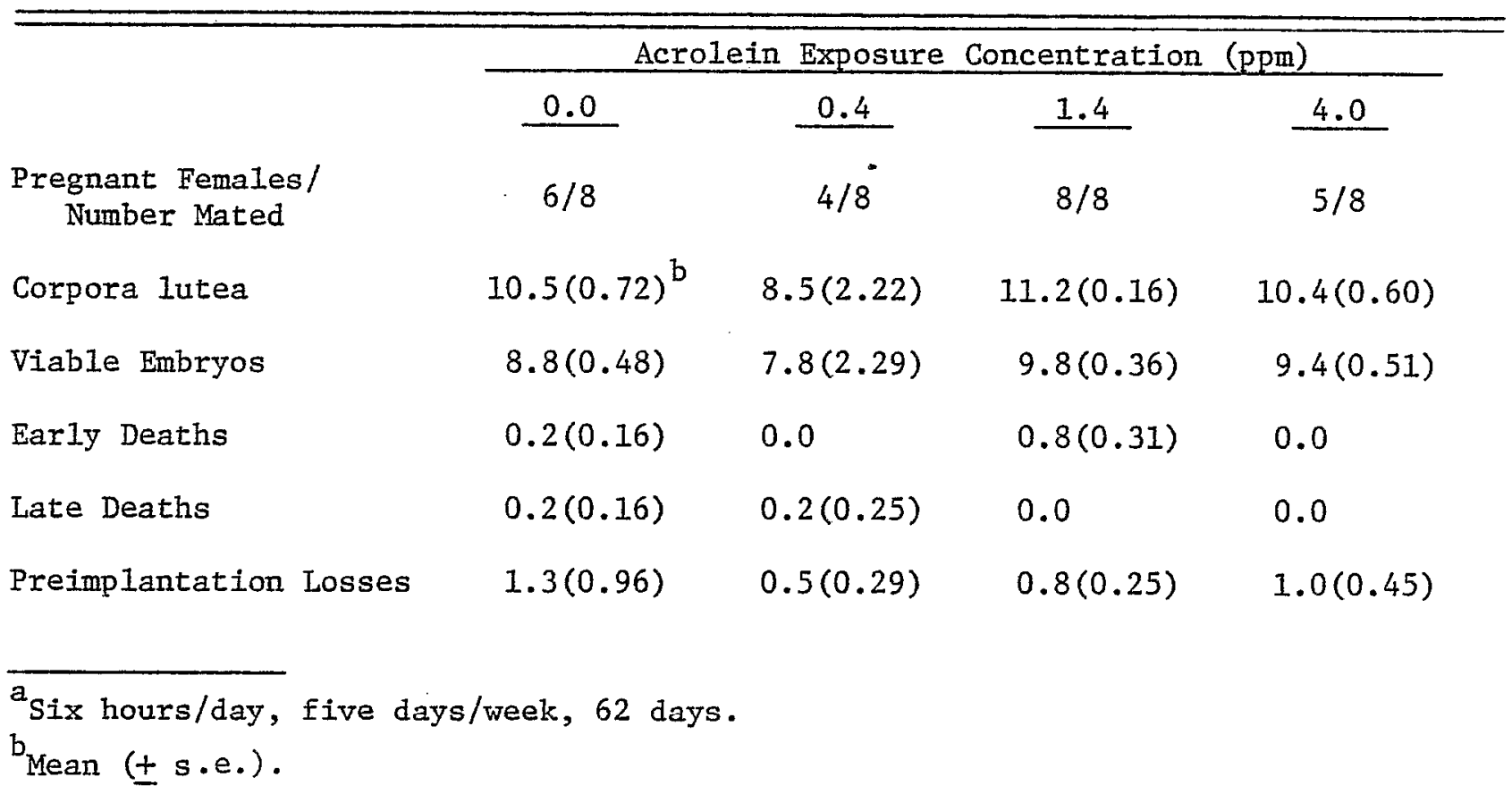


Statistical Relationships Among Data

Correlation Analysis. Twenty-six variables from each animal were available for correlation analysis after pulmonary function testing, assessment of lung connective tissue, and histopathologic examination of rats in each designated subgroup. The variables utilized in these analyses are listed in Table 24. Many of the respiratory physiology parameters have been expressed as a function of either $F R C_{d}$, TLC $d$, or $V C$, on which they were dependent. All of the lung composition data were normalized to dry weight. Only those sets of correlation coefficients where at least one exposure group demonstrated a significant linear association between the parameters considered have been provided in Table 25.

Several significant associations were found to exist between functional and compositional variables in the control group. Elastin concentration was associated with $F R_{b}$, hydroxyproline content with $f$, lung weight with $\dot{\mathrm{V}}_{E}$, and protein with PEF, EFR 50 , and $\dot{\mathrm{V}}_{E}$. While large normal lungs have greater volumes and probably greater maximum flows than sma11 normal lungs there is no reason to speculate that these relationships would be maintained after pulmonary insult. In fact, the above associations were not evident in any of the acrolein exposure groups. The control pathology ranking, which probably reflected occasional low level infective pneumonitis, was significantly associated with maximal flows of MEFV.

The majority of the significant correlations between parametric data occurred in the $4.0 \mathrm{ppm}$ group. The directional characteristics of these correlations reflected an association between the proliferation or accumulation of connective tissue and disrupted flow in the airways, and to an extent the reduced compliance: elastin to $\mathrm{EFR}_{25},-0.895$; to $\triangle \mathrm{EFR}_{25}$, 
-0.903 ; to $\mathrm{R}_{\mathrm{us}}, 0.802$; and to $\mathrm{RV}, 0.707$; hydroxyproline to $R V, 0.826$; to $\mathrm{C}_{\mathrm{DYN}},-0.748$; and Iung weight to $\mathrm{RV}, 0.752$.

Significant rank correlations of pathology with either functional or compositional indices were concentrated in the 1.4 and 4.0 ppm groups (Table 25). Generally with increasing lung damage, maximum flows during the forced volume effort $\left(\Delta E F R_{25}\right)$ were diminished while lung volumes increased $\left(R V, F R C_{b}\right)$. Minute volumes were inversely correlated with the pathology indices within the $4.0 \mathrm{ppm}$ group, indicating a fall in ventilation with increased severity of the acrolein induced lesion. The $\mathrm{DLCO}_{\mathrm{sb}}$ of the $1.4 \mathrm{ppm}$ group was inversely correlated with the pathology scores. This inverse relationship was a consistent finding except in the case of the $0.4 \mathrm{ppm}$ animals. Significant inverse associations were found between the pathology index and elastin as well as hydroxyproline concentration in the $1.4 \mathrm{ppm}$ group (Table 25). Although not significant, the inverse relationship was evident in the control and low dose groups. However, a positive correlation was demonstrated in the $4.0 \mathrm{ppm}$ animals, statistically significant in the case of elastin.

Discriminant Analysis. Stepwise discriminant analysis was used to identify those normalized pulmonary function and lung composition parameters which best distinguished the four exposure groups. This technique selected and linearly combined a set of discriminating variables which forced the exposure groups to be as distinct as possible. When completed, the effectiveness of the derived discriminating function was checked by using it to classify the animals originally studied.

All of the lung composition data used in these analyses were expressed as a function of dry lung weight (Table 24). When stepwise discriminant analysis was applied to data from al1 exposure groups, hydroxyproline, 
elastin, and DNA were required for discrimination of the groups; hydroxyproline had the greatest discriminating power. The firșt discriminating function based on these variables explained $83.9 \%$ of the linear dispersion of the exposure groups. When this classification function was used to categorize the animals, 57\% were correctly classified (Table 26). When the same analysis was applied to the respiratory physiology data (Table 26) $\mathrm{DLCO}_{\mathrm{sb}}, \mathrm{FRC}_{\mathrm{b}}$, and $\mathrm{EFR}_{25}$ were the most discriminating variables. The first canonical variables explained $91.4 \%$ of the linear dispersion of the groups. The classification function based on these variables correctly classified $57.5 \%$ of the cases (Table 26). If both the respiratory physiology and lung composition data were used in the stepwise discriminant analysis, $65.3 \%$ of the animals were correctly placed with the resulting classification function (Table 26). The discriminating variables in this case were $\mathrm{FRC}_{\mathrm{b}}$, $\mathrm{DLCO}_{\mathrm{sb}}$, EFR25, and hydroxyproline. The dispersion of the individual animals, as well as the group centroids, based on the first and second discriminant functions (canonical variables) is illustrated in Appendix $\mathrm{H}$.

Because of the marked differences observed in the $4.0 \mathrm{ppm}$ animals, relative to the other exposure groups, the same analyses and classification procedures were conducted but with the high dose group deleted. When the analysis was limited to the biochemical parameters of the $0.0,0.4$, and $1.4 \mathrm{ppm}$ exposure groups, hydroxyproline and DNA proved to be the most discriminating. The first canonical variable explained $91.8 \%$ of the linear dispersion among the three groups and the classification function correctly grouped $55.1 \%$ of the rats (Table 27 ). Stepwise discriminant analysis on normalized respiratory physiology data from these three groups found $\mathrm{EFR}_{25}$. to be the most discriminating parameter. The first discriminant function based on this variable explained $100 \%$ of the 1 inear dispersion of the groups. However, the resulting classification function properly classified only 
$53.1 \%$ of the animals in these three exposure groups (Table 27). EFR 25 , hydroxyproline, and DNA surfaced as the most discriminating variables when both respiratory physiology and lung composition data were used in the analysis. The first discriminating function based on these variables explained $64 \%$ of the linear dispersion among the groups and the second discriminating function accounted for the other $36 \%$. The dispersion of the individual animals in these three groups based on these discriminant functions is illustrated in Appendix $H$. Sixty-seven percent of the animals were successfully categorized with this classification function (Table 27).

Stepwise discriminant analysis was also performed on the data from the possible pair combinations of the control, 0.4 , and 1.4 ppm exposure groups to determine which parameters were most discriminating between the groups. The results of these analyses and the success of the resulting classification functions in placing the test animals into their respective groups have been presented in Table 28. Hydroxyproline concentration consistently appeared as the most discriminating lung composition variable either alone or in conjunction with DNA. When the control and $1.4 \mathrm{ppm}$ groups were compared using respiratory physiology data only, no combination of the measured parameters provided significant linear dispersion between the groups. When the control and $1.4 \mathrm{ppm}$ groups were compared on the lung composition data alone or in conjunction with the respiratory function parameters, hydroxyproline and DNA appeared as the discriminating variables. The slightly different success rate in classifying these animals (Table 28) was due to the difference in sample size; if the data set for an animal was incomplete it could not be used in the analysis. Of the pulmonary function variables, $\mathrm{EFR}_{25}$ consistently provided significant linear dispersion between the 0.4 and $1.4 \mathrm{ppm}$ exposure groups. 
Table 24. Variables Used in the Pearson and Spearman Correlations and the Discriminant Analysis of Pulmonary Function, Lung Composition, and Pathology Data.

PULMONARY FUNCTION PARAMETERS

UNNORMALIZED

1. Heart rate (HR)

2. Tidal volume $\left(V_{T}\right)$

3. Transpulmonary pressure $\left(P_{L}\right)$

4. Frequency of breathing ( $f$ )

5. Minute volume $\left(\dot{\mathrm{V}}_{\mathrm{E}}\right)$

6. Functional reserve capacity $\left(\mathrm{FRC}_{\mathrm{b}}\right)$

7. Upstream airway resistance $\left(R_{u s}\right)$

NORMALIZED TO FUNCTIONAI RESERVE CAPACITY DETERMINED BY DILUTION (FRC $\left.{ }_{d}\right)$

1. Resistance $\left(R_{L}\right)$

2. Dynamic compliance $\left(C_{\mathrm{DYN}}\right)$

3. Quasi-static compliance determined by chord slope $\left(\mathrm{QSC}_{\mathrm{Cs}}\right)$

4. Quasi-static compliance determined by steep slope $\left(\mathrm{QSC}_{S S}\right)$

NORMALIZED TO TOTAI IUNG CAPACITY DETERMINED BY DILUTION (TLC $d$ )

1. Expiratory reserve volume (ERV)

2. Inspiratory capacity (IC)

3. Diffusing capacity for $C O$ measured by rebreathing ( $\left(\mathrm{DLO}_{\mathrm{rb}}\right.$ )

4. Diffusing capacity for $\mathrm{CO}$ measured by single breath ( $\mathrm{DLCO}_{\mathrm{Sb}}$ )

5. Trapped gas $\left(F R C_{b}-F R C_{d}\right)$

6. Residual volume (RV)

NORMALIZED TO VITAL CAPACITY (VC)

1. Peak expiratory flow (PEF)

2. Expiratory flow rate at $X \%$ vital capacity, where $X=10,25$, or 50 $\left(E F R_{X}\right)$

3. Difference in the flow at $25 \%$ vital capacity above or below that volume estimated by a chord slope drawn from EFR50 to EFR $\left(\triangle E F R_{25}\right)$

LUNG COMPOSITION PARAMETERS

NORMALIZED TO DRY WEIGHT

1. Lung weight

2. Protein

3. Elastin

4. Collagen

PATHOLOGY

Scores (Table 13) were ranked and used only in the Spearman correlations. 
Table 25. Pearson Correlation Coefficients of Pulmonary Physiology vs. Lung Composition Data and Spearman Rank Correlation Coefficients of Ranked Pathology Scores vs. Ranked Pulmonary Physiology and Lung Composition Data ${ }^{a}$

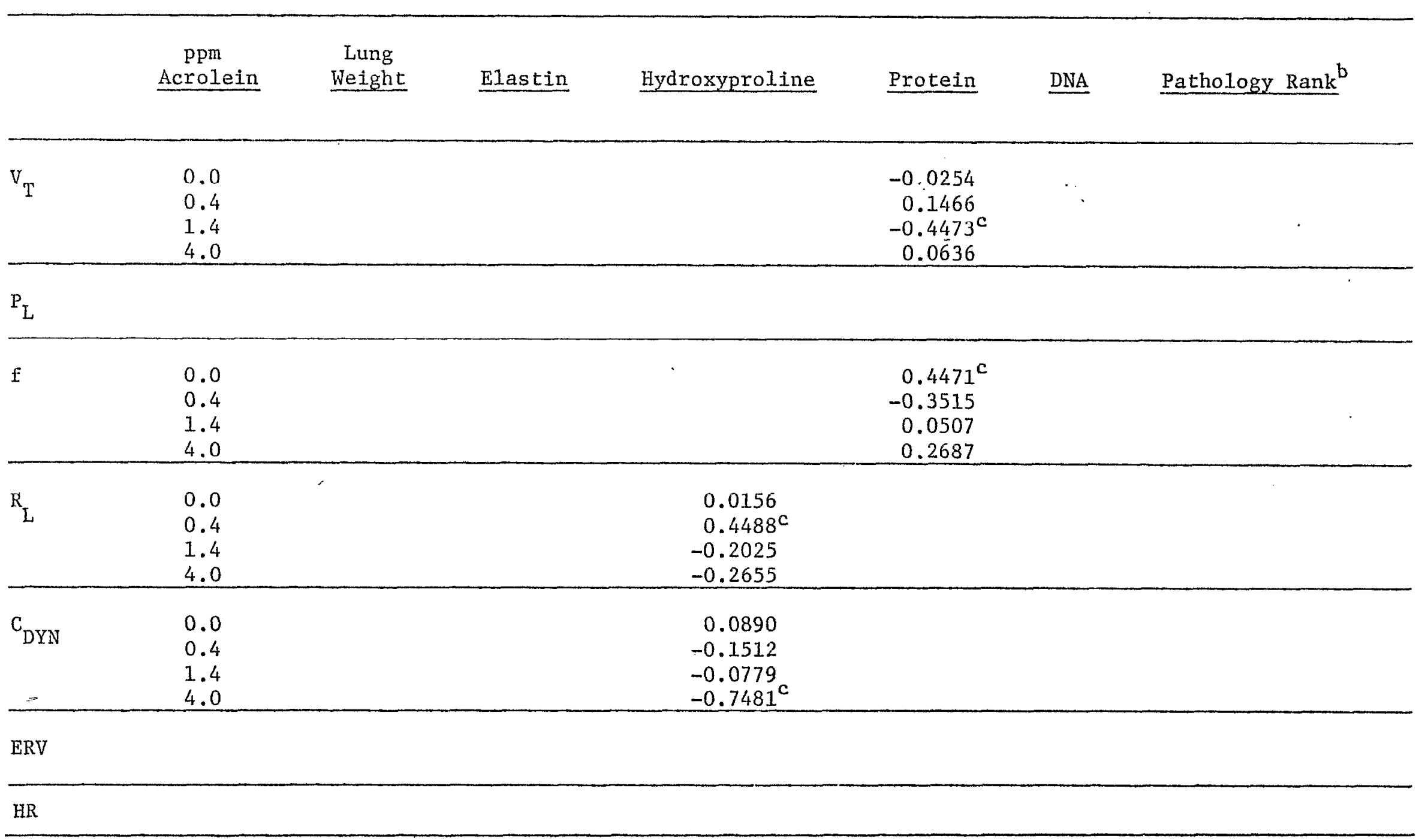


Table 25 - continued

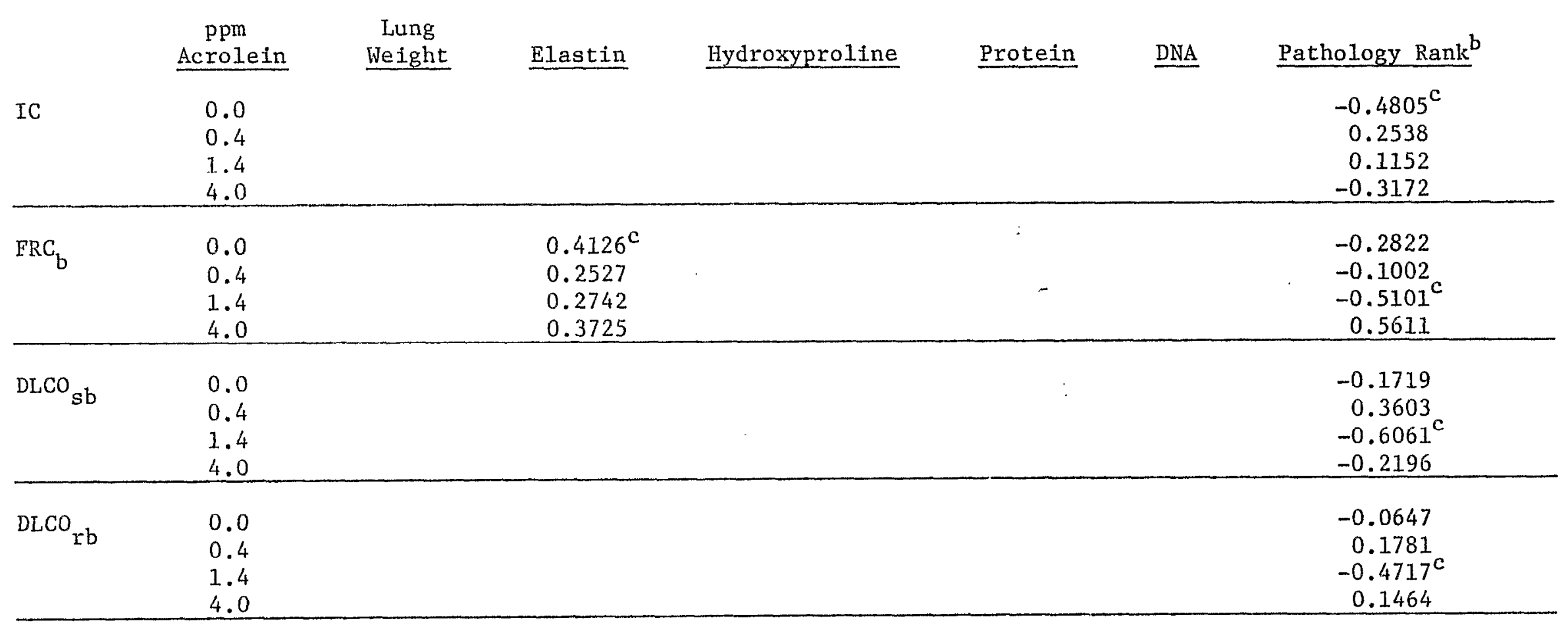

$\mathrm{QSC}_{\text {sS }}$

\begin{tabular}{|c|c|c|c|}
\hline \multicolumn{4}{|c|}{$\mathrm{QSC}_{\mathrm{cs}}$} \\
\hline $\mathrm{PEF}$ & $\begin{array}{l}0.0 \\
0.4 \\
1.4 \\
4.0\end{array}$ & $\begin{array}{r}0.4119^{c} \\
0.3746 \\
-0.2704 \\
0.3247 \\
\end{array}$ & $\begin{array}{r}0.4912^{c} \\
0.0369 \\
0.3972 \\
-0.1220 \\
\end{array}$ \\
\hline
\end{tabular}


Table 25 - continued

\begin{tabular}{|c|c|c|c|c|c|c|c|}
\hline $\mathrm{EFR}_{50}$ & $\begin{array}{c}\begin{array}{c}\text { ppm } \\
\text { Acrolein }\end{array} \\
\\
0.0 \\
0.4 \\
1.4 \\
4.0 \\
\end{array}$ & $\begin{array}{l}\text { Lung } \\
\text { Weight } \\
\end{array}$ & Elastin & Hydroxyproline & $\begin{array}{c}\text { Protein } \\
0.5606^{c} \\
0.3818 \\
-0.2796 \\
0.0607 \\
\end{array}$ & $\underline{\mathrm{DNA}}$ & $\begin{array}{c}\text { Pathology Rank }^{\mathrm{b}} \\
0.5239^{\mathrm{c}} \\
0.0402 \\
0.4494^{\mathrm{c}} \\
-0.3660 \\
\end{array}$ \\
\hline $\mathrm{EFR}_{25}$ & $\begin{array}{l}0.0 \\
0.4 \\
1.4 \\
4.0 \\
\end{array}$ & & $\begin{array}{l}-0.2995 \\
-0.0551 \\
-0.0018 \\
-0.8955^{c} \\
\end{array}$ & & $\begin{array}{l}\ddots \cdot \\
-\end{array}$ & & $\begin{array}{r}0.4175^{c} \\
-0.1752 \\
0.3680 \\
-0.6343 \\
\end{array}$ \\
\hline \multicolumn{8}{|l|}{$\mathrm{EFR}_{10}$} \\
\hline$\Delta \mathrm{EFR}_{25}$ & $\begin{array}{l}0.0 \\
0.4 \\
1.4 \\
4.0 \\
\end{array}$ & & $\begin{array}{r}-0.2067 \\
-0.0547 \\
0.0139 \\
-0.9028^{c} \\
\end{array}$ & " & & - & $\begin{array}{r}0.1179 \\
-0.3314 \\
0.1828 \\
-0.8295^{c} \\
\end{array}$ \\
\hline $\mathrm{R}_{\text {us }}$ & $\begin{array}{l}0.0 \\
0.4 \\
1.4 \\
4.0 \\
\end{array}$ & & $\begin{array}{r}0.1452 \\
0.3465 \\
-0.0222 \\
0.8023^{c} \\
\end{array}$ & & & & \\
\hline $\mathrm{RV}$ & $\begin{array}{l}0.0 \\
0.4 \\
1.4 \\
4.0 \\
\end{array}$ & $\begin{array}{r}-0.0018 \\
-0.1373 \\
0.0053 \\
0.7515^{\mathrm{c}} \\
\end{array}$ & $\begin{array}{r}0.0064 \\
-0.1600 \\
0.1670 \\
0.7067^{\mathrm{c}} \\
\end{array}$ & $\begin{array}{r}0.0138 \\
-0.3671 \\
0.2634 \\
0.8257^{\mathrm{c}} \\
\end{array}$ & & & $\begin{array}{r}0.0925 \\
-0.3667 \\
-0.1767 \\
0.8295^{\mathrm{c}} \\
\end{array}$ \\
\hline VE & $\begin{array}{l}0.0 \\
0.4 \\
1.4 \\
4.0 \\
\end{array}$ & $\begin{array}{r}0.4645^{c} \\
-0.2903 \\
-0.1828 \\
-0.6649 \\
\end{array}$ & & & $\begin{array}{r}0.4238^{c} \\
-0.2459 \\
-0.0787 \\
0.2799\end{array}$ & & $\begin{array}{r}-0.0287 \\
0.0192 \\
-0.0791 \\
-0.8295^{c}\end{array}$ \\
\hline
\end{tabular}


Table 25 -- continued

\begin{tabular}{|c|c|c|c|c|c|c|c|}
\hline & $\begin{array}{c}\text { ppm } \\
\text { Acrolein } \\
\end{array}$ & $\begin{array}{c}\text { Lung } \\
\text { Weight }\end{array}$ & Elastin & Hydroxyproline & Protein & DNA & Pathology Rank ${ }^{\mathrm{b}}$ \\
\hline $\begin{array}{l}\text { Pathology } \\
\text { Rank }\end{array}$ & $\begin{array}{l}0.0 \\
0.4 \\
1.4 \\
4.0\end{array}$ & & $\begin{array}{r}-0.2169 \\
-0.2763 \\
-0.4471^{c} \\
0.8051^{c} \\
\end{array}$ & $\begin{array}{r}-0.0401 \\
-0.1444 \\
-0.4509^{c} \\
0.4636\end{array}$ & & $\begin{array}{r}0.0696 \\
-0.4395^{c} \\
0.1613 \\
-0.1220 \\
\end{array}$ & 。 \\
\hline
\end{tabular}

$a_{0 n 1 y}$ sets of correlation coefficients where at least one association was statistically significant ( $\left.<<0.05\right)$ are 1isted.

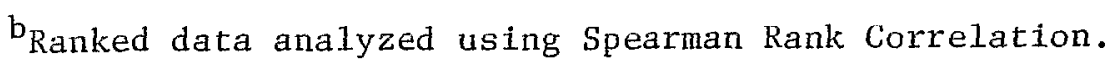

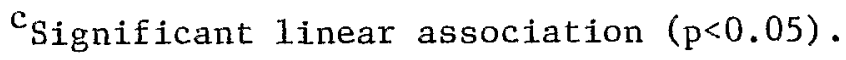


Table 26. Categorization of Fischer 344 Rats Exposed to $0.0,0.4,1.4$, or $4.0 \mathrm{ppm}$ Acrolein by a Classification Function Derived from Stepwise Discriminant Analysis of Selected Parameters.

Lung Composition Data

Number of Cases Classified into Group

Percent Correct

Group

$\begin{array}{llll}0.0 & 0.4 & 1.4 & 4.0\end{array}$

$\begin{array}{rrrrrr}0.0 & 17 & 4 & 3 & 0 & 70.8 \\ 0.4 & 8 & 7 & 8 & 0 & 30.4 \\ 1.4 & 1 & 6 & 15 & 0 & 68.2 \\ 4.0 & 0 & 0 & 3 & 5 & .5 \\ \text { Total } & 26 & 17 & 29 & 5 & \end{array}$

Pulmonary Function Data

Number of Cases Classified into Group

Group

\begin{tabular}{llll}
0.0 & 0.4 & 1.4 & 4.0 \\
\hline
\end{tabular}

0.0

0.4

1.4

4.0

13

4

16

4

3

61.9

4

6

1

0

6

69.6

30.0

17

77.8

Tota1

26

26

14

7

57.5

Lung Composition and Pulmonary Function Data

Number of Cases Classified into Group

Group

0.0

0.4

1.4

4.0

Total



$$
16
$$

3

3

0

22

0.4

1.4

23

21

$\begin{array}{rrr}3 & 2 & 0 \\ 13 & 7 & 0 \\ 5 & 12 & 0 \\ 0 & 2 & 6\end{array}$

6

Percent Correct

76.2

56.2

60.0

75.0

65.3 
Table 27. Categorization of Fischer 344 Rats Exposed to 0.0, 0.4, or 1.4 ppm Acrolein by a Classification Function Derived from the Discriminant Variables Defined by Stepwise Discriminant Analysis of Selected Parameters

Lung Composition Data

Number of Cases Classified into Group

Group
0.0
0.4
1.4

Tota1

0.0
$0.4 \quad 1.4$

$\begin{array}{rr}6 & 1 \\ 7 & 9 \\ 6 & 14\end{array}$

\section{Percent Correct}

70.8

30.4

63.6

55.1

Pulmonary Function Data

Number of Cases Classified into Group

Percent Correct

\begin{tabular}{|c|c|c|c|c|}
\hline \multirow{2}{*}{\multicolumn{5}{|c|}{ Group }} \\
\hline & & & & \\
\hline 0.0 & 11 & 5 & 5 & 52.4 \\
\hline 0.4 & 3 & 17 & 3 & 73.9 \\
\hline 1.4 & 7 & 7 & 6 & 30.0 \\
\hline Total & 21 & 29 & 14 & 53.1 \\
\hline
\end{tabular}

Lung Composition and Pulmonary Function Data

Number of Cases Classified into Group

Percent Correct

Group

$\begin{array}{lll}0.0 & 0.4 & 1.4\end{array}$

0.0

0.4

1.4

16

2

3

5

13

14

76.2

56.5

2

19

21

67.2

Total

23 
Table 28. Discriminating Variables Determined by Stepwise Discriminant Analysis and Correct Categorization of Animals with the Resulting Classification Function After Analysis of Selected Data Sets from Rats Exposed to $0.0,0.4$, or $1.4 \mathrm{ppm}$ Acrolein

\begin{tabular}{|c|c|c|c|c|}
\hline Variable & & 0.0 vs. 0.4 & $0.0 \mathrm{vs} .1 .4$ & 0.4 vs. 1.4 \\
\hline $\begin{array}{l}\text { Lung } \\
\text { Composition }\end{array}$ & $\begin{array}{c}\text { \% Correct } \\
\text { Classification } \\
(n)\end{array}$ & $\begin{array}{ll}75.0 & 69.6 \\
(24) & (23) \\
\end{array}$ & $\begin{array}{rr}95.8 & 59.1 \\
(24) & (22) \\
\end{array}$ & $\begin{array}{ll}87.0 & 50.0 \\
(23) & (22) \\
\end{array}$ \\
\hline $\begin{array}{l}\text { Parameters } \\
\text { Only }\end{array}$ & $\begin{array}{c}\text { Discriminating } \\
\text { Variable(s) }\end{array}$ & $\begin{array}{c}\text { Hydroxyproline } \\
\text { DNA }\end{array}$ & $\begin{array}{c}\text { Hydroxyproline } \\
\text { DNA }\end{array}$ & $\begin{array}{c}\text { Hydroxyproline } \\
\text { DNA }\end{array}$ \\
\hline $\begin{array}{l}\text { Respiratory } \\
\text { Physiology }\end{array}$ & $\begin{array}{c}\% \text { Correct } \\
\text { Classification } \\
(\mathrm{n})\end{array}$ & $\begin{array}{ll}81.0 & 82.6 \\
(21) & (23)\end{array}$ & \multirow[b]{2}{*}{ None ${ }^{\mathrm{a}}$} & $\begin{array}{ll}91.3 & 30.0 \\
(23) & (20)\end{array}$ \\
\hline $\begin{array}{l}\text { Parameters } \\
\text { Only }\end{array}$ & $\begin{array}{c}\text { Discriminating } \\
\text { Variable(s) }\end{array}$ & $\begin{array}{c}\mathrm{DLCO}_{\mathrm{sb}} \\
\mathrm{R}_{\mathrm{L}} \\
\mathrm{EFR}_{25}\end{array}$ & & $\mathrm{EFR}_{25}$ \\
\hline $\begin{array}{l}\text { Lung } \\
\text { Composition } \\
\text { and } \\
\text { Respiratory }\end{array}$ & $\begin{array}{c}\text { \% Correct } \\
\text { Classification } \\
(\mathrm{n}) \\
\end{array}$ & $\begin{array}{l}82.6 \\
(23) \\
\end{array}$ & $\begin{array}{r}65.0 \\
(20) \\
\end{array}$ & $\begin{array}{r}30.0 \\
(20) \\
\end{array}$ \\
\hline $\begin{array}{l}\text { Physiology } \\
\text { Parameters }\end{array}$ & $\begin{array}{c}\text { Discriminating } \\
\text { Variable(s) }\end{array}$ & $\begin{array}{l}\mathrm{DLCO}_{\mathrm{Sb}} \\
\mathrm{R}_{\mathrm{L}} \\
\mathrm{EFR}_{25}\end{array}$ & $\begin{array}{c}\text { Hydroxyproline } \\
\text { DNA }\end{array}$ & $\mathrm{EFR}_{25}$ \\
\hline
\end{tabular}

None of the variables provided significant discriminating power. 


\section{DISCUSSION}

The mortality observed in the 4.0 ppm chamber predominantly occurred during the first three weeks of exposure. A similar mortality pattern was reported for Wistar rats exposed to $4.9 \mathrm{ppm}$ acrolein (32) (6 hour/day, 5 days/week) and Sprague-Dawley derived animals exposed to $4.0 \mathrm{ppm}$ acrolein (33). None of the female Fischer 344 rats exposed to $4.0 \mathrm{ppm}$ acrolein died, although they rapidy lost weight and remained at less than their starting weights throughout the exposure period. The change in rate of weight gain observed here was in agreement with other studies where rats were repeatedly exposed to similar acrolein concentrations (32-34).

When reviewing the organ-to-body weight ratios, it must be remembered that animals were necropsied six days after the final exposure, during which time the $4.0 \mathrm{ppm}$ group gained a considerable amount of weight. Therefore, the recorded organ-to-body weight ratios of the high dose group were probably different than they would have been if the animals were sacrificed immediately after exposures were terminated. The significantly greater absolute lung weight of the $4.0 \mathrm{ppm}$ rats was attributed to increased cellularity. Although severe focal edema was observed in these lungs, the water content was only $1.5 \%$ greater than that of control lungs. The increased lung-to-body weight ratio was the only changed ratio in the $4.0 \mathrm{ppm}$ group directly attributable to acrolein exposure. Although changes have been reported in the liver-tobody weight ratio of rats after exposure to acrolein $(33,35)$, such changes were not recorded here. Feron et a1. (32) did not observe changes in the liver-to-body weight ratios of rats of comparable weight to those in this study, repeatedly exposed to $4.9 \mathrm{ppm}$ acrolein for 13 weeks. The changes observed in the other organ-to-body weight ratios probably reflected the slower weight gain of the $4.0 \mathrm{ppm}$ exposure group, rather than a direct 
effect of acrolein exposure.

These investigations confirmed that the respiratory tract was the target organ system of inhaled acrolein. Although the insult delivered by exposure to $4.0 \mathrm{ppm}$ resulted in pulmonary injury severe enough to be $56 \%$ fata1, extra-pulmonary organs were unaffected. Acrolein exposure had no apparent effect on bone marrow and peripheral blood lymphocyte populations. Also, the reproductive potential of exposed animals was unimpaired.

The pattern of histological change in the respiratory tract of animals in this study was similar to those previously reported $(32,34)$. In one of the studies (32) marked pathology was observed in the nasal cavity of Wistar rats exposed to $0.4,1.4$, and $4.9 \mathrm{ppm}$ acrolein for 13 weeks. Similarly, the nasal turbinates of the animals in this study showed an apparent dose dependent increase in submucosal lymphoid aggregates. However, rhinitis was only occasionally observed among the high dose animals in this study.

Contrary to the reports of acrolein toxicity for pulmonary macrophages $(35,36)$, increased numbers were found in the bronchiolar regions of the 4.0 ppm animals. However, these cells may have accumulated in the damaged bronchioles during the post-exposure period.

The absence of overt pathologic changes in several of the animals from the $4.0 \mathrm{ppm}$ exposure group was unexpected considering this acrolein concentration proved lethal to $56 \%$ of the male rats exposed. This marked intra-group variability was also evident in the $1.4 \mathrm{ppm}$ group. Reasons for the observed intra-group variability are unclear, but genetic heterogeneity may have been responsible.

Follow-up histopathological examination was conducted on the exposed male rats used in the reproductive studies. These animals were necropsied after being maintained under non-SPF conditions for 10 weeks post-exposure. 
A histopathology report on the findings in these animals has been provided in Appendix I. In brief, marked changes from control histology occurred only in the $4.0 \mathrm{ppm}$ exposure group. A clustering of foamy intraalveolar macrophages attended by mononuclear intraseptal hypercellularity, both changes resembling low grade interstitial pneumonitis, were evident. Low grade subacute bronchitis was also observed. These changes were not considered specific to acrolein exposure; however, the limitation of these findings to the high dose group suggested an obvious association. Exposure to $4.0 \mathrm{ppm}$ acrolein may have significantly suppressed the intrapulmonary killing of naturally occurring pathogenic entities. Acrolein exposure has been reported to interfere with pulmonary antibacterial and antiviral defenses $(35,36)$. Bouley et al. (35) found that rats exposed to $0.55 \mathrm{ppm}$ acrolein for 18 days were more susceptible to airborne Salmonella centeritidis than air exposed controls. However, when rats were exposed for 63 days and then infected, the death rates were identical for control and acrolein exposed animals. Although the susceptibility of rats to pathologic agents after exposure to higher concentrations has not been explored, it appears that exposure to $4.0 \mathrm{ppm}$ may compromise the defense mechanisms of these animals for extended periods after exposure has been terminated. Within the control group the correlation of elastin with $F R C_{b}$, lung weight with $\dot{V}_{E}$, and protein with PEF, EFR 50 , and $\dot{V}_{E}$ simply indicated that large normal lungs have greater volumes and therefore greater maximum flows than smaller normal lungs. These associations are worthy of mention because they were not maintained in any of the acrolein exposure groups. The pathology ranking, which in the control group probably reflected occasional low level infective pneumonitis, was also significantly associated with the maximum flow of MEFV. However, no comfortable explanation for this association can be offered. 
A substantial decrement in pulmonary function was observed in animals exposed to $4.0 \mathrm{ppm}$ acrolein. The depressed flow-volume effort, the leftward shift of the quasi-static compliance curve, and the enlarged lung volumes suggested obstructive airway lesions. This overall functional impairment was consistent with the marked increase in connective tissue and the histological damage observed in this group. The increased connective tissue concentration, particularly elastin, was significantly associated with the distortion observed in the effort-independent limb of the MEFV curve $\left(\triangle E F R_{25}\right)$ and with the loss of maximum flow $\left(E_{F R} R_{25}\right)$. The depression of the flow-volume curve $\left(\Delta \mathrm{EFR}_{25}\right)$ in this group was also significantly correlated with the ranked scores of total lung injury. A significant association was also found between upstream airway resistance and elastin concentration. Presumably, the bronchiolar epithelial lesion observed in the $4.0 \mathrm{ppm}$ group resulted in local connective tissue proliferation which accounted, in part, for the overall increased collagen and elastin concentrations.

Parenchymal damage attributable to $4.0 \mathrm{ppm}$ acrolein was confined to the peribronchiolar regions. Although scattered macrophage accumulations accompanied foci of edema, these lesions were apparently too disperse and localized to reduce functional compliance, an indicator of gross restriction. In fact, before normalization to the corresponding increase in vital capacity, raw static compliance (QSC slope) was significantly elevated. This phenomena has been reported in growing animals, where unadjusted lung compliance increased with lung volume (37). However, after acrolein exposure the reduced specific compliance (QSC slope/FRC ), which represented the lung at a relaxed end-tidal volume, did indicate significant restriction. Therefore, a proportionately greater fraction of the independent regions 
of the deep lung may have been significantly injured, which resulted in the markedly lower specific compliance. The $337 \%$ increase in trapped air. volume, $100 \%$ when expressed as a function of $\mathrm{TLC}_{\mathrm{d}}$, indicated that these rats were typically breathing at high Iung volume (FRC $\mathrm{d}_{\mathrm{d}}$ or end-tidal volume). Because compliance of the normal lung falls with increasing volume, adjustment of the FRC by the trapped air volume would shift normal tidal breathing down the QSC curve. This would bring the compliance values of the $4.0 \mathrm{ppm}$ animals into the normal range. A similar adjustment would also account for the apparent fall in $C_{D Y N} / F R C_{d}$.

The expeditious washout of $\mathrm{N}_{2}$ in the 4.0 ppm rats reflected tissue changes which increased the time constants of air turnover within the lungs. Stiffening of the airways and parenchyma, perhaps in conjunction with a reduction in lung compartmentalization, could account for these observations. The increased connective tissue concentrations in this exposure group would also support these observations; however, no generalized lesion suggestive of either interstitial or focal fibrosis was remarkable. The accelerated air turnover within the lung may have provided the ventilatory advantage to the undamaged lung needed to maintain adequate gas exchange. Unfortunately, blood gas determinations were not made in this study. However, diffusion of $\mathrm{CO}$ was elevated in these animals, probably as a function of lung volume, as it again fell within the control range when normalized to TLC.

The degree to which compensatory growth of injured lung may have biased the assessment of pulmonary function, particularly in the $4.0 \mathrm{ppm}$ group, must be considered. Replacement of lung tissue (hyperplasia) and hypertrophy of lung cells after pneumonectomy in young animals lacking a fixed mediastinum has been reported (38). Compensatory growth capability wanes during the final stages of growth; development and maturation of the rat lung is complete 
at approximately 14 weeks of age. The animals used here were approximately 13 weeks old and in the final stages of lung development when first exposed to acrolein. Although the phenomena of compensatory lung growth has not been reported in lungs acutely damaged by toxic agents, it was certainly suggested by the data reported here. In spite of enlarged lung volume (TLC), the expression of volume per gram of tissue virtually eliminated any differences from control values. Normalization of the QSC curves to VC (functioning lung) yielded compliance curves typical of controls. The DLCo as well as normalized DLCO (TLC) suggested increased lung tissue which apparently functioned normally. Finally, the increases observed in total connective tissue, protein, and DNA content were reduced when the increased lung size was taken into account. The fact that the ratios among these constituents did not change across exposure groups indicated a change in the amount, but not the composition of lung tissue in the $4.0 \mathrm{ppm}$ group. The reality of biological variability certainly presented itself in this study, particularly in the $4.0 \mathrm{ppm}$ exposure group. While $56 \%$ of the male rats died during the exposure regime, only 6 of the 9 animals assessed physiologically exhibited overt histological damage, and only 7 of the 9 demonstrated functional changes distinct from the controls. The two animals with the least functional damage were also free of histologic injury. The third animal with unremarkable histologic change exhibited only minor functional deficit.

Exposure to $0.4 \mathrm{ppm}$ acrolein resulted in airway changes which suggested greater rigidity or stability of the small airways. All flows, particularly those in the effort independent region of the forced expiratory curve, were significantly elevated relative to control values. The lower than control $R_{\text {us }}$, which reflected airway patency, may have allowed unusually high air 
flow at low lung volume. These "supra-normal" flows were not affected by adjustment to lung volume. The slight rightward shift of the QSC curve indicated a mild restriction, possibly the result of parenchymal stiffening. Such rigidity would result in augmented flow dynamics. However, connective tissue changes did not correlate with the flow or compliance changes observed in this exposure group, and acrolein associated pathology was not apparent.

Without data from the 0.4 and $4.0 \mathrm{ppm}$ groups, the functional response of the animals exposed to $1.4 \mathrm{ppm}$ would, at best, have been uninterpretable, and at worst, misleading. Overall, the animals in this group did not differ functionally from the controls. Other than the slight but significant elevation in DLCO/TLC, only suggestive functional differences were evident. With the exception of the hydroxyproline concentration, none of the lung constituents changed from control values. However, the ranked pathology scores of the animals in this group were significantly associated with their elastin as well as hydroxyproline concentrations.

Pulmonary function tests are limited in that they describe the overall function of a complex system which possesses tremendous compensatory capability. Therefore, similar lesions may have different functional effects, depending on their location in the respiratory tree. Conversely, different lesions may result in similar functional changes, such as direct obstruction of small airways versus airway flaccidity. Therefore, lesions which differ in character, quality, or location may each independently or interdependently alter function. Such summation over the entire respiratory system produces a composite functional picture. Under the exposure regime studied, acrolein may have produced distinct lesions which expressed themselves in a contradictory or compensatory manner. The extremes of 
the functional effects were observed at 0.4 and $4.0 \mathrm{ppm}$, while these effects essentially cancelled in the $1.4 \mathrm{ppm}$ group and resulted in an apparentiy normal intermediate response.

Those variables from the array of data available which most effectively separated the exposure groups were selected by stepwise discriminant analysis. Among the lung composition parameters hydroxyproline concentration consistently appeared as a discriminating variable. However, DNA frequently added additional discriminating power to the lung composition variables. Among the pulmonary function variables, $\mathrm{DLCO}_{s b}, \mathrm{EFR}_{25}, \mathrm{FRC}_{\mathrm{b}}$, and $\mathrm{R}$, proved to be the most discriminating. Considering the individual variability in response to acrolein exposure discussed earlier, the classification functions performed adequately. The only exception noted was in the $1.4 \mathrm{ppm}$ group which could not be distinguished from controls on the basis of pulmonary function.

Many of the above mentioned variables and their associated discriminating power may be useful indicators of pulmonary health after exposure to toxic agents. On the other hand, these discriminating variables may be peculiar to acrolein exposed animals. The possibility that a limited number of variables may surface as discriminating when stepwise discriminant analysis has been applied to data from studies involving a variety of agents and animals spectes should not be overlooked. Should this be the case, testing regimes which include pulmonary function and/or composition assessment, could concentrate on those variables which frequently surface as discriminators.

The functional tests, conducted on rats after exposure to acrolein, were a more sensitive indicator of subtle pulmonary changes induced by this compound than was light microscopic histopathology. The imposed MEFV maneuver was most sensitive and indicated significant small airway damage 
at all exposure levels. Connective tissue composition was also more indicative of low level irritant exposure than was histopathologic examination, although it was less sensitive than functional assessment. However, the lung composition data strongly supported the functional observations. The rather conventional instrumentation required for these biochemical assessments make this information more widely available among inhalation laboratories than the pulmonary function data. Although the functional battery provided the best information concerning the pulmonary health of exposed animals, placement of animals in their appropriate exposure groups was most successful when the compositional and functional data were combined.

Similar relative sensitivities of these investigative approaches were also observed with ozone (39). Analogous studies using these approaches will be conducted on a variety of toxic agents to determine whether this relative sensitivity is peculiar to certain classes of agents or if it is a generalized phenomena. Also, the fact that functional changes occur without detectable structural changes at the light microscopy level leads to the yet unanswered question; are there ultrastructure abnormalities in the lungs of animals showing subtle functional changes? 
REFERENCES

1. Dalgren, S. E. et a1. (1972). Virchows Arch. Abt. B. Ze11path., 11:211.

2. Denine, E. P. et a1. (1971). Toxicol. Appl. Pharmacol. 19:416.

3. Kensler, C. J. and Battista, S. P. (1963). New Engl. J. Med. 269:1161.

4. Amdur, R. A. et al. (1972). Cancer Res. 32:2519.

5. Fassett, D. W. (1962). Aldehydes and Acetals. In: "Industrial Hygiene and Toxicology," Vol. II, (F. A. Patty, ed.), Interscience Publishers, New York, NY, pp. 1959-1989.

6. Kruysse, A. (1971). Acute Inhalation Toxicity of Acrolein in Hamsters, Central Institute for Nutrition and Food Research TNO, Rep. No. R 3516 , Zeist, The Netherlands.

7. Smyth, H. F., Jr. (1956). Amer. Ind. Hyg. Asso. Quart. 17:129.

8. Murphy, S. D. et a1. (1963). I. Pharmaco1. 141:79.

9. Watanabe, T. and Aviado, D. M. (1974). Toxicol. App1. Pharmaco1. 30:201.

10. Munsch, N. et al. (1973). FEBS Lett. $30: 286$.

11. Silverman, J. et al. (1979). Lab. Anim. Sci. 29:209.

12. Katz, M. (ed.) (1977). "Methods of Air Sampling and Analysis," 2nd Ed., American Public Health Association, Washington, D.C., pp. 300-303.

13. Mead, J. and Whittenberger, J. L. (1953). J. AppI. Physio1. 5:779.

14. Takezawa, J. et a1. (1980). J. App1. Physio1. 48(6):1052.

15. Dulois, A. B. et al. (1956). J. Clin. Invest. 35:322.

16. Kanner, R. E. and Morris, A. H. (1975). "Clinical Pulmonary Function Testing," Section IV, Intermountain Thoracic Society, 1616 South 11th, E., Salt Lake City, Utah, 84105.

17. Bergman, I. and Loxley, R. (1963). Anal. Chem. 35:1961.

18. Naum, Y. and Morgan, T. E. (1973). Anal. Biochem. 53:392.

19. Hartree, E. F. (1972). Ana1. Biochem. 48:422.

20. Burton, K. (1956). Biochem. J. 62:315.

21. Schneider, E. L., et al. (1978). In: "Methods in Cell Biology," Vo1. 20, (D. M. Prescott, ed.), Academic Press, New York, New York, pp. $379-409$. 
22. Triman, K. L., et al. (1975). Cytogenet. Cell Genet. 15:166.

23. Bruce, W. R. and Hedd1e, J. A. (1979). Can. J. Genet. Cyto1. 21:319.

24. Wyrobek, A. Y. and Bruce, W. R. (1975). Proc. Nat. Acad. Sci. U.S.A. $72: 4425$.

25. Connor, M. K., et al. (1975). Chromosoma 74:51.

26. Goto, K. et al. (1975). Chromosoma $53: 223$.

27. Tice, R. R., et al. (1975). Nature 256:1642.

28. Tice, R. R. et a1. (1978). Mutat. Res. 58:293.

29. Sokal, R. R. and Rohlf, F. J. (1969). "Biometry", W. H. Freeman and Co., San Francisco, CA, pp. 515-520.

30. Dunn, 0. J. (1964). Techometrics 6:241.

31. Dixon, W. J. and Brown, M. B. (eds.) (1979). "BMOP-79 Biomedical Computer Programs P-Series," University of California Press, Berkeley, CA, pp. $711-$ 733.

32. Feron, V. J. et al. (1978). Toxicol. 9:47.

33. Kutzman, R. S. et al. (in press). J. Environ. Path. Toxicol.

34. Lyon, J. P. et al. (1970). Toxicol. Appl. Pharmaco1. 17:726.

35. Bouley, G. et al. (1976). Ann. Occup. Hyg. 19:27.

36. Voisin, C. et al. (1979). Nouv. Presse Med. 8:2089.

37. Mauderly, J. L. (1979). Exp. Aging Res. 5:497.

38. Kaufman, S. L. (1980) . Inter. Rev. Exp. Path. 22:131.

39. Kutzman, R. S. (1981). Sixty-two Exposure Day Study in Fischer 344 Rats Exposed to Three Concentrations of Ozone (Brookhaven National Laboratory, Informal Report 29084), report submitted to the National Toxicology Program. 
APPENDIX A

ACROLEIN: CHEMICAL AND PHYSICAL INFORMATION 
ACROLEIN

Chemical Abstract Services Registry Number: 107-02-8

Chemical Abstract Name: 2-Propenal

Other synonyms: acraldehyde; acrylic aldehyde; allyl aldehyde; propenal; prop-2-en-1-a1; 2-propen-1-one

Chemical structure: $\quad \mathrm{CH}_{2}=\mathrm{CH}_{2}-\mathrm{C}_{-\mathrm{H}}^{=0}$

Molecular weight: 56.06

Boiling point: $52.5^{\circ} \mathrm{C}(\mathrm{a})$

Melting point: $\quad-87.7^{\circ} \mathrm{C}$ (a)

Density: $d_{4}^{20} 40.8410$ (a)

Solubility: Soluble in water, ethanol, ether, and acetone (a)

Volatility: Vapor pressure at $17.5^{\circ} \mathrm{C}$ is $200 \mathrm{~mm}$ (b)

Stability: Flash point, $-26.1^{\circ} \mathrm{C}$ (c); polymerizes spontaneously, particularly in the presence of light, alkali, or strong acid (d)

Conversion factor in air: $1 \mathrm{ppm}=2.3 \mathrm{mg} / \mathrm{m}^{3}$

Acrolein: Air Pollution Information

Threshold Iinit value: USA: $0.1 \mathrm{ppm}\left(0.25 \mathrm{mg} / \mathrm{m}^{3}\right) 1974$ (e)

Threshold odor concentration: Population Identification Threshold $50 \%$ : $0.1 \mathrm{ppm}(f)$

Population Identification Threshold $100 \%$ : $0.21 \mathrm{ppm}$ (f) 
a. Dean, John A., ed. (1979). Lange's Handbook of Chemistry, 12th ed., McGraw-Hi11, USA, pp. 7-64 - 7-65.

b. Perry, R. H. and Chilton, C. H., eds. (1973). Chemical Engineer's Handbook, 5th ed., McGraw-Hill, USA, pp. 3-49.

c. Anon. (1972). Fire Protection Guide on Hazardous Materials, 4th ed., Boston, MA, National Fire Protection Association, pp. 325m-19, $49-29-49-30$

d. Windholz, M., ed. (1976). The Merck Index, 9th ed., Merck \& Co., Rahway, NJ, P. 17 .

e. Federal Registry, Vol. 39, no. 125 (June 1974) - Subpart G: Occupational Health and Environmental Control.

f. Manuf. Chem. Assoc., "Research on Chemical Odor,", Part 1, Oct., 1958. 
APPENDIX B

CHEMICAL METHOD FOR ANALYSIS OF CHAMBER ACROLEIN CONCENTRATION 
From: "Methods of Air Sampling and Analysis," 2nd Edition, pp. 300-303. M. Katz, ed., American Pub.Iic Health Association, Washington, D.C.

\section{Tentative Method of Analysis for Low Molecular Weight Aliphatic Aldehydes in the Atmosphere}

\section{Principle}

1.1 Formaldehyde. acrolein and low molecular weight aldehydes are collected in $1 \pi$ :aHSO: solution in midget impingers. Formaldehy de is meisured in an aliquot of the collection medium by the chromotropic acid procedure. acrolein b) a modified mercuric-shloride-hexylresorcinol procedure, and $C_{:}-C_{:}$aldehydes by a gas chromatographic procedure. The method permits the analysis of

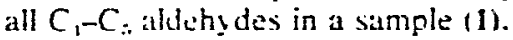

The sampling procedure is not applicable for the determination of alcohols. esters or kelones in atmospherie samples. since bisulfite does not efficiently collect these materials. How ever. should some of these compounds be present in the atmosphere. their presence may be indicated by the appearance of peaks corresponding to their retention times in the chromatograms. The retention times for several of these compounds are shown along with the aldehydes in Tuble 115:1.

\section{Range and Sensitivity}

2.1. At sumpling rates of 21 min over a 1 hr period. the following minimum concentrations can be determined:

$\mathrm{CH} . \mathrm{O}$ :

$\mathrm{CH}_{3} \mathrm{CHO}$ :
0.02 ppim

$0.02 \mathrm{ppm}$
$\mathrm{CH}$. $\mathrm{CH}_{\mathrm{CHO}} \mathrm{CHO}$
$\left(\mathrm{CH}_{;}\right){ }_{2} \mathrm{CHCHO}$ :
$0.03 \mathrm{ppm}$
$\mathrm{CH}_{2}=\mathrm{CHCHO}$
$0.03 \mathrm{ppm}$
$0.01 \mathrm{ppm}$

Shorter sampling periods are permissitle for higher consentrations.

\section{Interferences}

\subsection{FURMALDFHIDE.}

3.1.1 The chromotropic acid proceJure has very litule interference from other aldehydes. Saturated aldehydes give less than $0.01 \%$ prositive interference. and the unsaturated aldehyde acrolein results in a few per cent posinive interference. EIhand and higher molecular weight allohols and olefins in mixtures with formaklehyde are negative interferences. Howeber. sonientrations of alochols in air ate uxudly much lower than formaldehy de concentrations and. therefore. are not a veriuus inierference.

3.1.2 Phenols result in a 10 10 $24 \%$ negative interference when present at an 8:1 excess aver formaldehyde. They are. houever. ordinarily present in the itmosphere at lesser concentrations than formaldehyde and. therefore. are not a serious interference.

3.1.3 Ethylene and propylene in a 10:1 excess uver formuldehy de result in a 
5 to $10 \% \mathrm{c}$ negative interference and 2-methyl-1. 3-butadiene in a 15:1 excess over formaldehyde showed a $15 \%$ negative interference. Aromatic hy drocarbons also constitute a negative interference. It has recently been found that cyclohexanone causes a bleathing of the final color.

3.2 ACROLEIY.

3.2.1 There is no interference in the acrolein detarmination from ordinary quantities of sulfur dioxide. nitrogen dioxide. ozone and most organic air pollutants. A slight interference occurs from dienes: $1.5 \%$ for 1.3-butadiens and $2 \%$ for 1.3 . pentadient. The red color produced by some other aluehydes and undetermined materials does not intertise in spectrophotumetric medsurement.

\section{Precision and Accuracy}

4.1 Known standards san be determined to within $=$ s. of the true value.

Table 115:I. Retentiun Times for Aldehydes. Ketones. Alcohols and Fsters

\begin{tabular}{|c|c|}
\hline Compound & $\begin{array}{l}\text { Time: } \\
\text { Retention } \\
\text { minutes }\end{array}$ \\
\hline Acetaldehyde & 3.5 \\
\hline Propionalueh de & 4.6 \\
\hline Acutune & 5.1 \\
\hline Isobutylraldehy de & 5.5 \\
\hline Mathylakohol & 6.1 \\
\hline Ethyl alcohol & 6.7 \\
\hline Isopropyl alcohol & 6.7 \\
\hline Ethyl acetats & 7.0 \\
\hline n-Butyraldehy de & 7.1 \\
\hline Methyl-ethyl ketone & 7.7 \\
\hline Isopentanal & 12.0 \\
\hline Crotunialuehy de & 14.0 \\
\hline
\end{tabular}

- Flus rate. temperature and conditions described in text.

Vo data are abailate on precision and als curacy for atmospheric samples.

\section{Apparatus}

5.1 Aвsorbfr. All glass standard midget impingers are acceptable. A train of $?$ bubblem in series is used.

5.2 Arr PLip. A pump capable of draw- ing at least 21 of air'min for 60 min through the sampling train is required.

5.3 Air Meterivg Device. Either a limiting orifice of approximately I 1 min capacity or a glass fiuw meter can be used. Cleining and frequent valibration are required if a limiting orifice is used.

5.t SPECTRUPHOTOUETER. This instrument should be eapable of measuring the developed colors at $605 \mathrm{~nm}$ and 580 $\mathrm{nm}$. The absurption banus are rather nar. row, and thus a lower absorptivity may be expected in a broad-band instrument.

5.5 GAs CHRUnA JOGR.sPH, with hydrogen Hame detector and injection port sleeve (Varian $12(6)$ or equivalenn.

5.6 BIJLIVG WATER BITH.

\section{Reagerts}

6.1 DEIERMIS RIOU OF FORMAL$D E H>D E$.

6.1.2 Sudium furmuldetude bisulfite (E.K. P(x+50)

6.1.3 Chromentropic acid sendiam salt. EK P330. 0.5 in water. Filter just before using. Stable for ons $u$ seck if kegt refrigerated. graule.

6.1.t Sulfiric acid. Cons reagent

6.2 Deter.HISATIOS OF ACROLEIN.

6.2.1 $\mathrm{HgCl}_{\mathrm{g}}-$-hteritresorcinol. $0.30 \mathrm{~g}$ $\mathrm{HgCl}_{2}$ and $2.5 \mathrm{~g}+\mathrm{hex}$ hlresorcinul are dissolved in $50 \mathrm{ml} 95 \% \mathrm{c}$ ethanol. (Stable at least 3 weeks if kept refrigerated.)

6.2.2 TCAA. To a I b bottle of trichloracetic acid add $23 \mathrm{ml}$ distilled water and $25 \mathrm{mi} 950 \mathrm{c}$ ethanol. Mix until all the TCAA has dissivlved.

6.3 COLlECTIO: MEDIUM. Sudium bisulfite. IT in water.

\section{Procedure}

7.1 Collectios uf Sabples. Two mideret impingers. eavth sontaining $110 \mathrm{ml}$ of $1 \%$ : vaHSO. are connested in serie's with Tygon tubing. These are followed by and connected to an emply impinger (for meter protection) and a dry test meter and a suurce of suction. During sampling the impingers are immersad in an ice bah. Sampling rale of 21 min ihould be mainlained. 
Sampling duration will depend on the concentration of aldehydes in the dir. One hr sampling time at $21 \mathrm{~min}$ is adequate for ambient concentrations.

After sampling is complete. the impingers are disconnected from the train. the inlet and outlet tubes are capped. and the impingers stored in an ice bath or at. $6 C$ in a refrigerator until analyses are per-" formed. Cold storage is necessary only if the acrolein determination cannot be performed within $4 \mathrm{hr}$ of sampling.

7.2 Axalysis of SaMples. (Each impinger is analyzed separately).

7.2.1 Formaldehyde (1) (2). Transfer a 2-ml aliquot of the absorbing solution to a $25-\mathrm{ml}$ graduated tube. Add $0.2 \mathrm{ml}$ chromotropic acid. and then, cautiously. 5.0 $\mathrm{ml}$ conc sulfuric acid. Mix well. Transfer to a boiling water bath and heat for $15 \mathrm{~min}$. Cool the samples and add distilled water to the $10-\mathrm{ml}$ mark. Cool, mix and transfer to a $16-\mathrm{mm}$ cuvette. reading the transmiltance at $580 \mathrm{~nm}$. A blank containing? $\mathrm{ml}$ of $1 \%$ sodium bisulfite should be run along with the samples and used for $100 \%$ $T$ setting. From a stanuard curve read $\mu \mathrm{g}$ of formaldehyde.

7.2.2 Acrolein (1) (3). To a $25-\mathrm{ml}$ graduated tube add an aliquot of the collected sample in bisulfite contuining no more than $30 \mu \mathrm{g}$ acrolein. Add $1 \%$ sodium bisulfite (if necessary) to a volume of $4.0 \mathrm{ml}$. Add $1.0 \mathrm{ml}$ of the $\mathrm{HgCl}_{2}-4-\mathrm{hex}_{\mathrm{y}} / \mathrm{resurcinul}$ reagent and $\mathrm{mix}$. Add $5.0 \mathrm{ml}$ of TCAA reagent and mix again. Insert in a boiling water bath for 5 to $6 \mathrm{~min}$. remove. and set aside until tubes reach room temperature. Centrifuge simples at $1500 \mathrm{rpm}$ for $5 \mathrm{~min}$ to clear slight turbidity. One hr after heating. read in a spectrophotometer at $605 \mathrm{~nm}$ against a bisulfite blank prepared in the same fashion as the samples.

7.2.3 $C_{\tau} C_{\text {: Aldehydes (1). }}$

a. ANALYTICAL COLLMV 12' $\times$ !'s" stainless steel pached with 15\% win Carbowax $20 \mathrm{M}$ un Chromosorb. 60 wo 80 mesh. followed by 5 ' $\times 1 / 8 "$ stainless steel Uncondinonylphthalate on frebrick, 100 to 200 mesh. prepared as follows: Ucon 50-HB-200, $1.5 \mathrm{~g}$. and $1.4 \mathrm{~g}$ of dinonylphthalate are dissolved in chloroform and added to $13 \mathrm{~g}$ of firebrick. The solvent is evaporated at room temperature and the column packed in the usual manner.

b. Injection port sletve: The inlet of the injection port contains a glass sleeve packed with solid $\mathrm{Na}_{2} \mathrm{CO}_{3 .}$. The $\mathrm{Na}_{2} \mathrm{CO}_{.}$is held in place with glass wool plugs.

c. Conditions:

Injection part lemperature. 160 to $170 \mathrm{C}$

Column temperature. $105 \mathrm{C}$

Detector temperalure. $200 \mathrm{C}$

Vitrogen carrier gas flow rate. $14 \mathrm{ml}$ min Hydrugen fou rate. $20 \mathrm{ml} / \mathrm{min}$

Combustion air fow rate, 400 'min

d. Procedure: A $4 \mu$ l sample of the bisulfite collection solution is injected into the packed sleeve at the injection port and the chromatogram is recorded. Table 114:1 show's the relative retention times for a series of aidehy des and kerones in the $C_{2}-C_{\text {: }}$. range.

\section{Calibration}

\subsection{FORMALDEHYDE.}

8.1.1 Preparation of standard curve. To a $1-1$ volumetric fiask add $0.4766 \mathrm{~g}$ sodium formaldehyde bisulfite and dilute to volume. This solution contains $0.1 \mathrm{mg}$ formaldehyde per $\mathrm{ml}$. Dilute to vbrain standard solutions containing 1.3 .5 and $7 \mu \mathrm{g}$ formaldehyde per $\mathrm{ml}$. Treat $2-\mathrm{ml}$ aliquots as described in the procedure for colur development. Read each at $580 \mathrm{~nm}$ affer hetting instrument at lofrc $T$ with the hlank. Using semilog paper. graph the respective concentrations vs. iransmittance.

\subsection{ACROL f.IS:}

8.2.1 Preparation of standard cune. To $250 \mathrm{ml}$ of $1 \%$ wdium bisulfite add 4.0 $\mu$ freshly distilled acrolcin. This yiclus a standard containing $13.4 \mu \mathrm{g} \mathrm{ml}$. To a series of tubes add 0.5 .1 .0 .1 .5 . and $2.0 \mathrm{ml}$ of standard. Adjust the volumes to $4.0 \mathrm{ml}$ with $15 c$ bisulfite and develup color as described above. Plot data on semi-log paper.

\section{$8.3 C_{y}-C_{5}$ Aldi.hides.}

8.3.1 Calibration. A mixed standard of $C_{2}-C_{5}$ aldehydes and ketones is prepared as follows:

a. Acetaldehyde-bisulfite solution: $0.336 \mathrm{~g} \mathrm{CH}_{\mathrm{:}} \mathrm{CHO} \cdot \mathrm{NaHSO}_{\mathrm{i}}(\mathrm{EK} 791)$ is dissolved in 11 of $19 \mathrm{NaHSO}$. This gives 
a solution containing $100 \mu \mathrm{g} \mathrm{ml}$ acetaldehyde.

b. To $10.0 \mathrm{ml}$ of the above solution are added $40.0 \mathrm{ml}$ of $1 \mathscr{T}_{\mathrm{C}}$. VaHSO $;$, and $8 \mu \mathrm{l}$ of a mixture of equal volumes of propanal. isobutanal. butanal. isopentanal. pentanal crotonaldehyde. acetone and butanone.

The final solution contains $20 \mu \mathrm{g} / \mathrm{ml}$ acetaldehyde and $0.02 \mu$ l of each of the $C$. $C_{i}$ aldehydes and ketones per $\mathrm{ml}$. Four $\mu \mathrm{l}$ of the standard are injected into the glass sleeve in the injection purt of the chromatugraph as described in the procedure. and the chromatugram is recorded.

\section{Calculations}

$(1.23 \mu \mathrm{g}$ formaldehy de $=1 \mu$ l (vol) at $25 \mathrm{C}$. and 760) Tors)

9.1 FOR UALDEHYDE. ppm formaldehyde $(\mathrm{CH}, \mathrm{O})=$

total micrograms of $\mathrm{CH}_{2} \mathrm{O}$ in simple

$$
1.23 \times \text { sample volume in liters }
$$

9.2 ACROLEIX.

(2.3 $\mu \mathrm{g}$ acrolein $=1.0 \mu \mathrm{l}(\mathrm{vol})$ acrolein $)$

$\mathrm{ppm}=\frac{\text { total } \mu \mathrm{g} \text { of acrulein in sample }}{2.3 \times \text { sample volume in liters }}$
9.3 Aldehydes. Calculation of unknown sample concentration is made on the basis of comparative peak heights bethe en standards and unknowns.

\section{Effect of Storage}

10.1 After sampling is complete. collection media are stored in an ice bath or refrigerator at $6 C$. Cold storage is necessary only if acrolein is to be determined. Under cold storage cunditions. analyses can be performed within $48 \mathrm{hr}$ with no deterioration of collected samples.

\section{References}

1. Levacot. D.A.. and M. Felosters. 1970. The Determination of Formaldetyde. Acrolein and Low Mulecular Weight Aldehydes in Inudustrial Emissions on a Single Collesed Sampla. JAPCA. 20:31?.

2. AMERICAY PLBLIC HeAlth Assoclerrov. 1977. Methods of Air Sampling and Andysin. Ind ed. p. 297. Wishington. D.C.

3. Ibid. p. 297 .

Sublommittes 4 R. G. S.ath. Chairman

R. J. Brytis

M. FELOSTEIN

B. LEVAD̈IE

F. A. NILLER

E. $R$ STEPHENS

$\therefore$ G. White 
APPENDIX C

LIST OF EXPOSURE DAYS ON WHICH WET CHEMICAL DETERMINATIONS OF CHAMBER CONCENTRATIONS WERE CONDUCTED 
1

2

3

4

5

7

8

9

10

16

18

21

23

26

28

29

31

33

35
36

76

39

78

40

42

83

85

45

87

47

89

49

51

54

56

57

59

62

65

67

70

72

74 
APPENDIX D

PHOTOCOPIES OF CHAMBER DATA SHEETS FOR FOUR RANDOMLY SELECTED EXPOSURE DAYS 


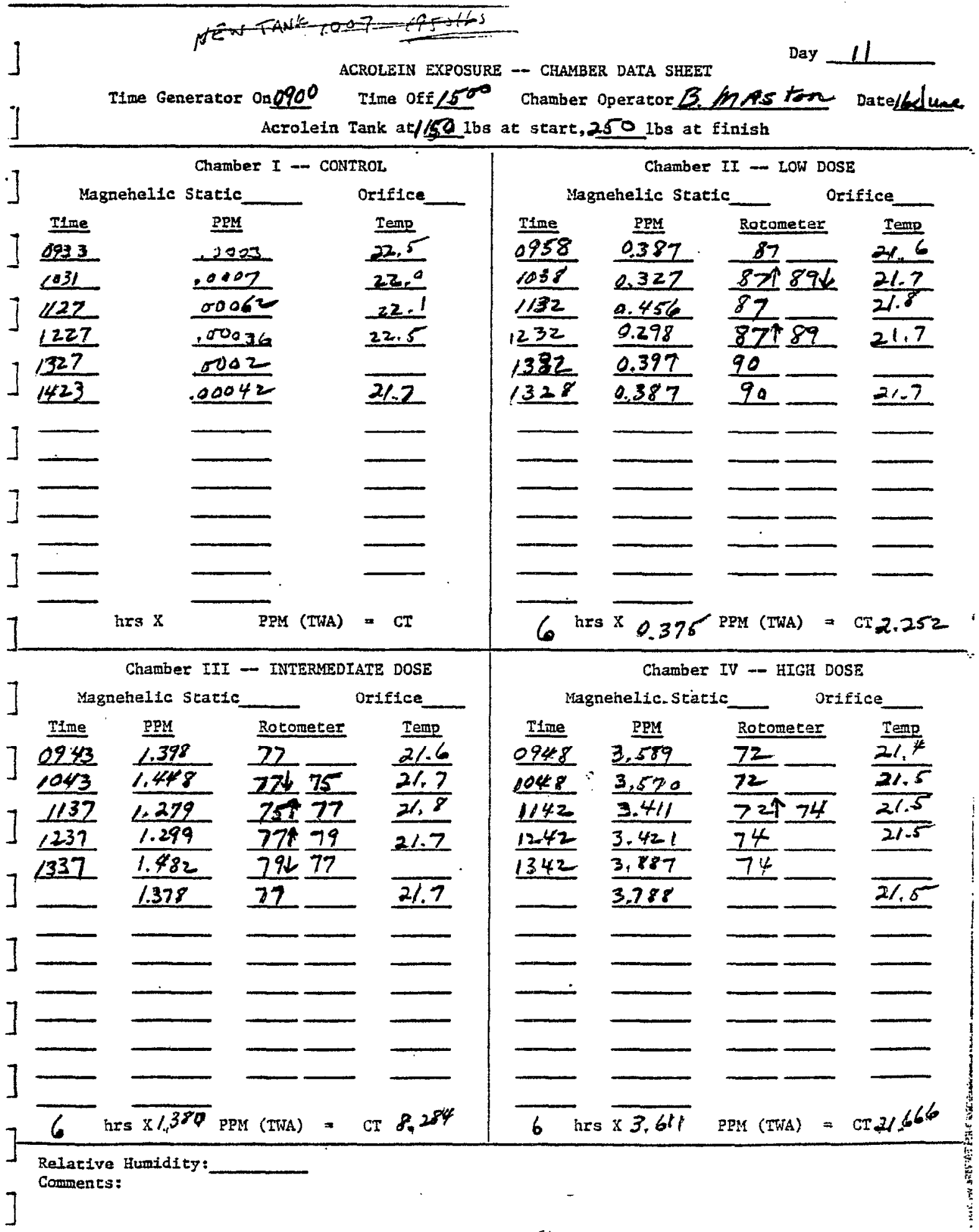




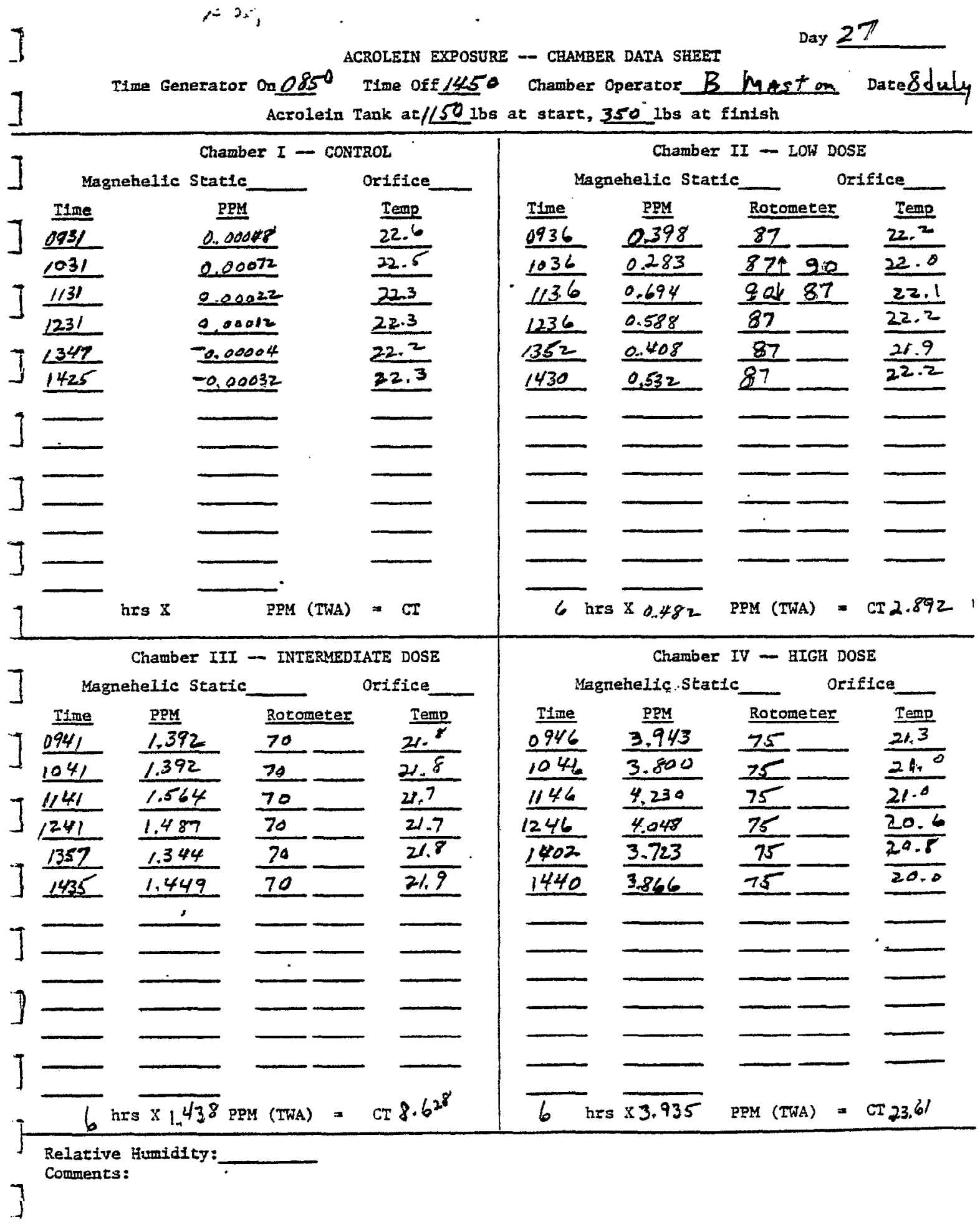




\section{APPENDIX E}

PULMONARY FUNCTION DATA FROM INDIVIDUAL FISCHER 344 RATS 


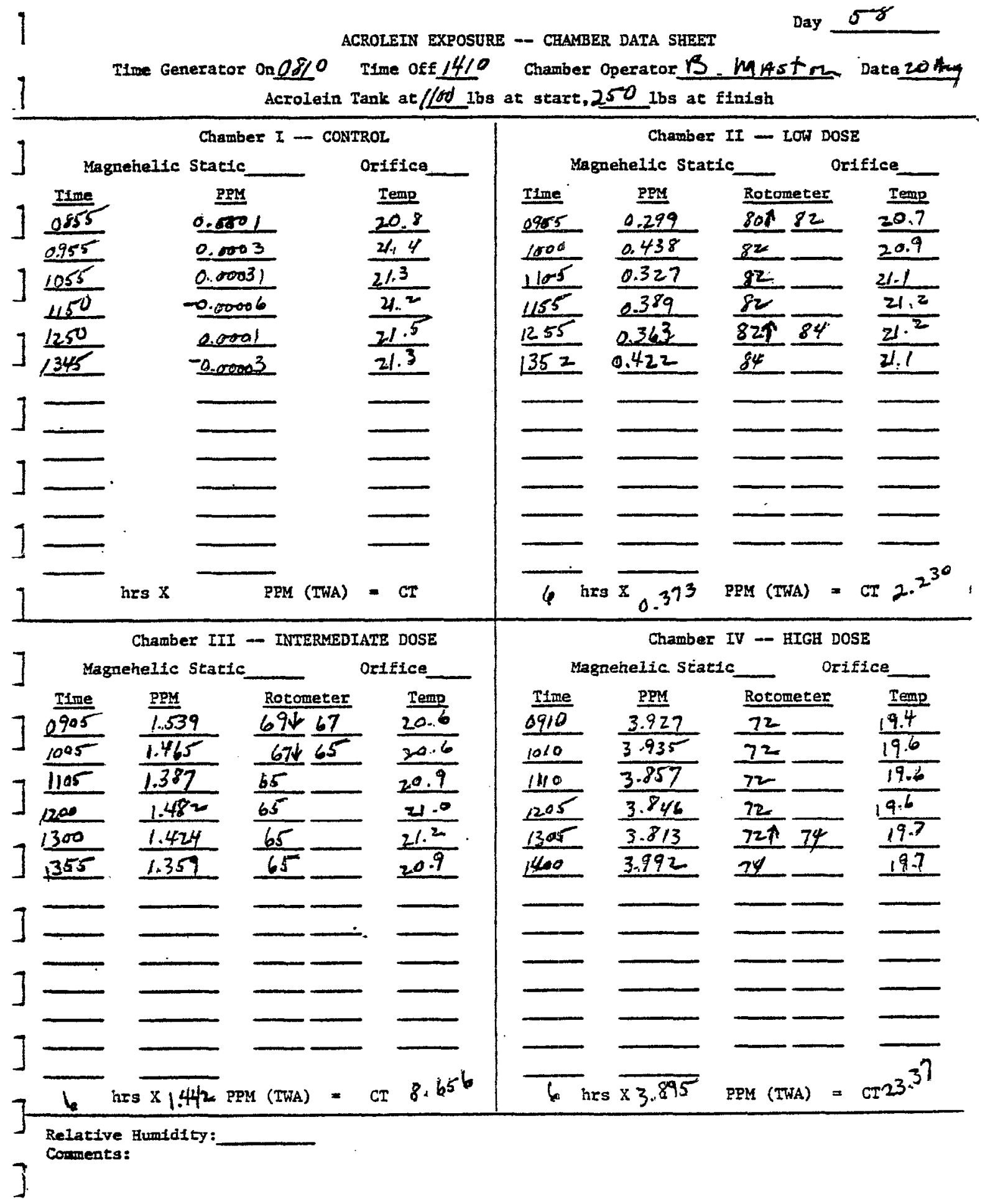







CCNTROL GROUP

\begin{tabular}{|c|c|c|c|c|c|c|c|c|c|c|}
\hline An 非 & $\mathrm{HR}$ & $\mathrm{V}_{\mathrm{T}}$ & $\mathrm{f}$ & $\underline{v}_{E}$ & $\Delta \mathrm{P}_{\mathrm{L}}$ & $\mathrm{R}_{\mathrm{L}}$ & $c_{D Y N}$ & $\mathrm{FRC}_{\mathrm{g}}$ & $\mathrm{FRC}_{\mathrm{b}}$ & $\mathrm{RV}_{\mathrm{d}}$ \\
\hline$\because \cdots$ & $\cdots$ & $\cdots$ & $\cdots$ & $\cdots+\cdots$ & $\cdots \cdots$ & $\cdots$ & $\cdots$ & $\ldots$ & $\cdots$ & $\cdots$ \\
\hline 5501. & 393 & 2.12 & 4 & 129.32 & 11.06 & 1,09 & 16 & 3.63 & 2.46 & 1,46 \\
\hline $\begin{array}{l}5502 \\
5503\end{array}$ & $\begin{array}{l}436 \\
453\end{array}$ & $\begin{array}{l}1.65 \\
1.59\end{array}$ & $\begin{array}{l}75 \\
60\end{array}$ & $\begin{array}{l}123.75 \\
108.15\end{array}$ & $\begin{array}{r}10.41 \\
6.97 \\
\end{array}$ & $\begin{array}{l}1,25 \\
1,05\end{array}$ & 123 & $\begin{array}{l}3.34 \\
2.61\end{array}$ & $\begin{array}{l}1.84 \\
1.87\end{array}$ & $\begin{array}{l}59 \\
.87\end{array}$ \\
\hline $\begin{array}{l}5517 \\
5518 \\
\end{array}$ & $\begin{array}{l}421 \\
4012\end{array}$ & $\begin{array}{l}1.59 \\
1.42\end{array}$ & $\begin{array}{l}52 \\
66\end{array}$ & $\begin{array}{l}92.68 \\
9.31 .31\end{array}$ & $\begin{array}{r}0.96 \\
119.28\end{array}$ & $\begin{array}{r}1.09 \\
.02\end{array}$ & $\begin{array}{r}22 \\
-16 \\
\end{array}$ & $\begin{array}{r}2.94 \\
2.69\end{array}$ & $\begin{array}{r}2.01 \\
4.12\end{array}$ & $\begin{array}{l}1.26 \\
2.82\end{array}$ \\
\hline 5519 & 351 & 1.43 & 110 & 165.88 & 9,51 & .93 & 13 & 2.53 & 3.48 & 2.23 \\
\hline $\begin{array}{l}5588 \\
5542\end{array}$ & $\begin{array}{l}421 \\
369\end{array}$ & $\begin{array}{l}1,82 \\
1,72\end{array}$ & $\begin{array}{l}69 \\
59\end{array}$ & $\begin{array}{l}125,58 \\
101.48\end{array}$ & $\begin{array}{r}14.36 \\
6.73\end{array}$ & $\begin{array}{r}42 \\
.25 \\
\end{array}$ & $\begin{array}{l}32 \\
.36\end{array}$ & $\begin{array}{l}2,74 \\
2,77\end{array}$ & $\begin{array}{r}3.34 \\
4.44\end{array}$ & $\begin{array}{l}1,59 \\
2.19\end{array}$ \\
\hline 5543 & 343 & 1.70 & 32 & 54,40 & 11.30 & 1,17 & .20 & 2.66 & 2. .48 & .48 \\
\hline 5544 & 3110 & 1.99 & EI & 113,43 & 7.72 & 48 & 27 & & 2.37 & \\
\hline 5598 & 0 & $=.06$ & 54 & 111.24 & 7.36 & -37 & .34 & 9.31 & 2.73 & 1.48 \\
\hline 5546 & 444 & 1.96 & EA & $1 E 5,44$ & 8.67 & .19 & .25 & 2.53 & 2.31 & 1,31 \\
\hline 5559 & 324 & 1.99 & 97 & $-19.3 \cdot 03$ & 8.7 .8 & .62 & .29 & 3,11 & 2.15 & 90 \\
\hline 5548 & 480 & 1,93 & $7 G$ & 146.68 & 8.22 & .97 & .25 & 2.95 & 2.15 & 1,53 \\
\hline 5542 & 421 & & 75 & 121,00 & 2,77 & 1,25 & 26 & 3.22 & 1.53 & $1.0^{3}$ \\
\hline 5550 & 444 & 1.58 & 77 & 121.56 & 2.62 & .70 & 26 & 2.73 & 2.73 & 1,61 \\
\hline $\begin{array}{l}5551 \\
5552\end{array}$ & 414 & 1.58 & E & 126.40 & $\begin{array}{r}4,50 \\
11,73\end{array}$ & $\begin{array}{r}59 \\
56\end{array}$ & .40 & $\begin{array}{l}3,00 \\
0.83\end{array}$ & $\begin{array}{l}2.21 \\
2.50\end{array}$ & $\begin{array}{l}1.33 \\
1.25\end{array}$ \\
\hline 5553 & 375 & 1.65 & 61. & 100.65 & 6.40 & .93 & .28 & 3.62 & 1.71 & .96 \\
\hline 5554 & 364 & 1.90 & El & -120.28 & 13.14 & 1,25 & 23 & 3,15 & 1,92 & .42 \\
\hline 5555 & 353 & 1.74 & en & 104.40 & 11,00 & -.05 & .12 & 3.19 & 2.35 & 1.1 \\
\hline $\begin{array}{l}5556 \\
5591\end{array}$ & $\begin{array}{l}365 \\
393\end{array}$ & $\begin{array}{l}1.87 \\
1.12\end{array}$ & $\begin{array}{l}24 \\
i 14\end{array}$ & $\begin{array}{l}140,28 \\
1 \geq 7,2 \varepsilon\end{array}$ & $\begin{array}{l}5,79 \\
4: 21\end{array}$ & .93 & $\begin{array}{l}123 \\
29\end{array}$ & 3,74 & $\begin{array}{l}2.29 \\
2.78\end{array}$ & 1.41 \\
\hline 5558 & 353 & 2,31 & 55 & 128,70 & 0.00 & .93 & .17 & 3.80 & 2.98 & 1.73 \\
\hline
\end{tabular}

Data missing because of technical difficulties are indicated by ${ }_{i}$ a, 0 . 
CCUTROL GROUH

\begin{tabular}{|c|c|c|c|c|c|c|c|c|c|}
\hline An $\#$ & VC & $\mathrm{TLC}_{\mathrm{d}}$ & $\mathrm{DLCO}_{\mathrm{sb}}$ & $\mathrm{QSC}_{\mathrm{sS}}$ & PEF & $\mathrm{EFR}_{50}$ & $\mathrm{EFR}_{25}$ & $\mathrm{EFR}_{10}$ & $\Delta \mathrm{EFR}_{25}$ \\
\hline 5501 & $\because .-25$ & 8.71 & $--2 \bar{z}$ & $--m=-$ & $\ddot{10.2}$ & $-m m-4$ & 63.4 & $\begin{array}{r}-7-2.9 \\
30.9\end{array}$ & $-12,20$ \\
\hline $\begin{array}{l}5502 \\
5503\end{array}$ & $\begin{array}{r}7.00 \\
8.50\end{array}$ & $\begin{array}{l}7,59 \\
8,32\end{array}$ & $\begin{array}{r}.175 \\
.215\end{array}$ & $\begin{array}{r}60 \\
1.91\end{array}$ & $\begin{array}{r}96.5 \\
106.1\end{array}$ & $\begin{array}{l}63.7 \\
96.5\end{array}$ & $\begin{array}{l}51,5 \\
45,0\end{array}$ & $\begin{array}{l}32.2 \\
16.1 \\
\end{array}$ & $\begin{array}{r}9.65 \\
-3.25\end{array}$ \\
\hline $\begin{array}{l}5517 \\
5518\end{array}$ & $\begin{array}{l}1,75 \\
2,25 \\
\end{array}$ & $\begin{array}{r}10.01 \\
12.12 .\end{array}$ & $\begin{array}{r}1239 \\
1274 \\
\end{array}$ & $\begin{array}{r}1.33 \\
1.08\end{array}$ & $\begin{array}{r}95.2 \\
10.9 .4\end{array}$ & $\begin{array}{r}75.9 \\
106.8 \\
\end{array}$ & $\begin{array}{l}54,1 \\
32,1\end{array}$ & $\begin{array}{r}28.3 \\
38.6 \\
\end{array}$ & $\begin{array}{l}16,15 \\
18,20\end{array}$ \\
\hline 5519 & 0.50 & 12,73 & .213 & .21 & 126.1 & 113,3 & 50,0 & 18,0 & $=.05$ \\
\hline $\begin{array}{l}5588 \\
5582\end{array}$ & $\begin{array}{r}9.75 \\
9.25\end{array}$ & $\begin{array}{r}11.34 \\
11.94\end{array}$ & $\begin{array}{r}224 \\
+212\end{array}$ & .89 & $\begin{array}{r}103,0 \\
21,0\end{array}$ & $\begin{array}{l}90,1 \\
82,4\end{array}$ & $\begin{array}{l}54,1 \\
50,5\end{array}$ & $\begin{array}{r}15.4 \\
-31.5 \\
\end{array}$ & $\begin{array}{l}9,05 \\
2,30\end{array}$ \\
\hline $\begin{array}{r}5543 \\
5544 \\
\end{array}$ & $\begin{array}{l}8,25 \\
8,50\end{array}$ & $\begin{array}{r}9,73 \\
0 ., 27 \\
\end{array}$ & $\begin{array}{r}.198 \\
-.212 \\
\end{array}$ & $\begin{array}{r}1.47 \\
0.25\end{array}$ & $\begin{array}{r}94.1 \\
8.2 .5\end{array}$ & $\begin{array}{l}75,1 \\
86,5\end{array}$ & $\begin{array}{r}49,7 \\
61,1\end{array}$ & $\begin{array}{r}16.7 \\
-29.6 \\
\end{array}$ & $\begin{array}{l}12,15 \\
12,65\end{array}$ \\
\hline 5598 & 9.50 & 10,98 & .123 & 1.85 & 112,0 & 88,2 & 41.2 & 11.6 & $-2,90$ \\
\hline $\begin{array}{r}5546 \\
-5559\end{array}$ & $\begin{array}{l}5.25 \\
2.13 \\
\end{array}$ & $\begin{array}{r}9.56 \\
10.03 \\
\end{array}$ & $\begin{array}{r}.217 \\
.211\end{array}$ & $\begin{array}{r}1.2 .9 \\
.8 .91\end{array}$ & $\begin{array}{r}87.5 \\
-82.1\end{array}$ & $\begin{array}{l}6 \% .4 \\
28.5\end{array}$ & $\begin{array}{r}13,8 \\
32.2 \\
\end{array}$ & $\begin{array}{l}23,2 \\
10.3\end{array}$ & $\begin{array}{r}2,60 \\
-7,05\end{array}$ \\
\hline $\begin{array}{r}5548 \\
5549\end{array}$ & $\begin{array}{r}8.87 \\
9.38\end{array}$ & $\begin{array}{r}10.40 \\
2.41 \\
\end{array}$ & $\begin{array}{r}.206 \\
-205 \\
\end{array}$ & $\begin{array}{r}.66 \\
-275 \\
-25\end{array}$ & $\begin{array}{r}115.3 \\
88.8 \\
\end{array}$ & $\begin{array}{l}36.2 \\
72.1\end{array}$ & $\begin{array}{r}47,6 \\
42,52 \\
\end{array}$ & $\begin{array}{r}27.0 \\
28.3 \\
\end{array}$ & $\begin{array}{r}4,50 \\
6.45 \\
\end{array}$ \\
\hline 5550 & 8.75 & 10,36 & -.245 & .20 & 103,0 & 90,1 & 61,8 & 31.5 & 10.75 \\
\hline $\begin{array}{l}5551 \\
5552\end{array}$ & $\begin{array}{l}8,93 \\
8,00\end{array}$ & $\begin{array}{l}10,26 \\
10.25\end{array}$ & $\begin{array}{r}.259 \\
.233\end{array}$ & $\begin{array}{r}0.80 \\
.75\end{array}$ & $\begin{array}{r}110.7 \\
90.1\end{array}$ & $\begin{array}{r}108,1 \\
76,6\end{array}$ & $\begin{array}{l}79,8 \\
38,6\end{array}$ & $\begin{array}{l}48.9 \\
14.2\end{array}$ & $\begin{array}{r}25,75 \\
.30\end{array}$ \\
\hline $\begin{array}{r}5553 \\
5554 \\
\end{array}$ & $\begin{array}{r}9,13 \\
0,38 \\
0.38\end{array}$ & $\begin{array}{r}10.09 \\
3.80\end{array}$ & $\begin{array}{r}.254 \\
.225 \\
\end{array}$ & $\begin{array}{r}.75 \\
-.86\end{array}$ & $\begin{array}{r}83.7 \\
-101.7\end{array}$ & $\begin{array}{r}61,8 \\
63,2\end{array}$ & $\begin{array}{r}15,4 \\
59,2 \\
\end{array}$ & $\begin{array}{r}3.2 \\
37.3 \\
\end{array}$ & $\begin{array}{r}15,50 \\
17,35 \\
\end{array}$ \\
\hline 5555 & 8,63 & 2.73 & .212 & .74 & 106.8 & 95,2 & 13,8 & 19,3 & $-3,80$ \\
\hline $\begin{array}{l}5556 \\
5591\end{array}$ & $\begin{array}{l}9,38 \\
9,38\end{array}$ & $\begin{array}{l}10.79 \\
10.66\end{array}$ & $\begin{array}{r}257 \\
+234\end{array}$ & .78 & $\begin{array}{r}90.1 \\
100.6\end{array}$ & $\begin{array}{l}04,4 \\
97,8\end{array}$ & $\begin{array}{l}27,0 \\
63,1\end{array}$ & $\begin{array}{r}3.9 \\
37.3\end{array}$ & $\begin{array}{r}-5,20 \\
14,20\end{array}$ \\
\hline 5558 & 9.25 & 10,98 & .251 & .63 & 104,3 & 91.1 & 34,7 & 10.3 & $=10,35$ \\
\hline
\end{tabular}


LOW $305 E$

\begin{tabular}{|c|c|c|c|c|c|c|c|c|c|c|}
\hline An 非 & $\mathrm{HR}$ & $\mathrm{V}_{\mathrm{T}}$ & $f$ & $\mathrm{~V}_{\mathrm{E}}$ & ${ }^{\Delta \mathrm{P}_{\mathrm{L}}}$ & $\mathrm{R}_{\mathrm{L}}$ & $\mathrm{C}_{\mathrm{DY}} \underline{\mathrm{N}}$ & $\mathrm{FRC}_{\mathrm{d}}$ & $\mathrm{FRC}_{\mathrm{b}}$ & $\mathrm{RV}_{\mathrm{d}}$ \\
\hline 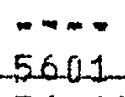 & 316 & $\begin{array}{l}--\infty \\
=0.06\end{array}$ & $-\infty$ & $-111-34$ & 12,73 & $\begin{array}{r}-7.4 \\
-53 \\
\end{array}$ & --10 & 30.0 & $\begin{array}{l}--m \\
1.39\end{array}$ & $=-189$ \\
\hline $\begin{array}{l}5602 \\
5687\end{array}$ & $\begin{array}{l}444 \\
369\end{array}$ & $\begin{array}{l}1,65 \\
1,50\end{array}$ & $\begin{array}{l}55 \\
71\end{array}$ & $\begin{array}{r}90.75 \\
112.89\end{array}$ & $\begin{array}{r}9,63 \\
1+44\end{array}$ & $\begin{array}{l}1.17 \\
50\end{array}$ & $\begin{array}{l}17 \\
12\end{array}$ & $\begin{array}{l}3,03 \\
3,00\end{array}$ & 4.20 & $\begin{array}{r}2.45 \\
.56\end{array}$ \\
\hline $\begin{array}{l}5617 \\
5613\end{array}$ & $\begin{array}{l}429 \\
369\end{array}$ & $\begin{array}{l}2.05 \\
1.99\end{array}$ & $\begin{array}{l}23 \\
73\end{array}$ & $\begin{array}{l}170,15 \\
155.22\end{array}$ & $\begin{array}{r}9.29 \\
12.83\end{array}$ & $\begin{array}{r}1.11 \\
-23\end{array}$ & $\begin{array}{l}120 \\
13\end{array}$ & $\begin{array}{l}2.51 \\
3.02\end{array}$ & $\begin{array}{l}3.72 \\
2.43 \\
\end{array}$ & $\begin{array}{r}2.47 \\
-1.23\end{array}$ \\
\hline 56.1. & 453 & 1,63 & 61 & 104.32 & 2.84 & -90 & .15 & 2.77 & 2.62 & 1.12 \\
\hline $\begin{array}{l}5697 \\
-5642 \\
5643 \\
5644\end{array}$ & $\begin{array}{r}332 \\
38: \\
387 \\
316 \\
\end{array}$ & $\begin{array}{l}1,60 \\
1,50 \\
1,65 \\
1,26\end{array}$ & $\begin{array}{r}67 \\
66 \\
85 \\
61\end{array}$ & $\begin{array}{l}107.20 \\
-102-26 \\
112.20 \\
102.36\end{array}$ & $\begin{array}{r}11,85 \\
9,61 \\
5,03 \\
4,88\end{array}$ & $\begin{array}{r}.31 \\
-93 \\
.16 \\
1.25\end{array}$ & $\begin{array}{r}14 \\
+12 \\
.36 \\
37\end{array}$ & $\begin{array}{l}2.68 \\
3.92 \\
2.60 \\
2.62\end{array}$ & $\begin{array}{l}2.45 \\
4.04 \\
1.71 \\
2.94\end{array}$ & $\begin{array}{r}.45 \\
3.54 \\
.21\end{array}$ \\
\hline 5665 & 405 & 1.87 & 85 & $15 \Omega, 25$ & 6.80 &. .72 & -35 & 2.93 & 5.24 & 3.24 \\
\hline $\begin{array}{l}5696 \\
5622\end{array}$ & $\begin{array}{l}300 \\
308\end{array}$ & $\begin{array}{l}2.27 \\
2,03\end{array}$ & 42 & $\begin{array}{r}186,14 \\
83,23\end{array}$ & $\begin{array}{l}5,64 \\
9,85\end{array}$ & $\begin{array}{r}128 \\
-\quad 62\end{array}$ & $\begin{array}{r}31 \\
-17\end{array}$ & $\begin{array}{l}2.76 \\
3.03\end{array}$ & $\begin{array}{r}2.58 \\
2.67\end{array}$ & $\begin{array}{r}1.33 \\
1.29\end{array}$ \\
\hline $\begin{array}{l}5649 \\
5650\end{array}$ & $\begin{array}{l}471 \\
400\end{array}$ & $\begin{array}{l}1,53 \\
1,61\end{array}$ & $\begin{array}{r}101 \\
50\end{array}$ & $\begin{array}{r}194.93 \\
94.95\end{array}$ & $\begin{array}{l}5,70 \\
5,6.7\end{array}$ & $\begin{array}{r}.23 \\
.20 \\
\end{array}$ & $\begin{array}{r}125 \\
-28\end{array}$ & $\begin{array}{r}2.95 \\
-3.01\end{array}$ & $\begin{array}{l}1.94 \\
2.80\end{array}$ & $\begin{array}{r}.94 \\
1.30 \\
\end{array}$ \\
\hline 5623 & 323 & $2.3 E$ & 70 & $-1 \in 4,5 n$ & Q.6.0. & 28 & -22 & 3.11 & 1.32 & 1,27 \\
\hline $\begin{array}{l}5652 \\
5694\end{array}$ & $\begin{array}{l}490 \\
375\end{array}$ & $\begin{array}{l}1,86 \\
1,53\end{array}$ & $\begin{array}{r}71 \\
53 \\
\end{array}$ & $\begin{array}{r}132.06 \\
81.05\end{array}$ & $\begin{array}{l}9.31 \\
2.69\end{array}$ & $\begin{array}{r}.93 \\
-155\end{array}$ & $\begin{array}{r}19 \\
35\end{array}$ & $\begin{array}{r}3.12 \\
2.86\end{array}$ & $\begin{array}{l}2.98 \\
3.04\end{array}$ & $\begin{array}{r}1.36 \\
-1.79\end{array}$ \\
\hline $\begin{array}{l}5695 \\
5655\end{array}$ & $\begin{array}{l}414 \\
412\end{array}$ & $\begin{array}{l}2.12 \\
1.87\end{array}$ & $\begin{array}{l}8 ? \\
2 ? \\
\end{array}$ & $\begin{array}{r}184.41 \\
134.64\end{array}$ & $\begin{array}{r}13.76 \\
7.19\end{array}$ & $\begin{array}{r}.70 \\
-28 \\
\end{array}$ & $\begin{array}{r}26 \\
-28 \\
\end{array}$ & $\begin{array}{r}3.46 \\
4.12 \\
\end{array}$ & $\begin{array}{l}2.74 \\
2.14\end{array}$ & $\begin{array}{l}1,54 \\
1,39\end{array}$ \\
\hline $565 t$ & 322 & 2.05 & 25 & -156.56 & $1 ; 92$ & -45 & -48 & -3.53 & 2.63 & 1,38 \\
\hline $\begin{array}{l}5657 \\
5696\end{array}$ & $\begin{array}{l}356 \\
407\end{array}$ & $\begin{array}{l}1.47 \\
1.80\end{array}$ & $\begin{array}{r}10.4 \\
.5 .5 \\
\end{array}$ & $\begin{array}{r}152.8 E \\
59.00\end{array}$ & $\begin{array}{l}5.18 \\
6.23\end{array}$ & $\begin{array}{l}1.17 \\
1,01\end{array}$ & $\begin{array}{r}18 \\
+24 \\
\end{array}$ & $\begin{array}{l}3,34 \\
2.74\end{array}$ & $\begin{array}{l}2.27 \\
2.64\end{array}$ & $\begin{array}{l}1.08 \\
1.39\end{array}$ \\
\hline
\end{tabular}




\begin{tabular}{|c|c|c|c|c|c|c|c|c|c|}
\hline An $\|$ & $\begin{array}{c}\mathrm{VC} \\
---\end{array}$ & $\mathrm{TLC}_{\mathrm{d}}$ & $\mathrm{DLCO}_{s b}$ & $\mathrm{QSC}_{\mathrm{SS}}$ & PEF & $\begin{array}{l}\mathrm{EFR}_{50} \\
\ldots-\ldots\end{array}$ & ${ }^{E_{2} R_{25}}$ & $\begin{array}{l}\mathrm{EFR}_{10} \\
\ldots .\end{array}$ & $\triangle \mathrm{EFR}_{25}$ \\
\hline $\begin{array}{l}5601 \\
5602\end{array}$ & $\begin{array}{l}9,25 \\
8,25\end{array}$ & $\begin{array}{l}10.14 \\
10,20\end{array}$ & $\begin{array}{r}.285 \\
-260 \\
\end{array}$ & $\begin{array}{r}1.80 \\
.52\end{array}$ & $\begin{array}{l}119.7 \\
108.1\end{array}$ & $\begin{array}{l}115,8 \\
101.2\end{array}$ & $\begin{array}{l}99,5 \\
20+8\end{array}$ & $30, ?$ & $\begin{array}{r}11,60 \\
12,25 \\
\end{array}$ \\
\hline 5687 & 9,50 & 10,06 & 1347 & $: .00$ & 117.1 & 104.9 & 69.5 & 38.6 & 17,05 \\
\hline 5612 & 8., D. & $10, A 2$ &, 24.8 & .57 & 113.3 & 10.9 .1 & 75,9 & 37,3 & 21,85 \\
\hline 5618 & 9,00 & 10.23 & .232 & .70 & 106,2 & 103,0 & 73,4 & 45,0 & 21,90 \\
\hline $\begin{array}{l}5619 \\
5622\end{array}$ & $\begin{array}{l}7,50 \\
7.96\end{array}$ & $\begin{array}{l}0.82 \\
0.41\end{array}$ & $\begin{array}{r}194 \\
1218\end{array}$ & $\begin{array}{r}.71 \\
.81\end{array}$ & $\begin{array}{l}127.4 \\
104,2\end{array}$ & $\begin{array}{r}125.5 \\
100.4\end{array}$ & $\begin{array}{l}90,1 \\
33,1\end{array}$ & $\begin{array}{r}16.3 \\
-399\end{array}$ & $\begin{array}{l}27.35 \\
12.90\end{array}$ \\
\hline 5042 & 7.00 & 10,54 & .275 & .56 & 90,5 & 91.4 & 58,2 & 38,6 & 22,50 \\
\hline 5643 & 1,50 & -6.71 & -214 & 1,00 & 29.1 & $82,-4$ & 46,3 & $\because 7,7$ & 5,10 \\
\hline $564 \mathrm{~A}$ & 7,00 & 7.94 & .203 & .69 & $101: 7$ & 99.1 & 74,6 & 37,3 & 25.05 \\
\hline 5645 & 6,25 & 11,99 & , 299 & 1.00 & 97.6 & $92, ?$ & 64,4 & 29.6 & 10,05 \\
\hline $\begin{array}{l}-5.662 \\
5602\end{array}$ & 411,50 & $-11, \varepsilon_{3}$ & -272 &, $9-1$ & $-121, \ldots$ & $-102,-2$ & $62+9$ & $-4 \div 6$ & $-11,1.02$ \\
\hline $\begin{array}{l}5692 \\
5699\end{array}$ & $\begin{array}{l}7.63 \\
7.50\end{array}$ & $\begin{array}{r}8,92 \\
8,44\end{array}$ & $\begin{array}{r}-223 \\
-215\end{array}$ & $\begin{array}{r}71 \\
-513 \\
-5\end{array}$ & $\begin{array}{l}104,9 \\
103,0\end{array}$ & $\begin{array}{l}101.7 \\
101,7\end{array}$ & $\begin{array}{l}86.9 \\
79.8\end{array}$ & $\begin{array}{r}28,3 \\
29.6\end{array}$ & $\begin{array}{l}16,05 \\
28,05\end{array}$ \\
\hline 5650 & 8.38 & 9,68 & 1224 & .56 & 88.8 & 79.8 & 35,4 & 15.4 & $\because 4,50$ \\
\hline $\begin{array}{l}5693 \\
5652\end{array}$ & $\begin{array}{l}8,50 \\
0.25\end{array}$ & $\begin{array}{r}9.77 \\
10.61\end{array}$ & 1241 & $\begin{array}{r}.75 \\
87\end{array}$ & 99,7 & 90.1 & 39,9 & 18.0 & $\begin{array}{r}-5,15 \\
11,60\end{array}$ \\
\hline $\begin{array}{l}5694 \\
5695\end{array}$ & $\begin{array}{l}9,00 \\
9,20\end{array}$ & $\begin{array}{l}10,79 \\
10,74\end{array}$ & $\begin{array}{r}258 \\
-1279\end{array}$ & .77 & $\begin{array}{r}87,5 \\
-83,7\end{array}$ & $\begin{array}{r}36,0 \\
82,-4\end{array}$ & $\begin{array}{l}65,6 \\
56,9\end{array}$ & $\begin{array}{r}36.0 \\
23.2\end{array}$ & $\begin{array}{l}22,15 \\
25,20\end{array}$ \\
\hline 5655 & 9.00 & 10,39 & .253 & .73 & 97,8 & 84.9 & 57.9 & 35,4 & 15,45 \\
\hline $\begin{array}{l}5656 \\
-5657\end{array}$ & $\begin{array}{l}9.00 \\
9.13\end{array}$ & $\begin{array}{r}10.38 \\
-15.21\end{array}$ & $\begin{array}{r}126 ? \\
+225 \\
\end{array}$ & .63 & $\begin{array}{r}101,0 \\
103,0\end{array}$ & $\begin{array}{l}55.8 \\
82.5\end{array}$ & $\begin{array}{l}69,5 \\
59,2\end{array}$ & $\begin{array}{l}47.0 \\
24,5\end{array}$ & $\begin{array}{r}21,90 \\
15,45\end{array}$ \\
\hline 5696 & 8.25 & 9,64 & 1233 & .67 & 113,3 & 100,8 & $6,3,1$ & 38.6 & 9,70 \\
\hline
\end{tabular}


INTERMELIATE DOSE

\begin{tabular}{|c|c|c|c|c|c|c|c|c|c|c|}
\hline An \# & $\mathrm{HR}$ & $\mathrm{v}_{\mathrm{T}}$ & $\mathrm{f}$ & $V_{E}$ & $\Delta \mathrm{P}_{\mathrm{L}}$ & $\mathrm{R}_{\mathrm{L}}$ & $C_{D Y N}$ & $\mathrm{FRC}_{\mathrm{d}}$ & $\mathrm{FRC}_{\mathrm{b}}$ & $R V_{d}$ \\
\hline$\ldots-\cdots$ & $\cdots$ & $\ldots$ & $\ldots-$ & $\ldots \ldots$ & $\ldots \ldots=$ & $\cdots+\infty$ & $\cdots$ & $\ldots$ & $\ldots$ & $\cdots$ \\
\hline 5701 & 387 & $1,8.7$ & 24 & 138,38 & 7.72 & -1.86 & -22 & 3.48 & 2.57 & 57 \\
\hline $\begin{array}{l}5702 \\
5703\end{array}$ & $\begin{array}{l}466 \\
462\end{array}$ & $\begin{array}{l}1,73 \\
1,71\end{array}$ & $\begin{array}{l}86 \\
5.4\end{array}$ & $\begin{array}{r}140,78 \\
82,34\end{array}$ & $\begin{array}{l}9,42 \\
5,03\end{array}$ & $\begin{array}{r}.59 \\
.27\end{array}$ & $\begin{array}{r}1.9 \\
24\end{array}$ & $\begin{array}{l}2.94 \\
2.77\end{array}$ & $\begin{array}{l}3.42 \\
1.55\end{array}$ & 1.42 \\
\hline $\begin{array}{l}5798 \\
5785 \\
\end{array}$ & $\begin{array}{l}440 \\
414 \\
\end{array}$ & $\begin{array}{l}1,69 \\
1,69\end{array}$ & $\begin{array}{l}77 \\
57\end{array}$ & $\begin{array}{r}130,13 \\
96,33 \\
\end{array}$ & $\begin{array}{r}10.73 \\
9.27 \\
\end{array}$ & $\begin{array}{r}.69 \\
.75 \\
\end{array}$ & $\begin{array}{r}.20 \\
-.16 \\
\end{array}$ & $\begin{array}{r}3.63 \\
3.03 \\
\end{array}$ & $\begin{array}{r}4.53 \\
3.24 \\
\end{array}$ & $\begin{array}{r}3.03 \\
2.24\end{array}$ \\
\hline 5742 & 358 & 1,70 & 49 & 83.30 & 11.28 & ,2? & .16 & 2.63 & 2.75 & 1.2 \\
\hline 5743 & 285 & $1,7 \pi$ & $\Leftrightarrow 4$ & 113.28 & 6.64 & .78 & .28 & 2.39 & 1.99 & .09 \\
\hline 5744 & 250 & 1,98 & 58 & 194,04 & $2+0.8$ & -.75 & -1.18 & 4.45 & 5.48 & $\frac{1.7:}{* * * t}$ \\
\hline 5745 & 353 & 1,69 & $6 ?$ & $104.7 \varepsilon$ & 8,83 & .53 & 119 & 0.00 & $2 * * *$ & $* *$ \\
\hline 5746 & 368 & 1.61 & 21 & 111,31 & 4,83 & & 1 & & & \\
\hline 5747 & 387 & 1.54 & 20 & 121,66 & 10,32 & 1,79 & .12 & 3.04 & 1.98 & 1.3 \\
\hline 5799 & $4 ? 1$ & 1,69 & $\varepsilon 6$ & 145,34 & 9.85 & .39 & 14 & 3.07 & 2.99 & 1.7 \\
\hline $\begin{array}{l}5749 \\
5793\end{array}$ & $\begin{array}{l}4644 \\
3114\end{array}$ & $\begin{array}{l}1,18 \\
1,87\end{array}$ & $\frac{29}{68}$ & $\begin{array}{l}1112,02 \\
167.16\end{array}$ & $\begin{array}{r}5.89 \\
8.03\end{array}$ & $\begin{array}{r}.42 \\
.47\end{array}$ & $\begin{array}{r}-20 \\
.23\end{array}$ & 3.49 & 3.08 & $-\frac{1}{1.2}$ \\
\hline 5751 & -486 & 1.86 & 22 & 50.22 & 13.53 & 70 & & $-2,86$ & 177 & \\
\hline 5752 & 428 & 2,07 & $1=9$ & 267,03 & 8.72 & 1.01 & .31 & 3.29 & 2.48 & 1,1 \\
\hline $\begin{array}{l}5753 \\
5754\end{array}$ & $\begin{array}{l}455 \\
417\end{array}$ & $\begin{array}{l}2,18 \\
1,62\end{array}$ & $\begin{array}{l}82 \\
83\end{array}$ & $\begin{array}{l}178.76 \\
134.46\end{array}$ & $\begin{array}{l}6.90 \\
4.33\end{array}$ & $\begin{array}{r}120 \\
1.25\end{array}$ & $\begin{array}{r}24 \\
112\end{array}$ & $\begin{array}{l}4.16 \\
3.00\end{array}$ & $\begin{array}{l}2.31 \\
2.57\end{array}$ & $\begin{array}{l}1.0 \\
1.6\end{array}$ \\
\hline $\begin{array}{r}5755 \\
-5756 \\
\end{array}$ & $\begin{array}{r}410 \\
-421\end{array}$ & $\begin{array}{l}1.91 \\
1.71\end{array}$ & $\begin{array}{l}517 \\
57\end{array}$ & $\begin{array}{r}171.90 \\
97.47\end{array}$ & $\begin{array}{l}5,56 \\
5,94\end{array}$ & $\begin{array}{r}1,71 \\
\quad .70 \\
\end{array}$ & $\begin{array}{r}30 \\
-17\end{array}$ & $\begin{array}{r}4.26 \\
3.35 \\
\end{array}$ & $\begin{array}{l}3.10 \\
2.62\end{array}$ & $\begin{array}{l}1,68 \\
1,22\end{array}$ \\
\hline 5757 & 350 & 1.83 & 6.7 & 162.01 & 9.13 & .47 & .14 & 3.20 & 3,22 & 1,1 \\
\hline 5758 & 397 & 1,81 & 56 & 101.36 & 5.78 & 1.25 & .22 & 3.41 & 2.62 & 1.4 \\
\hline
\end{tabular}


IUTERMERIATE UOSE

\begin{tabular}{|c|c|c|c|c|c|c|c|c|c|}
\hline An \# & VC & $\mathrm{TLC}_{\mathrm{d}}$ & $\mathrm{DLCO}_{\mathrm{Sb}}$ & $\mathrm{QSC}_{\mathrm{SS}}$ & $\mathrm{PEF}$ & EFR50 & EFR25 & $\mathrm{EFR}_{10}$ & $\triangle \mathrm{EFR}_{25}$ \\
\hline 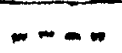 & $\cdots$ & $\ldots$ & 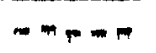 & $\cdots$ & $m-\infty$ & $m-m$ & $\operatorname{minmm}$ & $m-n=-$ & - \\
\hline 5701 & 9,50 & $11, \| 2$ & .210 & .64 & 110,4 & 110,0 & $7 Z, 2$ & 41.2 & 22,20 \\
\hline $\begin{array}{l}5702 \\
5703\end{array}$ & $\begin{array}{r}19.00 \\
9.25\end{array}$ & $\begin{array}{l}11,42 \\
10,15\end{array}$ & $\begin{array}{r}261 \\
233\end{array}$ & $\begin{array}{r}86 \\
.25\end{array}$ & $\begin{array}{l}103,0 \\
100,4\end{array}$ & $\begin{array}{l}9.7 \\
84.9\end{array}$ & $\begin{array}{l}38.0 \\
56.6\end{array}$ & $\begin{array}{r}25.7 \\
21.2\end{array}$ & $\begin{array}{l}-7,75 \\
14,15\end{array}$ \\
\hline 5798 & 11.50 & 14.53 & .335 & $\therefore .25$ & 115,0 & 108.1 & 74,6 & $\begin{array}{l}38,6 \\
32.2\end{array}$ & $\begin{array}{l}20,55 \\
13.55\end{array}$ \\
\hline 5742 & 0,25 & 9.50 & .209 & 1.00 & 110,7 & 100,4 & 57,9 & 30,9 & 7,70 \\
\hline $\begin{array}{l}5743 \\
5744\end{array}$ & $\begin{array}{l}9.00 \\
900\end{array}$ & $\begin{array}{r}9,99 \\
10,73\end{array}$ & .223 & $\begin{array}{r}.92 \\
.50\end{array}$ & $\begin{array}{r}110.7 \\
84.9 \\
\end{array}$ & $\begin{array}{r}97,8 \\
70,8\end{array}$ & $\begin{array}{l}67,6 \\
42,5\end{array}$ & $\begin{array}{l}28,3 \\
15,4\end{array}$ & $\begin{array}{r}18,70 \\
7,10\end{array}$ \\
\hline $\begin{array}{l}5745 \\
5746\end{array}$ & $\begin{array}{r}9.00 \\
3.25\end{array}$ & $\begin{array}{r}0.00 \\
10.20 \\
\end{array}$ & $\begin{array}{r}0.000 \\
-203 \\
\end{array}$ & $\begin{array}{r}.56 \\
.75 \\
-.75\end{array}$ & $\begin{array}{r}82.4 \\
110.0\end{array}$ & $\begin{array}{r}62,4 \\
105,5\end{array}$ & $\begin{array}{r}24,5 \\
68,2\end{array}$ & $\begin{array}{r}14.2 \\
30.2 \\
\end{array}$ & $\begin{array}{r}-6.70 \\
15.45\end{array}$ \\
\hline 5747 & 7.75 & 9.13 & .210 & .61 & 91,0 & 22.7 & 69,5 & 36,0 & 23,15 \\
\hline $\begin{array}{l}5799 \\
5749\end{array}$ & $\begin{array}{l}9.00 \\
2.50\end{array}$ & $\begin{array}{r}9.74 \\
11.52\end{array}$ & $\begin{array}{r}.232 \\
1.252\end{array}$ & $\begin{array}{r}.75 \\
.81\end{array}$ & $\begin{array}{r}100,1 \\
-100.4\end{array}$ & $\begin{array}{r}94.0 \\
1.00 .4\end{array}$ & $\begin{array}{r}55.0 \\
69.5\end{array}$ & $\begin{array}{l}34.7 \\
14.2\end{array}$ & $\begin{array}{r}8,00 \\
19,30 \\
\end{array}$ \\
\hline $\begin{array}{l}5793 \\
5751\end{array}$ & $\begin{array}{l}9.50 \\
0.40\end{array}$ & $\begin{array}{r}11.16 \\
10.40\end{array}$ & $\begin{array}{r}265 \\
+241 \\
\end{array}$ & $\begin{array}{r}.60 \\
-.72\end{array}$ & $\begin{array}{l}105.5 \\
115.8\end{array}$ & $\begin{array}{r}104,2 \\
106,8\end{array}$ & $\begin{array}{r}61,8 \\
64,4 \\
\end{array}$ & $\begin{array}{r}13.8 \\
19.3\end{array}$ & $\begin{array}{r}9,70 \\
11,00\end{array}$ \\
\hline 5752 & {$[i, 50$} & $\therefore, 61$ & .233 & .63 & 22,7 & 72.3 & 54,2 & 36,0 & 1.4 .80 \\
\hline $\begin{array}{l}5753 \\
5754\end{array}$ & $\begin{array}{l}9.25 \\
7.20\end{array}$ & $\begin{array}{r}10,31 \\
8,82\end{array}$ & $\begin{array}{r}.253 \\
.246\end{array}$ & $\begin{array}{r}97 \\
.50 \\
\end{array}$ & $\begin{array}{r}112.6 \\
65.2\end{array}$ & $\begin{array}{r}102.1 \\
85.6\end{array}$ & $\begin{array}{r}77,2 \\
-33,5\end{array}$ & $\begin{array}{r}55.3 \\
23.3\end{array}$ & $\begin{array}{r}23.15 \\
.70 \\
\end{array}$ \\
\hline $\begin{array}{r}5755 \\
5756\end{array}$ & $\begin{array}{r}8,88 \\
8,40\end{array}$ & $\begin{array}{r}10.56 \\
9.62\end{array}$ & $\begin{array}{r}260 \\
+240 \\
+24\end{array}$ & $\begin{array}{r}1.00 \\
-4.2\end{array}$ & $\begin{array}{r}-1.0 .0 \\
106.8\end{array}$ & $\begin{array}{r}0.0 \\
83.2\end{array}$ & $\begin{array}{r}0,0 \\
30,9 \\
\end{array}$ & $\begin{array}{l}0,0 \\
6,4\end{array}$ & $\begin{array}{r}0,00 \\
-10,25 \\
\end{array}$ \\
\hline 5757 & 2.13 & 10,85 & .278 & 1,30 & 74.6 & 65.5 & 12,2 & 2.6 & -19.90 \\
\hline 5758 & $9,1.2$ & 10,59 & .237 & .67 & 101.7 & 99,7 & 36.0 & 3.2 & $-1.3,85$ \\
\hline
\end{tabular}


HICH_DOSE

\begin{tabular}{|c|c|c|c|c|c|c|c|c|c|c|}
\hline An 非 & $\mathrm{HR}$ & $\mathrm{V}_{\mathrm{T}}$ & $\mathrm{f}$ & $\mathrm{V}_{\mathrm{E}}$ & $\Delta \mathrm{P}_{\mathrm{L}}$ & $\mathrm{R}_{\mathrm{L}}$ & $\mathrm{CDYN}_{\text {D }}$ & $\mathrm{FRC}_{\mathrm{d}}$ & $\mathrm{FRC}_{\mathrm{b}}$ & $\mathrm{RV}_{\mathrm{d}}$ \\
\hline$\cdots m$ & $\cdots$ & $\rightarrow$ & $\cdots$ & $m-\infty$ & $\cdots+\infty$ & $\cdots+$ & $m$ & $=n-$ & $=--$ & $\cdots$ \\
\hline 58 & -4120 & 2, & 45 & $-110,20$ & 9.9 .3 & 1.87 & $-1,28$ & & & 2.8 \\
\hline 58 & $4 \% 5$ & 8 & 52 & 110,76 & 14.13 & 1.56 & .13 & 4 & 3 & \\
\hline 58 & -4.46 & 2. & -4 & 91. & 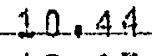 & 1,36 & .2 & & 3 & \\
\hline $\begin{array}{l}5843 \\
5845\end{array}$ & 400 & $1, ?$ & 31 & 59, & 12,83 & 2.49 &,$\frac{1}{3}$ & B & 6. & 4, \\
\hline & & & 6 & & & & & & & \\
\hline 58 & -414 & $2 x$ &  & $4 G, 2 E$ & 16 & -.8 & -.12 & & $2, B f_{2}$ & 6.5 \\
\hline 588 & 440 & $\therefore .6$ & .37 & 97.31 & 10. & .74 & .23 & 8 & 3.73 & 3,2 \\
\hline $\begin{array}{l}-588 \\
589\end{array}$ & 332 & $\begin{array}{l}1,-1.1 \\
2,16\end{array}$ & $\begin{array}{l}37 \\
.38\end{array}$ & $82,0 \varepsilon$ & $\frac{13}{5.40}$ & 2,03 & $\begin{array}{r}-4.45 \\
.35\end{array}$ & $\begin{array}{r}2.100 \\
4.85\end{array}$ & $\begin{array}{l}4,29 \\
5,02\end{array}$ & 3.5 \\
\hline & & & & & & & & & & \\
\hline
\end{tabular}

HIGH DOSE

\begin{tabular}{|c|c|c|c|c|c|c|c|c|c|}
\hline An 非 & $\mathrm{VC}$ & $\mathrm{TLC}_{\mathrm{d}}$ & $\mathrm{DLCO}_{\mathrm{sb}}$ & $\mathrm{QSC}_{\mathrm{sS}}$ & $\mathrm{PEF}$ & $\mathrm{EFR}_{50}$ & $\mathrm{EFR}_{25}$ & $\mathrm{EFR}_{10}$ & $\triangle \mathrm{EFR}_{25}$ \\
\hline 58 & & 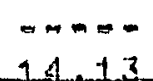 & $\Rightarrow \tan 0$ & $--\frac{-2}{83}$ & & $=\ldots$ & $\ldots-m=$ & $=-\frac{m}{5}=$ & $\begin{array}{ll}-7 .-5 . \\
-5,1\end{array}$ \\
\hline $\begin{array}{r}5818 \\
5842\end{array}$ & $\begin{array}{r}18.69 \\
6: 46\end{array}$ & $\begin{array}{l}15,41 \\
16,04\end{array}$ & $\begin{array}{r}1333 \\
+280 \\
\end{array}$ & $\begin{array}{r}1.25 \\
\quad .83 \\
\end{array}$ & $\begin{array}{r}104.2 \\
61.8\end{array}$ & $9 \%$. & $\begin{array}{l}61,8 \\
36,0\end{array}$ & $\begin{array}{r}12.9 \\
28,3\end{array}$ & \\
\hline $\begin{array}{r}5843 \\
5845\end{array}$ & $\begin{array}{r}11.30 \\
8.82\end{array}$ & $\begin{array}{r}16,06 \\
10,80\end{array}$ & $\begin{array}{r}1316 \\
-275 \\
\end{array}$ & .3 & $\begin{array}{l}77.2 \\
92.7\end{array}$ & $\begin{array}{r}47.5 \\
82.4\end{array}$ & $\begin{array}{r}10.3 \\
-42.6\end{array}$ & $\begin{array}{l}5,8 \\
7,1\end{array}$ & $\begin{array}{r}-13,50 \\
6,40 \\
\end{array}$ \\
\hline 5850 & 11,22 & 17,86 & -1522 & 67 & 1. & & 5,1 & -2.0 & $-21,25$ \\
\hline $\begin{array}{l}588 \mathrm{c} \\
5889\end{array}$ & $\begin{array}{l}12,25 \\
13,00\end{array}$ & $\begin{array}{r}15.48 \\
16.09\end{array}$ & $\begin{array}{r}.335 \\
-318\end{array}$ & 1,14 & $\begin{array}{r}86,9 \\
05,2\end{array}$ & $\begin{array}{r}5 \% \\
-20\end{array}$ & $\begin{array}{l}21,9 \\
51,5\end{array}$ & $\begin{array}{r}5,1 \\
18,0\end{array}$ & $\begin{array}{r}-4,50 \\
6,45\end{array}$ \\
\hline 5890 & 11.00 & 14,52 & .280 & .67 & $8 \%, 5$ & 74.6 & 25.7 & 2,6 & $-11,60$ \\
\hline
\end{tabular}




\section{APPENDIX F}

LUNG COMPOSITION DATA FOR INDIVIDUAL FISCHER 344 RATS 
CONTROL (0.0 pPm ACROLEIN)

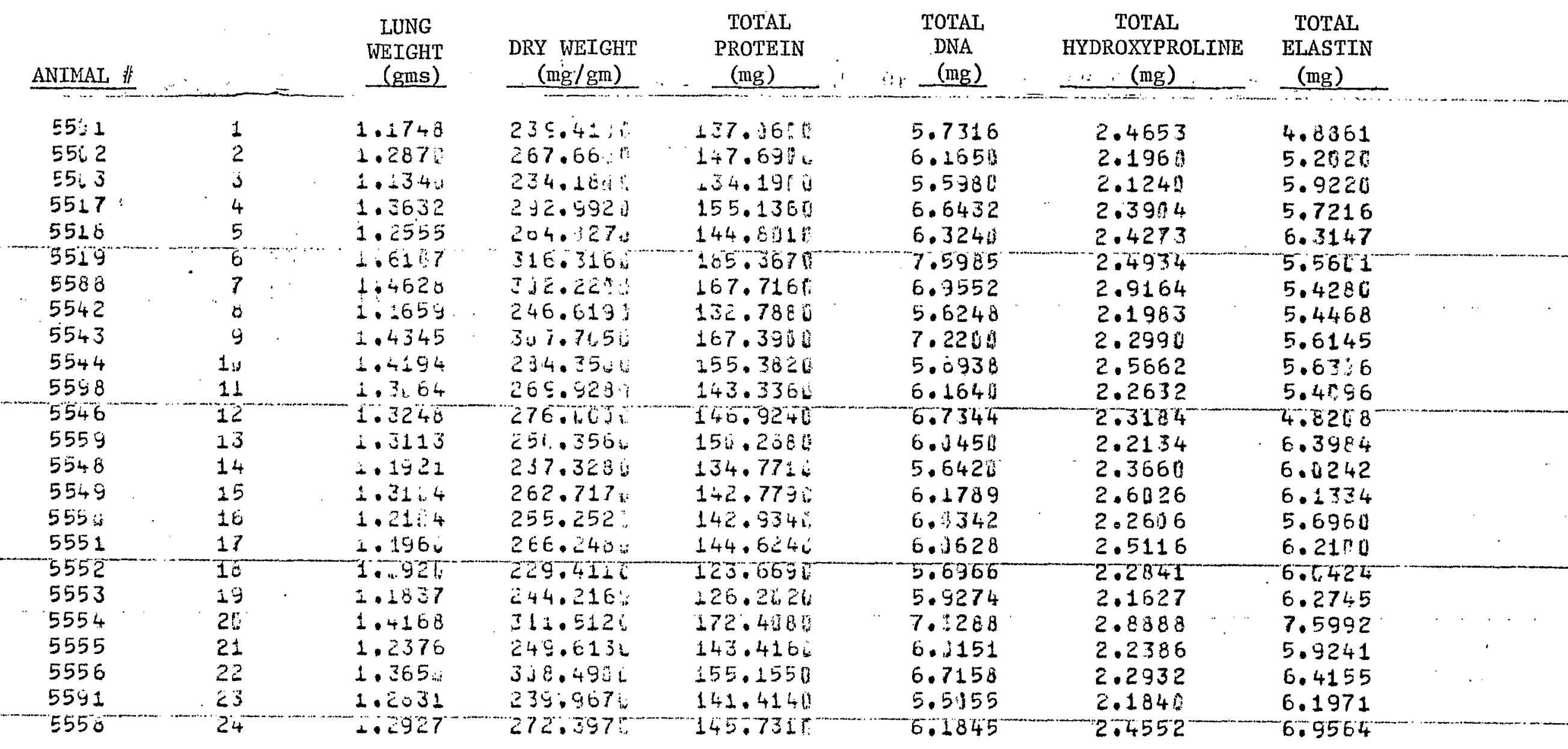




\section{$0.4 \mathrm{pPm}$ ACROLEIN}

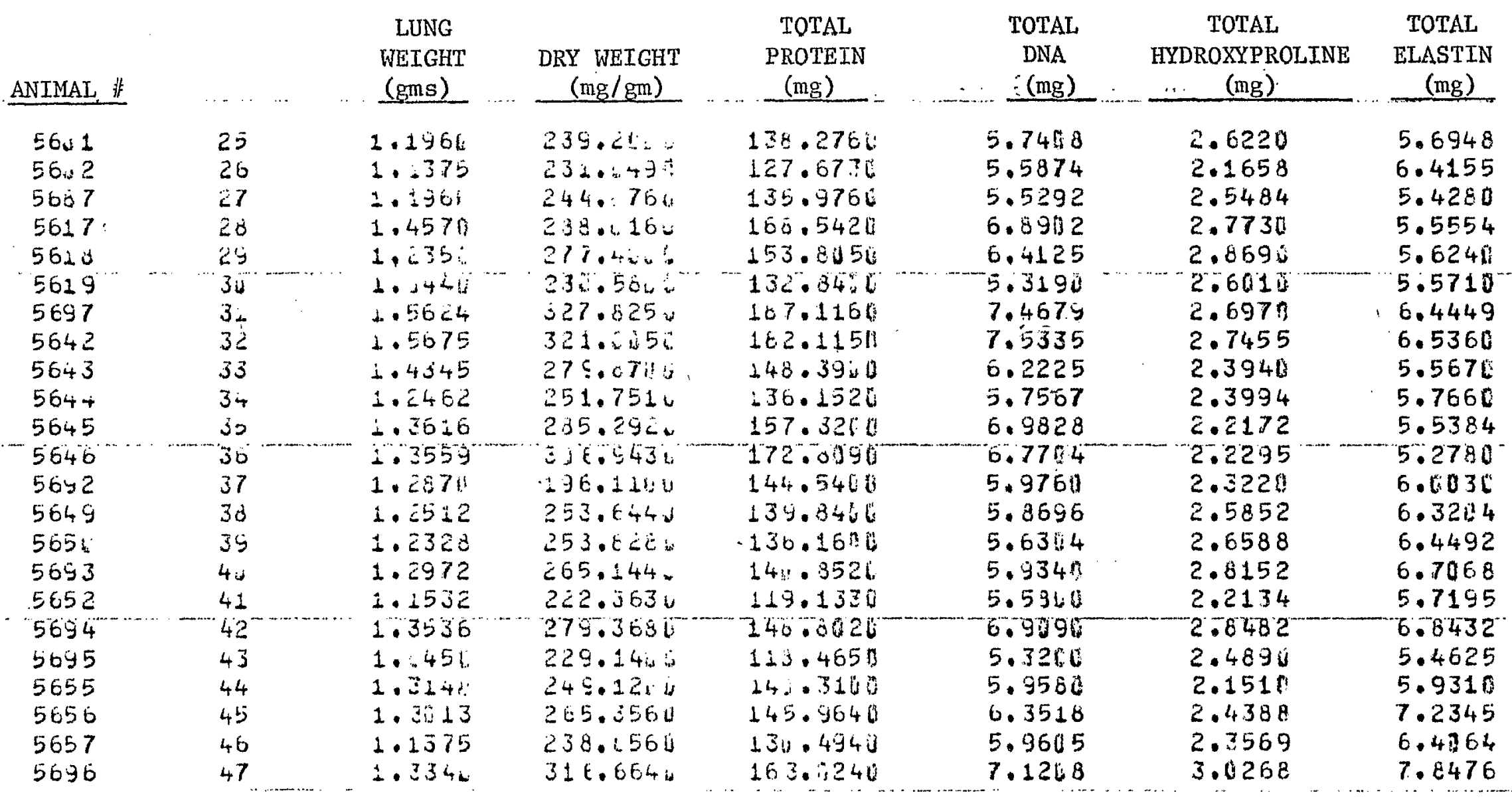


$1.4 \mathrm{ppm}$ ACROLEIN

ANIMAL \#

$\begin{array}{ll}57 i 2 & 48 \\ 5742 & 49 \\ 5743 & 5 \\ 5790 & 51 \\ 5785 & 58 \\ 5742 & 53 \\ 5743 & 54 \\ 5744 & 55 \\ 5745 & 56 \\ 5746 & 57 \\ 5747 & 50 \\ 5792 & 59 \\ 5749 & 65 \\ 5793 & 61 \\ 5751 & 56 \\ 5752 & 63 \\ 5753 & 64 \\ 5754 & 65 \\ 5755 & 66 \\ 5756 & 67 \\ 5757 & 60 \\ 5758 & 69\end{array}$

LUNG

WEIGHT DRY WEIGHT

(gms)

\section{TOTAL}

PROTEIN

$(\mathrm{mg} / \mathrm{gm})$

\subsection{5:}

$1 . .5559$

1. 2696

1.1645

1.17

1.3559

1. 335 i

1. 3442

1. 6461

1.9000

1.207

1.2760

1. 25.2

1. 314.

1.7340

1. 2044

1. 3.164

1.6916,

i. 2571

1. 3578

1. $\angle 4<\mathrm{B}$

1.2328
252.510 $275.912 \mathrm{~B}$

259.624

$229.841 \mathrm{u}$

$23 \mathrm{k} .85 \mathrm{I}$

273.96

$\therefore 70.28 \%$

272.5648

355.6310

3 马 E. 672

$248.761 \mathrm{~L}$

292.7680

245 . 53 :

252.278

$202.94 \%$

$231.336 \mathrm{~V}$

$231.64-1$

$238.49 \%$

258.533

271.6536

251.9085

$265.700 \%$
$+39.15:$ $\frac{(\mathrm{mg})}{-\cdots} \quad(\mathrm{mg})$

126.5416

157.1570

$: 56.320$

142.0350

142.2950

155.033

153.9950

153.140

$202.132 \mathrm{~L}$

221.3210

$137.9797 \mathrm{j}$

173.1446

133.435

149.9300

152.1766

$149.36 E 0$

177.5550

$145.359 \mathrm{i}$

142.6620

134.7800

$147.148 \mathrm{C}$
TOTAL HYDROXYPROLINE

(mg)

\begin{tabular}{|c|c|c|}
\hline $\begin{array}{l}5.6611 \\
6.5975 \\
5.7516 \\
5.2870 \\
5.4540 \\
6.5365 \\
6.5430 \\
6.2886 \\
7.7283 \\
7.1520 \\
5.9850 \\
6.7252 \\
6.3920 \\
6.398 \\
6.1100 \\
6.0376 \\
6.2744 \\
6.41230 \\
5.8032 \\
6.3541 \\
5.8604 \\
5.8420\end{array}$ & $\begin{array}{l}2.5650 \\
2.6754 \\
2.9256 \\
2.6354 \\
2.7631 \\
2.6218 \\
2.5380 \\
3.0174 \\
3.1341 \\
3.0720 \\
2.5110 \\
3.2292 \\
2.6794 \\
2.637 \\
3.2994 \\
2.8796 \\
3.1372 \\
2.7775 \\
2.4831 \\
2.7528 \\
2.6036 \\
3.5544\end{array}$ & $\begin{array}{l}5.1390 \\
6.2972 \\
6.11076 \\
5.5081 \\
6.1290 \\
5.6966 \\
5.7426 \\
7.3226 \\
6.1287 \\
5.8464 \\
6.1650 \\
8.1328 \\
6.8150 \\
5.9220 \\
8.3284 \\
6.9460 \\
7.1310 \\
6.1275 \\
6.4170 \\
6.2124 \\
6.4032 \\
6.9460\end{array}$ \\
\hline
\end{tabular}

TOTAL

ELASTIN

(mg) 


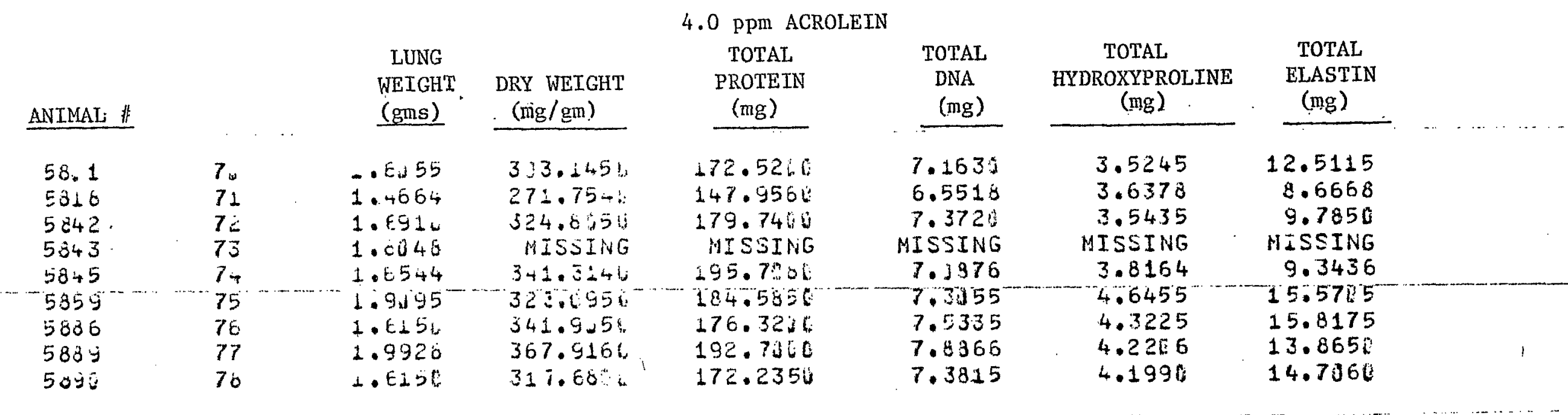


APPENDIX G

ABNORMAL SPERM DATA FROM INDIVIDUAL RATS 
Percent Abnormal Sperm from Fischer 344 Rats Exposed to Filtered Air, 0.4, 1.4, or $4.0 \mathrm{ppm}$ Acrolein

Acrolein

Concentration (ppm)

0.0

0.0

0.4

1.4

4.0
Anima1

Number

5501

5502

5503

5504

5506

5517

5519

5542

5584

5588

5602

5607

5608

5617

5619

5642

5645

5687

5697

5701

5702

5703

5704

5745

5746

5747

5785

5786

5798

5805

5806

5808

5818

5820

5823

5842

5845

5859

5884

\begin{tabular}{|c|c|c|}
\hline & $\begin{array}{l}\text { Raw } \\
\text { Data }\end{array}$ & $\arcsin \sqrt{\mathrm{p}}$ \\
\hline $\operatorname{mean}\left(t_{\text {s.e. }}\right)$ & $\begin{array}{l}1.0 \\
1.0 \\
4.2 \\
1.0 \\
1.4 \\
1.8 \\
1.0 \\
2.0 \\
2.6 \\
\frac{2.2}{1.8(0.36)}\end{array}$ & $\begin{array}{r}5.74 \\
5.74 \\
11.83 \\
5.74 \\
6.80 \\
7.71 \\
5.74 \\
8.13 \\
9.28 \\
8.53 \\
7.52(0.706)\end{array}$ \\
\hline mean (ts.e.) & $\begin{array}{l}0.4 \\
0.8 \\
9.0 \\
1.4 \\
4.0 \\
2.2 \\
1.6 \\
1.6 \\
2.0 \\
2.6(0.98)\end{array}$ & $\begin{array}{r}3.63 \\
5.13 \\
17.46 \\
6.80 \\
11.54 \\
8.53 \\
7.27 \\
7.27 \\
8.13 \\
8.42(1.515)\end{array}$ \\
\hline mean (ts.e.) & $\begin{array}{l}1.6 \\
1.0 \\
0.8 \\
2.0 \\
2.0 \\
1.4 \\
1.4 \\
3.2 \\
3.6 \\
1.0 \\
1.8(0.33)\end{array}$ & $\begin{array}{r}7.27 \\
5.74 \\
5.13 \\
8.13 \\
8.13 \\
6.78 \\
6.78 \\
10.30 \\
10.94 \\
5.74 \\
7.49(2.030)\end{array}$ \\
\hline mean $( \pm s . e)$. & $\begin{array}{l}0.6 \\
2.4 \\
1.0 \\
3.2 \\
7.2 \\
3.8 \\
3.6 \\
2.0 \\
3.4 \\
1.6 \\
2.9(0.66)\end{array}$ & $\begin{array}{r}4.44 \\
8.91 \\
5.74 \\
10.30 \\
15.56 \\
11.24 \\
10.94 \\
8.13 \\
10.63 \\
\frac{7.27}{9.32(1.113)}\end{array}$ \\
\hline
\end{tabular}


APPENDIX H

CANONICAL ANALYSIS PLOTS OF PULMONARY DATA FROM FISCHER 344 RATS EXPOSED TO ACROLEIN 
Canonical analysis plots of Fischer 344 rats exposed to either $0.0(+), 0.4(0), 1.4(\bullet)$, or $4.0(0)$ ppm acrolein, the centroids of each group are indicated by $1,2,3$, or 4, respectively. The canonical variables are based on both respiratory physiology and lung composition parameters.

Page I-2

$0.0,0.4,1.4$, and $4.0 \mathrm{ppm}$ exposure groups

Page $I-3$

$0.0,0.4$, and $1.4 \mathrm{ppm}$ exposure groups 


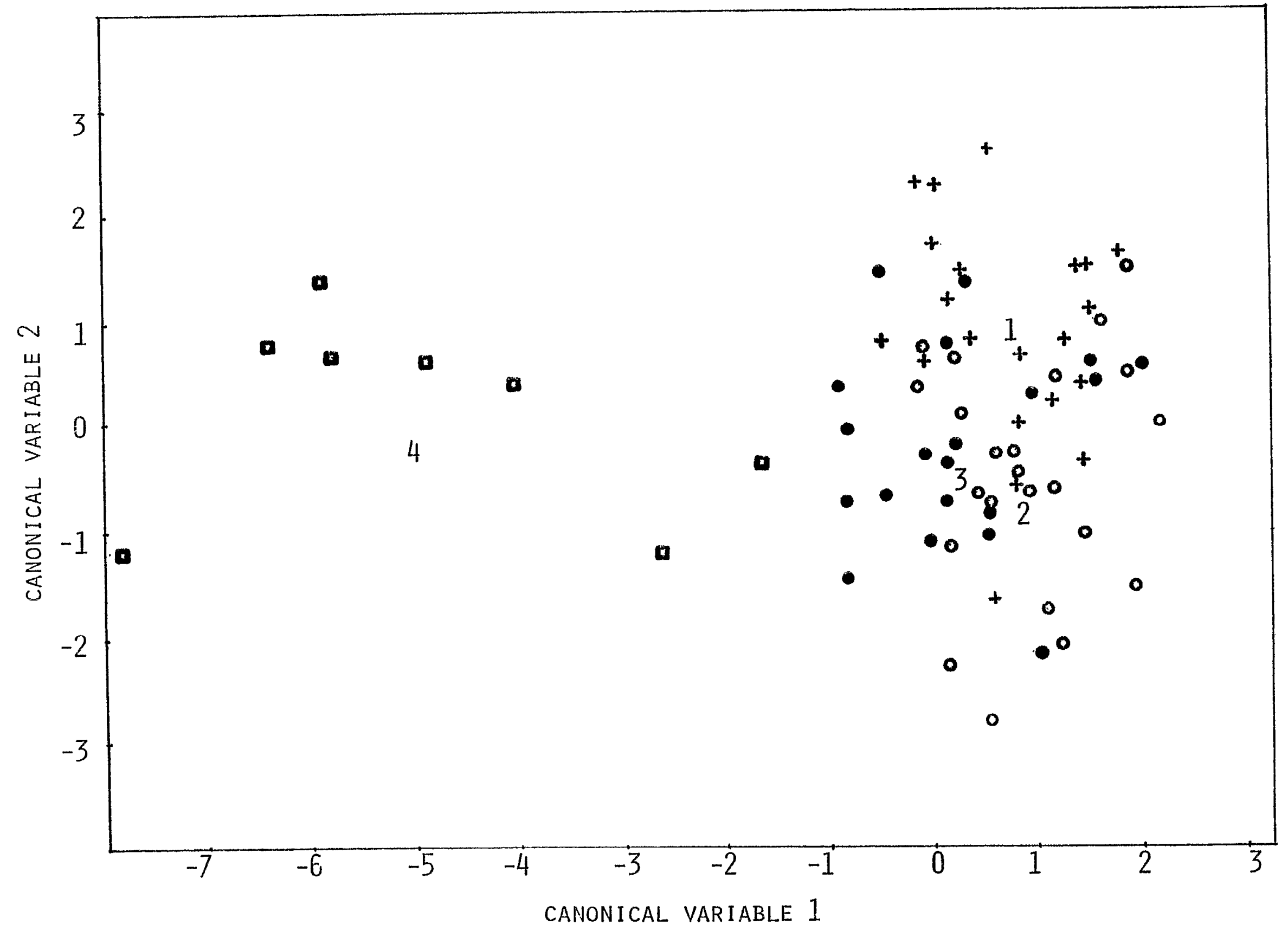




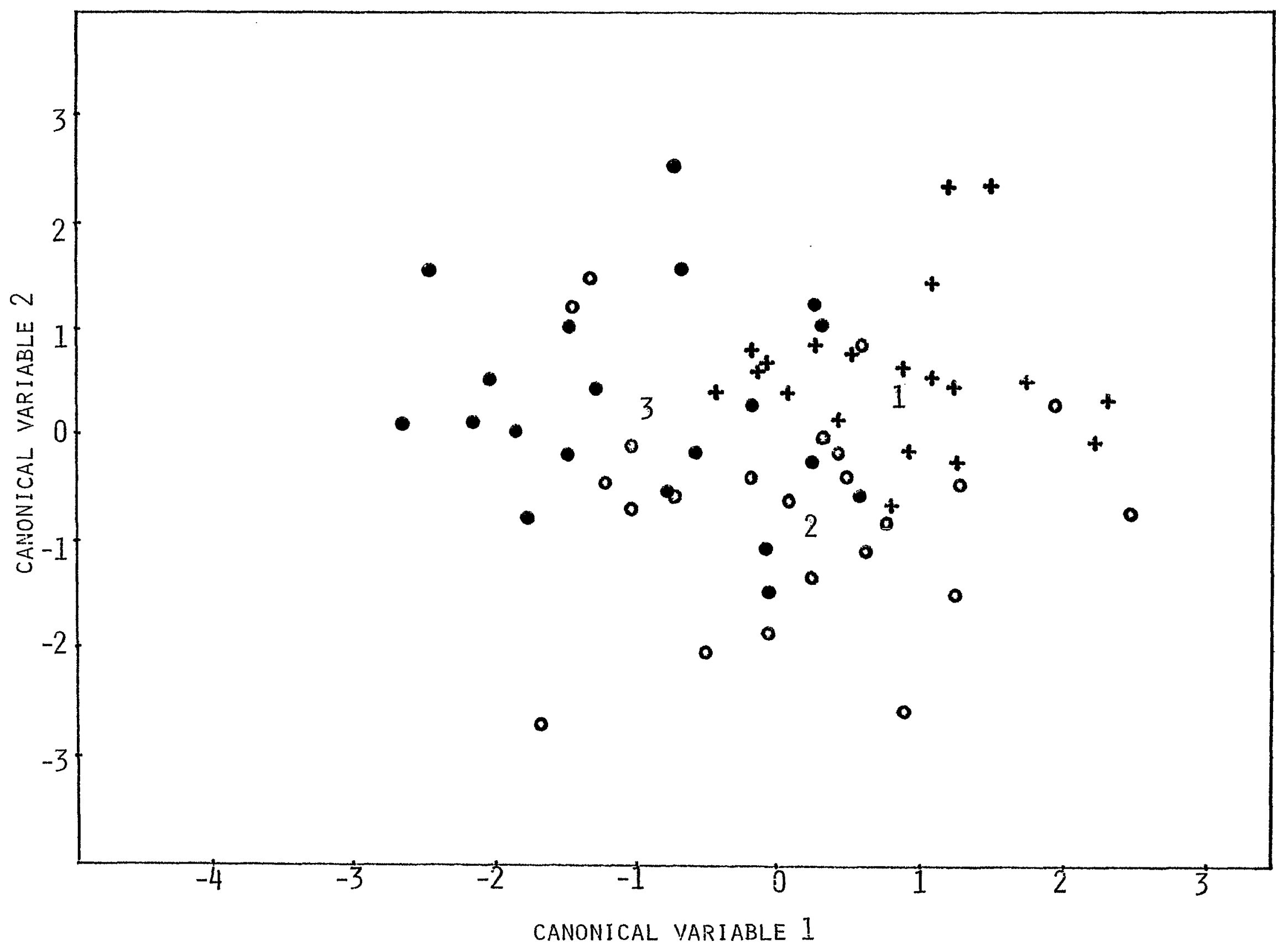




\section{APPENDIX I \\ FOLLOW-UP PULMONARY HISTOPATHOLOGY ON RATS MAINTAINED UNDER NON-SPF CONDITIONS FOR TEN WEEKS AFTER SIX DAY POST-EXPOSURE RECOVERY PERIOD}




\section{BROOKHAVEN NATIONAL LABORATORY \\ $M E M O R A N D U M$}

DATE: $\quad$ March 13, 1981

TO: R. T. Drew and R. S. Kutzman

FROM:

R. W. Wehner DVWW

SUBJECT: Pulmonary pathology of Fischer 344 rats following acrolein exposure and ten week maintenance on room air.

The attached report describes the findings of the microscopic examination of the exposed rats. The high dose group displayed changes associated with a wide range of insults, but little that could be directly related to the toxicant exposure. The role of acrolein in these animals may simply be one of aggrevating pre-existent pathologic entities.

The subtle morphologic alteration of cardiac anatomy is thought to represent processes associated with aging and spontaneous disease.

jc

Attachment 
Control Animals (\#5527, 5531, 5529, 5530,5532, 5525)

HGE stained slides of transverse biventricular heart sections failed to disclose specific pathologic change. Neither myocardial fiber hypertrophy nor necrosis was recognized. Increased leukocytic (Iymphocytic) populations between fibers seen in two of the six control rats were thought characteristic of lowgrade chronic murine myocarditis. Similar lymphocytic hypercellularity, in two other heart sections, was uniformly perivascular in location and thought associated with natural aging processes.

Three of the six control lungs examined microscopically were normal. Two of six animals displayed small compact collections of sloughed airway epithelium within alveolar lumina. The pathophysiologic events leading to focal partial detachment of airway epithelium is unclear. Sections of lung from one animal displayed prominent Iymphoid tissue, both the BALT and peripheral aggregates, possibly indicative of prior challenge. Medical calcification of medium sized arteries was additionally found in the same rat (\#5530) and in all likelihood would represent a phenomenon associated with aging.

Low Dose Animals (0.4 ppm acrolein) (\#5625,5626,5630, 5632).

Sections of cardiac ventricles were similar to control animals in appearance. The low grade chronic myocarditis was no more severe than that recognized in the control group.

Pulmonary parenchyma in these animals was essentially normal excepting modest 1ymphoid hyperplasia in two rats $(5626,5630)$ and sma11 aggregates of sloughed epithelium. Neither of these changes can logically be solely attributed to the toxicant exposure.

Intermediate Dose Animals (1.4 ppm) (\#5732, 5797, 5730, 5727, 5725).

Sections of heart were similar to control and low dose animals. Frank myocardial fiber hypertrophy, necrosis, or thrombosis was not recognized in any of the sections.

Likewise the pulmonary morphology was essentially normal. Although focal medial calcification, and small intraalveolar collections of sloughed epithelium were seen, changes considered toxicant related were not readily recognized. 
High Dose Animals $(4.0 \mathrm{ppm})(\# 5825,5826,5036$, no tag).

Sections of heart from the rats exposed to the high dose of acrolein were similar in appearance to the other three groups, i.e. no toxicant specific lesion or tissue alteration was noted. The changes present, chronic murine myocarditis and perivascular 1ymphocytic hypercellularity were thought related to aging processes.

The sections of lung examined from this group of animals displayed a consistent pattern of pulmonary injury. The clustering of foamy, sometimes pigmented, intraalveolar macrophages was always attended by a mononuclear intraseptal hypercellularity, the two changes mutually resembling low grade interstitial pneumonitis. Moreover, this change was usually found in a subpleural location, that most often associated with chronic murine interstitial pneumonia. Inflammatory cells suspended in mucus within airway lumina were found in two animals and may well represent residual low grade subacute bronchitis. No proliferative epithelial changes were recognized in any of the sections. The presence of interstitial pneumonia, clustering of macrophages, and even mild subacute bronchitis are not specific injuries following the insult of acrolein inhalation. The limitation of these changes to the high dose group, however, suggests an obvious association with the toxicant exposure, possibly as an agitator of pre-existing, naturally occurring pathologic entities. 